\title{
VOCABULARIES FROM THE MIDDLE OF THE 20тн CENTURY FROM AFGHANISTAN
}

\author{
PART TWO: ÖZBEK AND MOGHOL MATERIALS*
}

\section{Collected by A. F. MACKENZIE, edited and explained by VOLKER RYBATZKI}

\author{
VOLKER RYBATZKI \\ Section for East Asian and Altaic Studies, Department for World Cultures, University of Helsinki \\ FIN-00014 University of Helsinki, Finland \\ e-mail: volker.rybatzki@helsinki.fi
}

In addition to the references to Mackenzie mentioned in the first part of this paper, I found another one in Schurmann (1962, p. 13) that reads as follows: "In the late 1940s, an American named Mackenzie, then teaching in Kabul, was reputed to have come across some Mongol settlements in the Turkestan region. He made some photographs and compiled a small vocabulary. However, although he communicated his discovery to a number of scholars, none of his material has been published, to my knowledge." This statement is also cited in Doerfer $(1971$, p. 228). It is to be hoped that this series of papers might lead to the discovery of Mackenzie's photographs. Their localisation would be of indispensible importance for the ethnography, history and culture of the Turkic, Hazara and Moghol people of the northern part of Afghanistan. After writing this short introduction in the middle of 2014, the work had to be put aside due to other obligations. Not much new can now, after about four years, be said about A. F. Mackenzie. His second name was Franklin as it is stated by Dupree (1973, p. 74) who knew Mackenzie from their common time in Afghanistan where both seem to have worked for or been in contact with an American organisation called Meridian ${ }^{1}$.

\section{(v) Analysis of the Özbek Vocabulary}

The Özbek material collected by Mackenzie represents the lingua franca of Northern Afghanistan, Afghan Turkestan as it was called at that time. It is not clear, but prob-

* The first part of this paper, containing the Persian, Nuristani and Dardic materials, was published in $A O H$ in Vol. 66, No. 3, pp. 297-348 (Persian), and Vol. 66, No. 4, pp. 443-469 (Nuristani and Dardic).

${ }^{1}$ Cf. www.meridian.org/insmallthingsremembered/the-first-american-expedition-to-afghanistan 
able, weather the area of this lingua franca extended also further eastwards up to the western regions of Eastern/Chinese Turkestan (nowadays Xinjiang). In order to get an idea about the particularities of the vocabulary, I gave it for examination to Dr. Sabohat Hashimova, an Özbek teaching Özbek and Russian at Minzu University in 2013-2014, and Dr. Dilaram Veli, one of my Uyghur students at the same university. The conclusions of both of them were more or less the same. There are a number of words not common to, or not found in, Özbek. Furthermore, the vocabulary was considered old-fashioned, phonologically not always corresponding to "Standard Özbek", cf. for this statement also Jarring (Ja37, pp. 5-20). The verbal forms given by Mackenzie as infinitives are mostly present or past tense forms.

(32, xxviii) Özb. aba [Haz. abgha] 'uncle (father's brother)' - $\mathrm{Mgh} / \mathrm{L}_{2} a b \bar{a} n \bar{a}$ [Ar.] 'unser Vater' (W77, p. 110) - cf. Haz. vocabulary under abgha 'id.' and $a b a$ 'mother'; Badghisi 1960, p. 34; MYYC p. 90; M38, p. 61*; Sevortjan i, pp. 57-58; TMEN §412; VEWT p. 1 (ursprünglich Lallwort) $\bullet$ Pe. $\bar{a} b \sim[\mathrm{Ar}] a. b \sim$ [Ar.] $a b \bar{u}$ 'father' (St pp. 3, 11); Taj. $a b$ (lit.) 'father, ancestor' (Mir06, p. 23; $\rightarrow$ ), abu/l [Pe.] 'father (with proper names); owner, holder' (id. p. 24); Dari $a b$ $\sim a \hat{b} \hat{a}$ 'Vater' (KiMi78, p. 20); Pšt. $a b$ [Ar.] $a b \bar{a}$ [Ar.] 'father [отец, батюшка]' (As85, p. 19) $\sim a b$ [Ar.] 'father, master, possessor' $\sim a b \bar{a}$ 'a word of endearment to a father' (Rav67, pp. 1, 2); Urd. $a b$ [Ar.] 'father (rare)' $\sim a b b \bar{a}$ [Hi.] 'father, superior; a consummate knave' $\sim a b \bar{u}$ [Ar.] '(used, like ibn, in combination with a following substantive in the genitive, the final $\bar{u}$ being shortened in pronouns if the Ar. article precede the substantive) father, originator, author etc.' (Pl pp. 1, 2, 5) • Tu. (VIII) aba apa äbä äpä words of this form, connoting various terms of relationship abound in modern Tu. languages with meanings as various as (1) 'ancestor', (2) 'grandfather', (3) 'grandmother', (4) 'father', (5) 'mother', (6) 'paternal uncle', (7) 'paternal aunt', (8) 'elder brother', (9) 'elder sister', (10) (presumably metaph.) 'midwife'; some, e.g. aba 'paternal uncle', an abbreviation of Mo. abara, and other words beginning with $a b^{\circ}$ etc. are certainly foreign; others, often occurring in only one language group, are of unknown origin. The only early forms seem to be (VIII) apa 'ancestor and (XI/Oghuz) $a ̈ b \ddot{a}$ 'mother'. In this early period it is often impossible to be sure whether the vowels are back or front and the consonant voiced or unvoiced (C72, p. 5). Differently Röhrborn states "Uig. apa 'Großvater, Vorfahre männl. Geschlechts'; das Wort ist nur auf männl. Personen bezogen, steht also nicht für äbä' (Rö p. 167) - Trkm. aba (i) 'father, dad/dy', (ii) n. pr.' (BaKaXa68, p. 15); Kir. ' $a b a$ 'Onkel; Anrede an einen älteren; älterer Bruder' (Ju p. 17) < Mo. > Özb. > Taj. avå ävå 'Vatersbruder', fehlt bei Bor59 [und CAHG], aus özb. Lokaldialekten aber schon Cag. belegt (Do67, p. 9); prob. not Mo. > Özb., but Mo. > Kir. > Özb. as there seem to be no direct 1.-w.s from Mo. in Özb.; Trki a:ba: [Ar.] 'fathers, ancestors' (Ja64, p. 10) vs. abu [Ar.] 'father' (Ja80, p. 119); Lop. ava 'father, ancestor' (more common: ata) (Mal56, p. 79); $\mathrm{Sal} / \mathrm{Ili}$ aba 'father' [OTu. aba] (Ya02, p. 31), /Qh $a b a \sim a \beta a \sim a \beta \partial: \sim a \beta i \sim$ $a b \partial:$ a o 'father' $\approx a v a$ 'id.', (folk.) avan avay 'elder relative' (Kak62, 
p. 175; Ten76b, pp. 279, 297), forms with $-v-<$ Mo.; YogW ava 'father (in songs)' - Mo. (Mal57, p. 11) awa - Tu. 'id' (Ro00, p. 287), avan avay 'elder relative [старший родственник]', avana $(\leftarrow$ ava + ana $)$ 'older relatives [старшие родственники]' (Ma157 id., Ten76a, p. 174) • MMo. Ø; MoL abu $a b a$, KhalL $a w \sim a a w$ 'father, grandfather, esp. applied to an old father (endearing)' (Le60, p. 5); Ord. $\bar{a} w u$ 'grand-père, père [surtout lorsqu'il est âgé]; terme de repect dont on se sert pour adresser la parol à in vieillard, ou pour parler de lui' (Mos41, p. 37); Kalm. $\bar{a} w^{B}$ 'Vater, Papa; (so nennen die Kinder und Hausgenossen den Vater)', cf. $b \bar{a} w^{B}$ (Ra35, p. 21); YogE $a \beta a$ 'father' (Ro00 id.) - Etymologically unclear. Structurally the Özb. word could be of Ar.-Pe., Tu. or Mo. origin, semantically only of Mo., the meaning is attested in Kir. that should be thus considered the origin of the Özb. word.

(30, xxvi) Özb. ana [Haz. aba] 'mother' - Özb/Afgh. ana a:na ena ina 'mother', katta ina ine 'grandmother' (Ja38, p. 172; $\rightarrow$ ) - Badghisi 1960, pp. 39, 224-225; M38, p. 38*; Ry06, pp. 126-127; Sevortjan i, pp. 278-281; TMEN §567; VEWT p. 19 - Pe. an 'mother' (St p. 102); Taj. åna 'mama, mother; grandmother' [ $<$ Özb.], ånakalån 'grandmother, great-grandmother' (Mir06, p. 449; $\rightarrow$ ); Srq. anâ [Tu.], Wx. nân 'mother' (Pa75, p. 226, Sh76, p. 96) nan 'mother, mama' (St-Ka99, pp. 242-243); Pšt. an $\bar{a} \sim$ nīa 'grandmother', Pšt/Waz. niō $\sim$ Pšt/Dial. uyā etc.; prob. anā is a children's word, cf. Srq., Trki ana 'mother', Latin anus, Old High German ana 'grandmother' etc. (M27, p. 10; M03, p. 8) Pšt. ana 'grandmother' (As85, p. 76) anā 'id.' (Rav67, p. 50) - Uig. (VIIIff) ana 'mother'. Like ata, first appears in Uig., where it is still rare and $\ddot{g} g$ still common. C.i.a.m.l.g., except NE where it has been partially displaced by Mo. ece $\sim$ ice; sometimes subjected to unusual deformations, e.g. anne, to make it a term of more intimate affection (C72, pp. 169-170) - Tr. ana 'mother (the form anne is preferred in Istanbul); mother animal, dam; appellation of respect for elderly women or female saints (used after the name); etc.' (Red p. 35); Trkm. äne 'grandmother; mother; maternal' (BaKaXa68, p. 789); Kzx. ana 'mother', ana tili 'native language' $\rightarrow$ analiq 'motherhood, maternity' (Shn66, p. 22); Kir. ${ }^{2}$ ana äne 'eldery woman; old (of females)' (Ju p. 56); Özb/Buch. ana åna 'mother', kata åna 'grandmother', ata åna 'parents' (O05, pp. 6, 7), /Qil. ana 'mother', katta ana 'grandmother', ata ana 'parents' (Ja37, pp. 46, 47), Özb. åna (formal) 'mother, form of address for older woman' ena (dial.) 'mother' (CAHG pp. 208, 81; Bor59, pp. 304, 555), Özb. > Taj. åna 'Großmutter (in der Rede einiger Vertreter der alten Intelligenzschicht)' (Do67, p. 27); Trki. ana an'a 'mother' (Ja64, p. 22; Ja67, p. 9; Ja87, p. 31; Ja96, p. 38), anaka ancka (Guma) 'mother, little mother', anckam (Guma) 'grandmother' (Ja64, Ja67 id.), ata a. 'parents' (Ja80, p. 120; Ja87 id.); Uy . ana 'mother; female', a. tili 'mother tongue, native language', a. yurti 'birthplace, native place, hometown', a. härä 'queen-bee', ana-bala 'mother and child' (Sch92, pp. 49-50); Lop. ana 'mother', čoy a. 'grandmother' (Mal56, p. 85); Sal/Ili ana 'girl', anagu 'young girl' [ $\leftarrow$ ana + Ch. 姑 $g u$ ] (Ya02, p. 41), /Qh ${ }^{1}$ ana āna 'girl, maiden [Ru. девушка]' (Kak62, 
p. 175; Ten76b, p. 288); YogW ana 'mother, stepmother', anaqïm ( $\leftarrow$ ana + qaï $+m$ ) 'my mother', anay 'mother (my)', cf. 'ačay (Mal57, p. 15; Ten76a, p. 172), ana 'mother' $\rightarrow$ anika ( ayka) 'grandmother, old woman', ača-ana ačana ačaana 'parents', pezïk (pezïk $)$ ana 'aunt (father's elder brother's wife)' (Ro00, pp. 279, 282) • Tu. > Mo. (TMEN id.) - MMoU, A ana [Cag. ana] 'mother' (Rybatzki, forthcoming b); Mgr. ani 'id.' (Smedt-Mostaert 1933, p. 8); YogE ana 'id.' (NuRo96, pp. 393,4; 50 0 ).

(21, xixA) Özb. at [Haz. boda] 'horse' - Özb/Afgh. at a:t 'id.' (Ja38, p. 174; $\rightarrow$ ); $\mathrm{Mgh} / \mathrm{Bdx}$. at [Pe. asb] 'id.' (HeHiThe79, p. 20094); Afš/Kbl hat at 'id.' (DoHe89, p. 49); Trkm/Afgh. āt, Ar. hail, Mgh. murīn, Pšt. as (sic), Pe. asp 'id.' (W73, pp. 506 $63: 3,516)$ - cf. Pe. vocabulary under asp, and ( $\downarrow)$ Mgh. vocabulary under morin; Eren 1999, p. 24; Hauenschild 1998, p. 31; 2003, pp. 29-39; 2006, pp. 69-73; 2008, pp. 10-11 [Yak. ${ }^{1-4}{ }^{a t}$ "'Pferd; ${ }^{2}$ Wallach; ${ }^{3}$ Esel; ${ }^{4}$ kastriertes Männchen]; M38, p. 30*; Sevortjan i, pp. 197-198; TMEN $\S 413$; VEWT p. 30 • Tu. (VIII) at 'horse'; nearly always with the implication of 'riding horse'; in a few modern languages at means 'gelding', as opposed to adyï 'stallion'. C.i.a.p.a.l. (C72, p. 33) - Tr. at 'horse' (Red p. 51); Khlj. ha.t hat 'id.' (DoTe80, p. 127); Trkm. at 'id.' (BaKaXa68, p. 55); Kzx. 'at 'horse (of any kind, or, specifically, a gelding)' (Shn66, pp. 28-29); Kir. at 'horse' (Ju p. 77); Özb/Buch. āt 'id.', àt ğalap 'horse dealer' (O05, p. 7), /Qil. at 'id.', su at [Pe. asp-i abi] 'water-horse' (Ja37, p. 39:3), Özb. 'at 'horse; knight (in chess)' (CAHG p. 213; Bor59, p. 308); Trki ${ }^{2} a t \sim a \cdot t \sim a: t$ 'horse', ayï a. 'stallion', aymaq a. 'kind of horse, trotter', java a. 'wild horse', a. jukki 'horseload' (Ja64, p. 29) ' $\bar{a} \underline{\underline{t}} \sim a \underline{\underline{t}}$ 'Pferd, Ross', āt ulá $\gamma$ 'Rosse und Lastpferde' (Ja67, p. 11) at a:t 'horse' (Ja80, p. 120); Uyy. 'at 'horse (Equidae)' $\rightarrow$ atči 'hired horsecart driver; horsedealer' $\rightarrow$ atčiliq 'horse trade (literal)', $\rightarrow$ atxana 'horse stable', also at qurisi, $\rightarrow$ at-ulaq 'draft animals, beasts of burden', $\rightarrow$ atlan- 'to mount (a horse)', $\rightarrow{ }^{1}$ atliq 'on horseback, with horse; (hist.) knight, cavalier', $\rightarrow$ atnali 'horseshoe', also 'taqa (Sch92, pp. 3, 6, 7); Trki/Ili 'at 'horse' (Ha91, p. 37); Lop. ' at 'id.' (Mal56, p. 87); Sal/Ili at 'id.' (Ya02, p. 47), /Qh ${ }^{2} a t \sim a c \sim a c$ ' $\sim{ }^{2} \bar{a} t \sim a 3^{\prime}$ 'id.' (Kak62, p. 176; Ten76b, p. 295); YogW at 'id.' (Ma157, p. 19), a't hat $\sim \chi a t^{\prime}$ 'id.' (Ten76a, p. 173), $a^{h} t \sim a^{h} t^{h} \sim h a t^{h} \sim$ $\chi a t$ 'id.' $\rightarrow a^{h} t \check{c} \ddot{i} \sim a^{h} t^{h} c \grave{c} \ddot{\text { etc. }}$ 'horseherd' (Ro00, p. 287).

(31, xxvii) Özb. ata [Haz. ata] 'father' |Cf. Hazarāgī vocabulary

(34, xxxiv) Özb. ayagh [Haz. kari] 'shinbone' - Özb/Afgh. aya 'foot, leg' (Ja38, p. $170 ; \rightarrow) ;$ Mgh/Bdx. ayay [Pe. pā] 'Fuß' (HeHiThe79, p. 19969) - Eren 1999, p. 26; MYYC p. 93; M38, p. 50*; Sevortjan i, pp. 103-104; TMEN §1972; VEWT p. 5 - Tu. (VIII) adaq originally rather indefinitely 'leg, foot'; in some contexts one meaning seems to be required to the exclusion of the other, in others vice versa. Became a l.-w. in Mo. as adaq, but apparently only in the metaph. meanings 'the foot (of a mountain); the end, or mouth (of a river); end, final'. S.i.a.m.l.g., usually as ayaq or the like, in its original meaning; but in some languages adaq was reborrowed from Mo. with the meanings current in that language (C72, p. 45) - Tr. ayak 'foot; leg; base, pedestral, footing; etc.' 
(Red pp. 56-57); Khlj. hada:q hadaq 'Fuß' (DoTe80, p. 123); Trkm. ayak 'foot, leg' (BaKaXa68, p. 61); Kzx. ayaq 'foot, leg; end, consequence, result; last, latter' (Shn66, p. 34); Kir. ayak 'foot, leg; lower part of the leg; end, bottom; etc.' (Ju p. 86); Özb/Buch. ayak 'foot' (O05, p. 4), /Qil. ayay 'id.' (Ja37, p. 46), /Urg. ayaq 'foot', ayaqüm 'my foot' (Dob74, p. 85), Özb. '̊̊å̊q 'leg, foot; end, limit, far end; place in the room closest to the door (i.e. farthest from the place of honour)' (CAHG p. 215; Bor59, pp. 296-297); Trki ${ }^{1}$ ayay ayaq 'foot, leg; the East', a. tam 'north, northern', igin a. 'clothes' (Ja64, p.

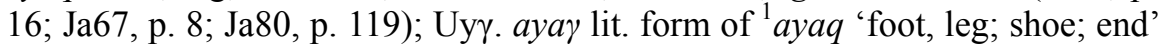
$\rightarrow$ *ayaqla- $\rightarrow$ ayaqlaš- 'to end, finish, be over, conclude, wind up, close' (Sch92, p. 35) vs. adaq 'end' < Mo. < Tu. (Rybatzki, forthcoming 2017); Lop.

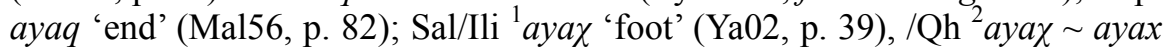

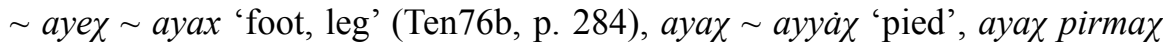
'doigt de pied' (Kak62, p. 176); YogW azaq 'foot, leg' $\rightarrow$ azaqtï̀ 'footed, having legs' (Mal57, p. 12), azaq azaq ' 'id.' (Ten76a, p. 174), azaq $a z a q^{h}$ $\sim a z a k$ 'id.', $k^{h} a z a q\left(\leftarrow k^{h} a \eta\right.$ 'kang' $\left.+a z a q\right)$ 'the foot end of the kang' (Ro00,

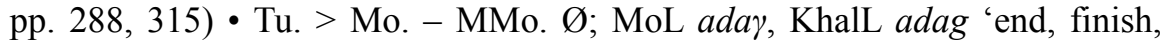
extremity; estuary, lower part or mouth of a river; last; extreme, farthest (as a frontier, limit, or region); the worst, of the lowest quality' (Le60, p. 9); Ord. adaq 'fin, extrémité, dernier' (Mos41, p. 3); Oir/D aday 'rive, fin, extrémité', OirL adaq (Ka58, p. 125); Kalm. $a d^{z} \gamma$ 'der od. das Letzte; Ende; Mündung des Flusses' (Ra35, p. 1) • Mo. > Tu. (Rybatzki id.).

(35, xxx) Özb. chader [Haz. kherga] 'tent' < Ir. - Özb/Afgh. čadar [Pe.] 'tent' (Ja38, p. 181; $\rightarrow$ ); Mgh/Bdx. làta 'Schleier', xayma 'Zelt' [Pe. čādor] (HeHiThe79, p. $214_{441}$ ) - Badghisi 1960, p. 186; Bailey 1979, p. 34; Eren 1999, pp. 75-76 (with further literature); Me55, p. 29; Morgenstierne 1936, p. 660 [MIr. > Khow. > Kal., Yd.]; 1957, pp. 451-452 (umbrella of mushrooms); M38, p. 57*; Rybatzki, forthcoming 2017; TMEN §1042; T No 4972; Vasmer iii, p. 379; VEWT p. $101 \mid$ Khot. kșatra $\sim$ kșattra, Skt. chattra- 'sunshade, rule; umbrella' (Konow 1949, p. 100; Bailey 1946, pp. 771-[775]); Pahl. čädur [c'twl] 'sheet, veil' (MacKenzie 1971, p. 21); Pe. čădar 'tent, pavilion; a mantle, scarf; a veil; a sheet; a shroud, winding-sheet; a table-cloth' (St pp. 383384); Taj. čådar čådir 'chador, yashmak; cover, veil, canopy; tent, pavilion, marquee; (lit.) puppet show/theater; etc.' (Mir06, p. 723; $\rightarrow$ ); Dari čâdar 'kleiner Schleier, Umhang; Zelt' (KiMi78, pp. 270-271) čáa $e^{e} r$ 'Schutzdach (gegen Sonne und Regen), Vordach; offener Schuppen; Überdachung; Überzelt' (KiMi78, p. 277); Wx. čòdīr 'sheet' (Pa75, p. 191), < Özb. or Taj.; Yd.

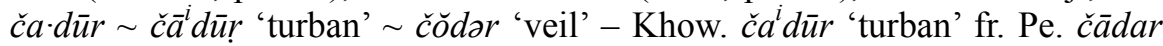
'veil' (M38, p. 201) vs. Yd. čâtir (čatîr) 'tent' - Khow. ča'tìr r in its turn is fr. MIr. *čātêr, cf. Pe. čădar $\sim \check{c} \bar{a} d i r$, Ru. l.-w. šater (M38, p. 204, Morgenstierne

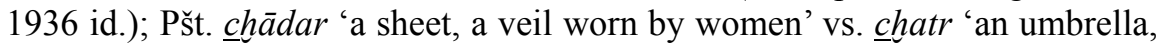
a canopy, a shade' (Rav.67, pp. 351, 356), čàdár 'covering, veil; sheet; chador' vs. '̌́at[a]r 'umbrella, parasol; canopy' (As85, pp. 307, 312); Urd. ćatrī [Pe.] 'umbrella, parasol; veil, canopy; tent, pavillion' ćatr (coll. ćatar) [Pe.] 'um- 
brella, parasol' (Pl pp. 423, 424) • Ir. > Tu. - Tu. (XI) čatïr 1.-w. ultimately derived fr. skt. chattra 'a (royal) umbrella'; this meaning, for which čowač is an alternative, has survived sporadically but the usual meaning is 'a (canvas) tent'. S.i.a.m.l.g. with some phonetic changes $(\check{c}-\sim \check{s}-,-t-\sim-d-)$, in some perhaps direct borrowings fr. Pe. or Ru. (C72, p. 403) - Tr. çadır 'tent' (Red p. 131); Khlj. čă:dur 'id.' (DoTe80, p. 96); Trkm. čadïr 'tent; marquee [шатер]' (BaKaXa68, p. 716); Kzx. šatïr 'tent, roof' (Shn66, p. 230); Kir. 'čatïr 'tent; roof, canopy; screen' (Ju p. 352); Özb/Buch. [Pe.] čåudir 'a tent, a pall' (O05, p. 14), Özb. čådir [Pe.] 'tent; bed curtain; chador; screen, curtain' (CAHG p. 60; Bor59, p. 526), Özb. > Taj. čådir, Özb. or Taj. > Ar/Buch. čōdir 'Zelt' (Do69, p. 303); Trki čader $\sim \check{c} a: d e r \sim \check{c} \varepsilon d \varepsilon r \sim \check{c} \varepsilon d e r \sim \check{c} \varepsilon d i r$ [Pe.] 'tent' $\rightarrow$ čaderga: $h \sim$ čederga: $h$ [Pe.] 'camp' (Ja64, p. 63; Me55 id.); Uyy. čedir 'tent' (Sch92, p. 357); Lop. čadir '(wedding) tent' (Mal56, p. 187); Sal/Ili ča:dər 'shed, tent' (Ya02, p. 66), /Qh čadir 'tente' (Kak62, p. 177) • Tu. > Mo. (TMEN id.) - MMoM, A cacir [Cag. MTu. čadï $\sim$ Cag. čadur] $\sim \mathrm{P} *$ cacar 'tent' $\rightarrow \mathrm{P}$ cacartan- $a[$ cacar $-+-t A n-+-A]$ 'to those having a tent' (Rybatzki, forthcoming $b$ ); MoL, KhalL cacar 'large tent, open tent, awning tent, hut, stall' (Le60, p. 156); Kalm. čačr $\sim$ čäčr 'offenes Zelt, Zelt aus Leinwand, Zeltdach; /Dörböt (auch:) leichte, weisse Wolken, die über das Feld ihre Schatten werfen' (Ra35, pp. 437-438) - Tu. > Tib. (TMEN id.), according to Laufer (1916, p. 483) Pe. > Tib. • Mo. > Tung. (Rozycki 1994, p. 42; TMEN id.) - Jur. čačari 'tent' (Kane 1989, p. 258 ${ }_{620}$ ); Ma. cacari 'Sommerzelt' (Hauer p. 71).

$(16, \mathrm{xv})$ Özb. khatun [Haz. kaini] 'woman' (17, xviA) khatun [Haz. beri] 'lady'। Cf. Moyolī vocabulary

(22, xixB) Özb. kablan [Haz. kablu] 'leopard' | Cf. Hazarāgī vocabulary

(11) Özb. kahs [read: kash] [Haz. kash] 'eyebrow' | Cf. Hazarāgī vocabulary

(12) Özb. kaisagh [Haz. kabagh] 'eyelid' - Badghisi 1960, pp. 46, 100; M38, p. 21* (both sources have no forms resembling the Özb. word as given by Mackenzie) - Unclear; could this be a writing mistake for kabagh, i.e. -is- instead of -b-? For kabagh cf. Hazarāgī vocabulary

(24) Özb. ketkhoda (xx) katkhodr [Haz. mir] 'chief' < Ir. - Bailey 1979, p. 50; Me55, p. 66; M38, p. 30*; Ry06, pp. 547-548 - Pahl. kdg-hwt'y [kadagxwadāy] 'householder, master of the house; 〈house-lord, title of petty kings reigning before the Sassanian period' (MacKenzie 1971, p. 48; Nyberg 1974, p. 116); MPeM, PrthM qdyxwd'y [kadexwadāy] 'master of the house' (Boyce 1977, p. 52; Durkin-Meisterernst 2004, p. 204); Pe. kadkhudā 'master of the family; a bridegroom, married man; anyone looked up to with reverence and respect; a magistrate; a king; an elderman, a sheriff' (St p. 1018); Taj. kadxudå '(lit.) verheirateter Mann; Hausherr; (hist.) wohlhabender Hauswirt; (hist.) Dorfältester' (Mir06, p. 268); Darī kadxodā 'Hausherr; Ältester der Generation; verheirateter Mann; Jungverheiratete; Bräutigam' (KiMi78, p. 580); Sgl. katxudāi 'houseowner', Š $\gamma$. katxudâ' $\bar{\imath}[\mathrm{Pe}$.] 'the position of a houseowner, marriage', Srq. kat-xudái 'marriage' (M28, p. 58; M38, p. 36*); Pšt. kadxudā 'head man of a village or family; married man, master; marriage, the office of 
kadxudā' (Rav67, p. 783); Urd. kat-khudā 'master of the house, head of the family or household; a married man; a bridegroom; a viceroy or locum tenens' (P1 p. 812) • Ir. > Tu. - Tr. kethüda '(hist.) chief steward, majordomo' (Red p. 421); Khlj. kätxudå [< Pe.] 'Hausherr' (DoTe80, p. 149); Trkm. ketxuda [ketxuda:] '(hist.) Ältester, Senior; aqsaqal' (BaKaXa68, p. 396), Trkm/Khiva ketkhüda 'chef de clan chez les Turkmènes, de même rang que les atalik, beglerbegi, soumis également au hakim' (Baskakov 1992, p. 295); Trki kedzuda:

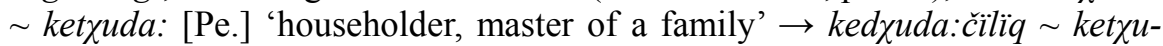
da:čiliz [Pe. Tu.] 'the quality or functions of a householder, housekeeping', $\rightarrow$

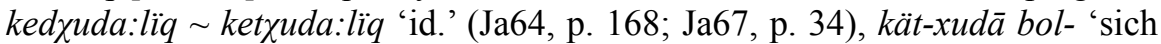
verheiraten, einen eigenen Hausstand gründen' (Me55, p. 66) • Ir. [Kurd. kayxu' $a$ 'Schöffe, Schulze' kekhüa [= kexüa] 'headman'] > MMoU *kaiquva $\rightarrow$ (pl.) kaiquvas 'Schulze' (Doerfer 1974, pp. 99-110; Ry06 id.) • Found in some Ir. and Tu. languages surrounding Özb., but not in Özb. itself.

(lvii) Özb. qil [read: qiz?] (53) qiz [read: qil?] [Haz. (53) kach (lvii) katch] 'bent, crooked' - Haz. kil 'curve, curved'; Pe. (Du73, p. 66) - Badghisi 1960, p. 191; M38, pp. 8*, 16* • (??) Pe. kh $h u l$ 'bent, curved, crooked; mad; ashes; the fundament' (St p. 469), kāl 'bent, crooked; etc.' (id. p. 1008) - Unclear, cf. ( $\downarrow$ ) qiz.

(6) Özb. kishkina [Haz. chuknai] 'small, little' - Özb/Afgh. kičik 'small, little',

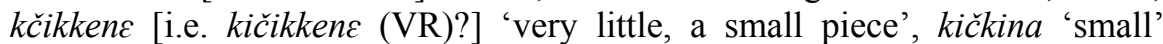
(Ja38, p. 205; $\rightarrow$ ); Mgh/K kičiks 'klein', /N kečck'ıt 'die Kleinen, Kinder' < Tu. kičik + Mo. pl. -t (W72a, p. 170), cf. also Mgh/ $\mathrm{L}_{2}{ }^{\circ}$ katkan 'ganz klein, winzig; Winzling' (doppeltes Deminutivsuffix), inakat kan 'dieser Winzling' (W77, p. 152) - cf. ( $\downarrow$ ) kuchi; M38, p. 52*; Sevortjan v, pp. 75-77; TMEN $\S \S 1694-1695$; VEWT p. 269 • Tu. (VIII) kičig 'small', with some extended meanings like 'puppy' [this is a different word (VR)]; s.i.a.m.l.g., with some phonetic changes (C72, p. 696) +-KInA $(\sim-K I y A)$ den. n. s. (diminutive) $\rightarrow$ Uig. kičigkiyä 'minute, little' (Erdal 1991, pp. 47-56) - Trkm. kiči 'small, little; young, junior; less; youngest' (BaKaXa68, p. 401); Kzx. kušl 'younger, smaller, less', kǔskene 'small, little; a little', kiškentay 'little, small' (Shn66, pp. 128-129); Kir. kičik kičü 'small, little; (kičik also:) modest', kičinekej 'tiny' (Ju p. 390); Özb/Buch. kičik 'small, young', kičkantaj 'very small' [< Kzx. $\rightarrow$ ], kiškina 'small (thing)' (O05, p. 32),/Urg. kičči 'small, little' (Dob74, p. 93), Özb. kičik (lit., Pe.) 'small, litte; young; minor', kičkina 'small, little, tiny', kičkintåy 'junior, tot, small fry' (CAHG p. 145; Bor59, pp. 214-215), the last word Özb. < Kzx. ( $\leftarrow$ ), Özb. > Taj. kičkina 'klein' (Do67, p. 23); Trki $k i c ̌ i k \sim k^{i} c^{i} i k \sim k^{i} c^{\prime} i k$ 'small, little, young, youngest', $k$. $k$. 'very small', $\rightarrow$ k.ken $\varepsilon$ 'a little, a small quality, somewhat small', $\rightarrow$ kičiklik 'being small' (Ja64, p. 172; Ja67, p. 34; Ja80, p. 132), $\rightarrow$ kičikkine ( $\leftarrow$ kičik + kine) 'a small quantity' (Ja96, p. 41); Uy $\gamma$. kičik 'small', $k$. bala 'small child', $\rightarrow$ kičikkinä 'very little (endearing voice of kičik), $\rightarrow$ kičiklä- 'to become small' $\rightarrow$ kičiklät- 'to narrow, reduce', $\rightarrow$ kičiklik 'childhood, youth' (Sch92, pp. 725-726); Lop. kičik 'small, little', kič(i) kenä 'tiny' (Mal56, p. 136); Sal/Ili kiča 'young, small' kiči 'little' (Ya02,

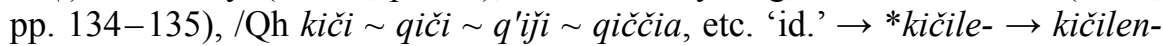


'diminuer' (Kak62, p. 183), kiči kici kizi kiz 'i 'small, little, young' (Ten76b,

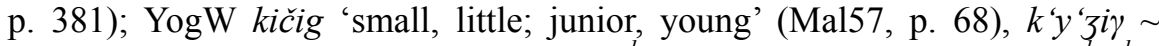
$k^{\prime} y c y y \sim k^{\prime} y z^{\prime} i g$ 'id.' (Ten76a, p. 190), $k^{\text {h }}$ ciq 'small; young of age' $\sim k^{h} i c^{h} i \gamma$ etc., now mostly replaced by miča, $k i^{\text {h' }}$ ciq qol 'fore arm' (Ro00, pp. 309, 346) • Tu. > Mo. $(\leftarrow)-$ Oir/D kičig 'chiot', OirL kičiq (Ka58, p. 147); Kalm. kič̣̣g 'Junges (des Hundes)' $\rightarrow$ kičı̆glza 'Junge werfen (Hunde, Wölfe etc.)' (Kempf

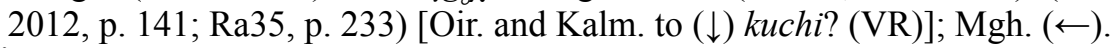

(53) Özb. qiz (lvii) qil [Haz. (53) kach (lvii) katch] 'bent, crooked' • (??) Pe. qūz 'curved, crooked' (St p. 994), kūz 'hump, crooked back; sky' (id. p. 1061); Pšt. $k \bar{o} z$, Pšt/Waz. kēż $\sim k \bar{o} z \dot{z}$ 'curved'; no clear etymology (M27, p. 35); Yd., Mj. $k u \check{u} \check{z}$ ' 'crooked' - cf. Sgl., Pe. küž etc. (M38, p. 221) • Unclear, the form qiz might be a mistake for $(\uparrow)$ qil.

(29, xxv) Özb. kok [Haz. eshel] 'blue' - Özb/Afgh. kok 'sky; green, blue' (Ja38, p. 206; $\rightarrow$ ); Af̌s/Kbl gēk 'id.' (Li57, p. 124), /Q gūk 'Himmel', /FX gǖk 'grün', /Kbl gēk gek 'blau' gük 'Himmel' (DoHe89, pp. 26, 39); Mgh/Mrv kükd 'blau, gün' (Ra05, p. 31), /Me koka 'green, blue' /N koká 'grün' /B kokó 'blau' (W71, p. 170 54), /Le kokà 'green' /Mr, M, MS kokka 'bleu, vert' (Li54, p. 136), /N kək'九 'grün' /B kok's 'blau' (W72a, p. 170), /Bdx. ko k [Tu. (VR)] [Pe. äbi, kabüd] 'hellblau, (himmel)blau' (HeHiThe79, p. 218551,552), /Kd kokë bol- [Pe. šiküfa kardan] 'erblühen, ergrünen' (DoHe93, p. 58), Mgh/L $\mathrm{L}_{1} k \bar{u} k$ 'Himmel' [form and semantics are Tu. (VR)], kükahčč 'grünend' (W75a, p. 143) /L L kükuh [Mo.] 'grün' (W77, p. 154) - Khabtagaeva 2001, pp. 159160 (Index); Laude-Cirtautas 1961, pp. 77-85; Li65, p. 293; Li66, pp. 174175; Mayrhofer 1960, p. 275; MYYC p. 378; M38, p. 9*; Nu11, pp. 424-425; Róna-Tas-Berta 2011, pp. 519-521; Ry06, pp. 543-545; Rybatzki 1994, pp. 238-239, forthcoming 2017; Sevortjan iv, pp. 66-68; TMEN §1677; VEWT p. 287 - Tu. (VIII) kök basically 'the sky'; hence 'sky-coloured, blue, bluegrey', etc.; for a similar range of colours cf. yašil. S.i.a.m.l.g. in both meanings except NE, where only the second (various sec. forms of täyri reborrowed fr. Mo. being used in the first) (C72, pp. 708-709) - Tr. ' gök 'sky, the heavens, the firmament; celestial, heavenly', '2gök 'blue, sky-blue, azure, aquamarine; (prov.) unripe, green (fruit)' (Red p. 269); Khlj. $k l^{e} k \sim k i^{e} k \sim k \ddot{u}^{\ddot{o}} k$ 'grün'; in der

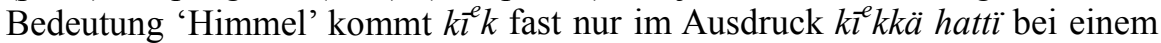
Spiel vor, vgl. aber hadaqï yerdä $u k \imath^{e} k d \ddot{a}$ hizilmiš 'sein Fuß ist «von Erde und Himmel〉, d.h. 〈von Erde und Land' getrennt' (DoTe80, p. 151); Trkm. gök 'blue, azure; sky blue; green; unripe, immature, green; sky, heaven; green vegetables [Ru. зелень]' (ВаKaXa68, pp. 198-199); Kzx. kök 'sky, heaven; blue (of sky, eyes, paper, etc.); green (of grass, leaves, hay); gray (colour of cattle and horses); grass, herb; vegetables; bluing', $k$. ala 'apple-gray (colour of horses)' (Shn66, p. 133); Kir. kök 'sky, heaven; blue; green, immature, green grass; (hist.) colour of mourning; gray' (Ju pp. 417-418); Özb/Buch. kök kåk ‘blue, green' (O05, p. 34), /Qil kök ‘blue', k. at 'roan' (Ja37, p. 50), Özb. kok 'blue, azure, blue-grey; (animals) grey; the sky, the heavens; green plants, grass, verdure; greens, herbs', $k$. àt 'a grey horse' (CAHG p. 148; Bor59, 
p. 228); Özb. > Taj. kok (Do67, p. 24); Chor. gö̈ $k \sim$ gök $\sim$ göy $\sim$ gek $\sim$ gey 'blau' (DoHe89, p. 39); Trki kök (i) 'sky, heaven', (ii) 'blue, green, roan (of horses and donkeys), bay (of sheep), (green> i.e. young', $k$. čibin 'horse-fly, bat-fly', k. pit 'dog-louse', $k$. taš 'blue vitriol' (Ja64, p. 176; Ja67, p. 35; Ja80, p. 133: Ja96, p. 41), k. beši 'der Aufseher über das Grün-Wasser' vs. kök 'schön' $\leftarrow$ körk (Me55, p. 69), cf. also geǰigä süyi 'water of convolution' (phase during irrigation), called also kök süji 'green-water' < Mo. gejige 'tail, plait, braid' (Me55, pp. 43-44; Rybatzki, forthcoming 2017); Uy fresh bruise' $\sim{ }^{3} k o ̈ k$ 'green grass; young crops; vegetable; lucerne, alfalfa; tassel, leaf', (hist.) kök beši 'water manager, one of the begs who was in charge of equitable distribution of irrigation water', also kökweši, $\rightarrow$ kökata 'paternal great-grandfather', kökana 'paternal great-grandmother' (Sch92, pp. 705-706; on pp. 706-708 a large amount of botanical and zoological terms having kök as their first element); Trki/Ili kok 'blue, bluish green' (Ha91, p. 44); Lop. kök 'green', kök ala darya 'river' (Mal56, p. 136); Sal/Ili gö ${ }^{h} x$ 'green, vegetable' vs. ' gök 'sky', 'gök 'vegetable' $\rightarrow$ göger- 'to turn green or blue' (Ya02, pp.

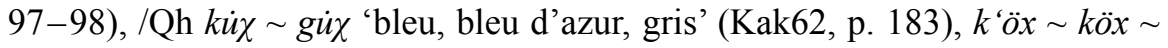
$k^{\prime} o ̈ n \sim k^{\prime} u$ 'blue' (Ten76b, p. 401); YogW kök 'blue', kök ot 'green grass' (Ma157, p. 68), kök $\sim k u k \sim k \ddot{u} k \sim k \ddot{u} k^{\prime} \sim k^{\prime} u ̈ k \sim k^{\prime} \ddot{u}$ 'k $\sim k^{\prime} \ddot{u}{ }^{\prime} k^{\prime}$ 'blue' (Ten76a, p. 187), kük $\sim$ kök 'blue' $\sim k \ddot{u} k^{h} \sim k^{h} \ddot{u}^{h} k^{h} \sim k^{h} \ddot{o} k^{h} \sim$ kek $\sim$ yek 'id.; green, gray (of a horse)' $\sim$ kï:k 'blue' $\sim$ kök 'grey', qara kük $\sim$ qara kük ${ }^{h}$ 'dark blue, indigo' (Ro00, pp. 313-314) • Tu. > Mo. - MMoA kök [MTu. kün 'sun'] 'sky, heavens' vs. MMoM/S kökö 'blue, (S also) green' U/A köke 'blue, (A also) sky, heaven (last semantics < Tu.), M kökö bicik 'blue script (on white paper)', S kükü burca [q] 'green peas or lentils', S kökö cilawun 'espèce d'épingle pour les cheveux faite de jade de couleur verte' $\approx \mathrm{M}$ kökö gürü, S kökö ebesü 'green grass, lawn' [MoL köke ebesün 'green grass'], A köke lāhĭ̌ša 'a kind of vermicelli', S kökö teri.ün 'taon' [MoL köke türüü köke türü] (Rybatzki, forthcoming b); EMoL köke 'blue', köke terigütü 'blue-headed or blue-bottle fly' (Ka09, p. 156) MoL köke, KhalL xöx 'blue, sky-blue; green; ash-coloured, dark (of face)' (Le60, p. 482); Ord. gö $\chi \ddot{o}$ 'bleu, vert (végétaux); gris (chevaux, chèvres etc.); de couleur cendrée (bœufs); noirâtre; qui n'a pas encore perdu son humidité naturelle (végétaux); frais, cru, qui n'a reçu aucune préparation (peaux d'animaux tués)' (Mos41, pp. 268-269); Oir/D kóko, /Dz kökkö $\sim k \ddot{o} k$ $\sim k \dot{k} k$ 'bleu', /D kók türgün 'mouche à viande' (Ka58, p. 148); Kalm. ${ }^{1} k \ddot{o} k^{o}$ 'blau; blaugrün; grün, aschgrau; etc.' (Ra35, p. 236); Mgh. $(\leftarrow) \bullet$ (Recent) Mo. $>$ Tung. (MT §291; Rozycki 1994, p. 145; TMEN id.) - Ma. kuku (i) 'grün, blau, grün', (ii) 'die Amba Hiyan genannten Weihrauchsorte', kuku fulan 'blaugraues Pferd', kuku ihan 'graues Rind', kuku ulhûma 'blaugrauer Fasan' (Hauer p. 315).

(13, xii) Özb. koz [Haz. oqba okra] 'eye' - Özb/Afgh. koz $\sim$ ko:z 'id.', $k$. qapayi 'eyelid' (Ja38, p. 207; $\rightarrow$ ); Af̌̃/Q güz $\sim$ /S güs /Kbl gez /A göz 'id.' (DoHe89, pp. 26-27); Mgh/Bdx. koz [Pe. čašm] 'id.' (HeHiThe79, p. 198 29 ) Me55, p. 70 (in erweiterter Bedeutung 'Gesicht', fehlt in den Lexicis in dieser 
Bedeutung); M38, p. 21*; Sevortjan iv, pp. 60-63; TMEN §§1015, 2109, 2110; VEWT p. 295 • Tu. (VIII) ${ }^{1} k \ddot{z} z$ 'eye', c.i.a.p.a.l.; göz in NW Kum.; SW Osm., Trkm.; with extended meanings like 'a small aperture', e.g. 'the eye of a needle', and used in many idiomatic expressions. There is obviously a very old etymological connection with kör- (C72, p. 756) - Tr. göz 'eye; sight, vision; etc.' (Red pp. 275-278); Khlj. kez köz 'Auge' (DoTe80, pp. 149-150); Trkm. göz 'eye/s' (BaKaXa68, pp. 195-197); Kzx. köz 'eye; eye (of a needle, etc.), eyelet, opening; spring, source; (fig.) supervision, care' $\rightarrow$ közšz 'eyeless' (Shn66, pp. 132-133); Kir. köz 'eye' (Ju pp. 414-416); Özb/Buch. kyös $\sim$ kus 'id.', kyös yaši 'tears', kyözin karazi 'pupil of the eye' (O05, p. 33), /Qil. köz 'eye' (Ja37, p. 50), /Urg. göz 'eye', gözzi 'his eye' (Dob74, p. 90), Özb. $k o z$ 'eye; glance, sight; hole, opening' (CAHG p. 151; Bor59, pp. 226-228), *ala koz > Ar/Buch. alakúz 'grauäugig' (Do69, p. 301); Trki köz kö·z küz 'eye, eye of pipe (decoration)' $\rightarrow$ közsüz 'blind', $\rightarrow$ közlük 'seeing', $k$. yaš 'tears', k. qapaqï 'eyelid' (Ja64, p. 178; Ja67, pp. 35-36; Ja80, p. 133); Uy köz 'eye; opening; inlaid jewelry worn on a ring or other ornaments; (bot.) bud; the best of a kind; knack' (Sch92, pp. 703-705); Trki/Ili koz 'eye' (Ha91, p. 44); Lop. köz 'id.', közlük 'with eyes', širin közlük 'with nice eyes' (Mal56,

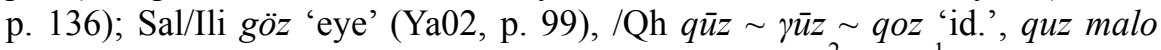
'globe de l'œil', quz qarasa 'pupille' (Kak62, p. 189), ${ }^{2} k \ddot{o z} \sim{ }^{1} k o z \sim k \bar{u}$ 'id.' (Ten76b, p. 394); YogW köz küz 'id.' (Mal57, pp. 68, 70; Ten76a, p. 187), köz $\sim$ göz küz kioz 'eye; source, well, spring; opening, hole' (Ro00, p. 311).

(33, xxix) Özb. kuchi [Haz. kuta] 'dog' · Mgh/Bdx. kučük ( kopāk) [Pe. sag] 'id.', rï̌il [Pe. čūče-sag] 'Welpe' (HeHiThe79, p. 20099, 100), máyda [Pe. kūcek] 'klein' (id., p. 215 ${ }_{482}$ ) - cf. ( $\uparrow$ kishkina; Golden 1991, p. 51; Me55, p. 71; M38, p. 45*; Ry06, p. 536; TMEN §§1620, 1664; Tryjarski 1979, p. 308; (??) VEWT pp. 286, 294 - As stated by Clauson (C72, p. 696), the Tu. forms with rounded vowels are probably not to be connected with $(\uparrow)$ Tu. kičig, but are somehow related to Pe. $k \bar{u} c ̌ a k(\rightarrow) \bullet$ Pe. $k \bar{u} c ̌ a k$ 'small, little; a musical mode or style; diminutive; younger, junior; a youngster, a child' (St p. 1059); Taj. kučuk 'dog', kūčak 'small, little' (Mir06, pp. 294, 298; $\rightarrow$ ); Par. kučuk ku'čōk 'dog'; cf. Badakhshi kūcük 'puppy', Orm. ku'čuk 'puppy, cub' (M29, pp. 263264, 398); Wx. kūček 'puppy' - Pe. (M38, p. 525); Urd. kūćak (coll. koćak) [Pe.] 'small, little, diminutive; younger, junior (syn. ćhoțā)' (Pl 860) • Pe. > Tu. - Tr. küçük 'little, small; young, little; petty, small, small-minded; petty, minor, low-ranking; miniature, small-scale; petite, dainty' (Red p. 461); Khlj. kuči 'Hund (Kinderwort)'; vgl. Tr. kuçu, ChorTu. kuči, Ir. dial. kuču 'Hund' (DoTe80, p. 156); Trkm. güjük [гүжүк] 'puppy, whelp' $\rightarrow$ güjükle- 'to whelp' (BaKaXa68, p. 217); Kzx. küš̌k 'puppy; young animal' $\rightarrow$ küš̌kte- 'to whelp, cub, pup' (Shn66, p. 132); Kir. küčük 'puppy, wolfling, tiger cub' $\rightarrow$ küčüktö'to whelp, pup, cub' (Ju p. 474); Özb. kučuk [Pe.] 'puppy; (coll.) dog' (CAHG p. 156; Bor59, p. 226), Özb. > Taj. kučuk kücük 'Hund' (Do67, p. 24); Otü. küčük 'Junges von Hund oder Wolf' (Me55, p. 71), kučik küčük 'Ferkel, junger Hund' (LC11, p. 96), Trki kücùk ‘puppy, whelp' (Ja64, p. 179), kučuk ‘Hünd- 
chen' (Ja67, p. 36) $\rightarrow$ kücükle- 'to whelp, to farrow' (Ja64, p. 179; Ja67, p. 36;

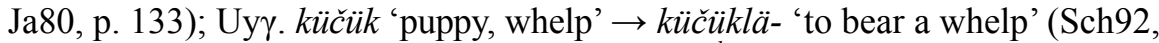
p. 715); YogW kitik (kïtikki) 'puppy, cub' kitith $\sim$ qïtiq $\sim$ qïdiq $\sim$ ketik $\sim$ kitiik (Ro00, p. 310) - Tu. > Mo. (Rybatzki, forthcoming 2017) - MMoS gücük 'Welpe, junger Hund', A cinayin kücük [Cag. böri balasi] 'young of the wolf' (Rybatzki, forthcoming $b$ ).

(40, xxxv) Özb. lambur [Haz. (40) taqim (xxxv) takim] 'calf (of the leg)' - M38, p. 12*; Sköld 1936, pp. 142-143/Nr. 125, $129^{\mathrm{a}-\mathrm{b}}$ (also of a goat) • Pe. lambar lumbur 'strong, fat; buttocks' (St p. 1129) - The semantics given by Mackenzie do not seem to be exact, prob. 'buttock, buttocks; backpart of the leg from the knee upwards' is meant here. See the corresponding Haz. term taqim takim < Mo. - MoL takim, KhalL taxim 'the ham, the hollow behind the knee joint' (Le60, p. 770); Kalm/Ölöt takm 'die Kniebiegung, die innere Seite des Knies, der untere Teil des Oberschenkels hinten' (Ra35, p. 375).

(8) Özb. maraka [Haz. maraka] 'meeting, assemby'| Cf. Hazarāgī vocabulary

(2) Özb. oti [Haz. darbaqad dabacad (hastan)] 'past, behind' - Özb/Afgh. ot- 'to pass, to move, to come over, to live' (Ja38, p. 214; $\rightarrow$ ) - M38, p. 8*; Sevortjan i, pp. 554-555; VEWT p. $376 \cdot$ Tu. VIIIff ${ }^{1}$ ot- the basic connotation is movement through or over; it is both trans. and intrans., in the latter case almost always with 'time' of some sort as the subject. S.i.a.m.l.g.; in SW only Trkm, and XX Anat. (C72, p. 39) - (??) Tr. öte 'the further side of, the other side of; other, yonder, far (side); the rest of; the other side' (Red pp. 550-551); Trkm. öt- 'to pass, pass over; pass by; to move, pass on; to cross, cross over; to pass, elapse; to expire (of time)' (BaKaXa68, pp. 507-508); Kzx. öt- 'to pass, to pass by, to go by; to elapse (time), to be over; to flow, to run (of water); to pass over, to pass through, to cross; to be converted, to turn into; to escape; to die; etc.' (Shn66, pp. 294-295); Kir. öt- 'id.' (Ju p. 102); Özb/Buch. ut- 'to pass; to forgive, exculpate, excuse' (O05, p. 58), /Qil. öt- 'to pass' (Ja38, p. 51), /Urg. öt- 'to pass', ikki ̈̈̈̌ gün ötmīn 'after a few days have passed (Dob74, p. 94), Özb. ot- 'to pass (by, through, over, from, to), to go through; to pass by, to go by, to be over (time); to move (to, on), to go, to transfer; to travel; to cut through (knife); to cross; to surpass, to exceed; to be felt, to affect, to influence, to hurt', otmiš 'the past' (CAHG pp. 198, 199; Bor59, pp. 591-592, 589); Trki $\ddot{t} t-\sim \dot{u} t-$ 'to cross, to pass, to pass by, to pass through, to ford, to forgive, to pardon, to reach' $\rightarrow$ ötil- 'to be passed on, to be known', $\rightarrow$ ötgän

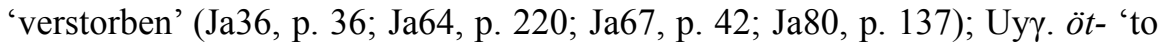
pass, cross, pass through, traverse, ford; etc.' $\rightarrow$ ottkän 'past, previous', $\ddot{o} . z a-$ man '(gr.) past tense', $\ddot{o}$. yil 'previous year', $\rightarrow$ ötmüš 'the past' (Sch92, pp. 442-443); Trki/lli $\dot{o t-}$ 'to pass, go through; (aspectual verb:) successfully executed action' (Ha91, p. 47); Lop. öt- 'to pass by [проходить мимо], to pass (by), go [проезжать], to pass, be over, etc. [миновать]' (Mal56, p. 153); $\mathrm{Sal} / \mathrm{Ili}$ öt- $\sim \ddot{o}^{h} t$ - 'to pass, cross' (Ya02, p. 148), /Qh $\dot{o t}$ - 'passer' (Kak62, p. 185), öt- $\sim \bar{o} t-\sim o t e-\sim \ddot{o}$ '- $\sim \dot{u} t-\sim \overline{\dot{u}} t-$ 'to pass, pass over/on, elapse; cross; etc. [проходить, переходить]' (Ten76b, p. 433). 
Özb. (36, xxxi) oz [Haz. choku] 'cheekbone,2 - Mgh/Mrv yōsun 'Knochen', Mgh/L 1 $y \bar{a} s \bar{u} / n$ 'id.', (pl.) /N jos'ud (Ra05, p. 30; W72a, p. 168; W75a, p. 171) • Badghisi 1960, p. 42; Li62, p. 73; TMEN §405 - MMoM/S/A yasu/n [MTu. Cag. sü̈ük (?süyök) Cag. süyük Cag. süyek] U yasun 'bone', (pl.) A yasunlar (Mo. Tu.) [Cag. süyüklär] (Rybatzki, forthcoming b); EMoL yasun 'bone' (Ka09, p. 329); MoL yasu/n, KhalL yas/an '(i) bone, skeleton; dead body, corpse, remains; dice; frame; (ii) race, family, clan; descent; (iii) kernel, stone of a fruit, pit; (iv) quality (usually of paper or textile)' (Le60, p. 430); Ord. yasu 'os; cadavre; dé à jouer; clan; ossature, charpente, carcasse, qualité, substance d'un objet' (Mos41, pp. 398-399); OirD/Dz/U yas yasn 'os; clan, nationalité, OirL yasun (Ka58, p. 146); Kalm. yasn 'Knochen, Geschlecht' (Ra35, p. 217) - Mo. > Tu. (TMEN id., VEWT 194) - Cag. yasun [Osm. ustuxan, kemik] 'Knochen' (Kúnos 1902, p. 102).

(48, lii) Özb. solan (read: sholan) [Haz. qima] 'stew' < (Tu.) $<$ Mo. $-\left(\right.$ ?) $\mathrm{Mgh} / \mathrm{L}_{1}$ šllān 'Decke, auf der das Essen serviert wird' (W75a, p. 159) - Badghisi 1960, p. 165 ['soft rice dish']; Buell 1990; 1999, pp. 213, 216-218; Buell-Anderson 2010, pp. 654 (soup), 655 (šülen); Eren 1999, p. 390; EWAi ii, p. 632 [Skt. śāli- 'Reis']; MYYC p. 723; M38, pp. 46-47*; Ry06, pp. 692-693; T N ${ }^{\circ}$ 12415; TMEN §246; VEWT pp. 446-447 [Cag. šilän 'öffentliche Festlichkeit', šölän 'für das gemeine Volk bereitete Suppe'; Otü. $(\rightarrow)<$ Mo.] $・$ Pe. šula 'a dish called šula pilaw' (St p. 758); Taj. šavla $\sim$ šūla 'rice porridge with meat and carrots [рисовая каша с мясом и морковью]; gruel [размазня] (Mir06, pp. 752, 772); Yd. šulo 'rice and meat boiled together' - cf. Pe. šila (Ł *šălya?) (M38, pp. 251-252); Wx. šūla 'rice porridge with meat [каша рисовая с мясом]' (Pa75, p. 264); Pšt. shola' $h$ 'rice and pulse boiled together and given to the sick' (Rav67, p. 664), ${ }^{4}$ šola 'liquid rice porridge [жидкая рисовая каша], rice gruel [рисовая кашица]' (As85, p. 537); Urd. šola 'a dish of rice and pulse boiled together till quite soft' (Pl p. 737) $[<\mathrm{Ir} . / \mathrm{Tu} .]^{3} \cdot \operatorname{Tr}$. (?) şölen 'banquet, feast; big party; superb display of artistic skills' (Red p. 661); Trkm. š̈̈le [шүле] 'шуле' (ВаKaXa68, p. 764); Kzx. söl 'meat juice' (Shn66, p. 187); Özb. šulån 'hot food given to the poor (CAHG), gratuitous dish/food [даровое кушанье, даровая пища] (Bor59)' (CAHG p. 285; Bor59, p. 548);

${ }^{2}$ For the explanation of this word I am in debt to Prof. Michael Weiers who wrote in an email (02.12.2013) as follows: "Für Mackenzies oz bietet sich ausgehend von den im Mogiolī ausgewiesenen Einzelwortbelegen $<y \bar{a} s \bar{u}>\left[j \jmath^{\prime} s u\right]$ und $<y \bar{a} s \bar{u} n>\left[j \jmath^{\prime} s \mho n\right]$ in lautphysiologischer

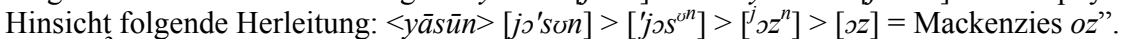

${ }^{3} \neq$ Pe. šă $\bar{l} \bar{l}$ 'rice in the husk', šăliyi $\bar{a} b \bar{l}$ 'a kind of wild rice' (St p. 724); Taj. šoli 'brown rice; rice' (Mir06, p. 768); Wx., Srq. shâl [Pe.] Wx. grünj [Tu.] 'rice in the husk (not grown in those valleys)' (Sh76, p. 107); Pšt. šōle 'rice in the husk', Pšt/Waz. šēlē, borr. fr. Ind., Skt. śāli-, Kati ša $\bar{a} \bar{l}$; Pšt. $\check{s} \bar{a} l a \bar{l}$ 'rice' is borr. from Pe., itself a l.-w. from Ind.; also Par. šêl $\leftarrow{ }^{*} s ̌ \bar{s} \bar{l} l$ - (M27, p. 73; M03, p. 78); Par. šel 'unhusked rice'; early 1.-w. from Ind., Wai. šeli-mai (M29, p. 290); Orm. šọl, Orm/Kan. šōl 'rice in the husk' - Pšt. (M29, p. 407); Pšt. shăala ' $\bar{\imath}$ 'rice before it is reaped or threshed' $\approx$ shola ' $h$ 'rice in the husk, paddy' (Rav67, pp. 639, 664), šóle $\sim$ šoli 'raw rice' (As85, p. 537); Urd. śáli [Hi. śálī 'rice; a kind of white rice (growing in deep water); red rice (requiring only a moist soil)' (Pl p. 718). 
Otü. šilän 'die für die Soldaten abgekochten Speiserationen' šöllä 'ein Gericht aus Fleisch und Fett' (VEWT id.), šốlä 'fettes Reisgericht mit einge-

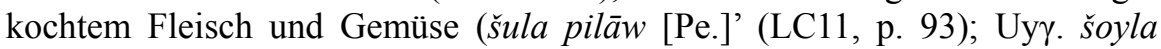
'a very thick porridge consisting mostly of rice, fat, carrots and meat' (Sch92, p. 523) • MMoM/S šülen A šilen U/A sülen [Ar. al-šūrbā 'potage, soup', Pe. šūrbā 'broth, soup, gruel', Cag. MTu. šorba] 'soup, bouillon' U sülegen 'broth' (Rybatzki, forthcoming b); MoL silü/n šülen, KhalL šöl 'soup, bouillon, broth' (Le60, pp. 708, 759); Ord. šölö 'bouillon de viande' (Mos41, p. 630); Oir/D šölün 'soupe', OirL šülün (Ka58, p. 159); Kalm. šüln (rarely /Ölöt šiln $)=/$ Dörbet šöln 'Bouillon, Suppe' (Ra35, p. 371); Mgh. $(\leftarrow) \bullet$ Mo. > Pe. > Š $\gamma$. šelun 'feast on the occasion of a wedding or a circumcision' (TMEN id.), Orš. šila ${ }^{u}$ ' 'feast', Wx. šeiliōn 'cooked food' (M74, p. 77) • Mo. [> Ir./Tu.] > Tu. («; Rybatzki, forthcoming 2017; TMEN id.; VEWT id.) • Mo. > Tung. (TMEN id.; Schmidt 1923, p. 32) - Ma. sile 'helle Fleischbrühe, Bouillon' (Hauer p. 414)

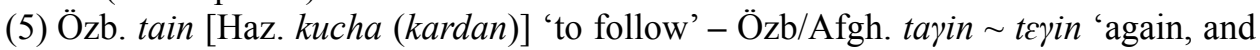
then, but then' (Ja38, p. 225; $\rightarrow$ ) - VEWT 457 • Tu. (VIIIff) taqï. It is most often used in the early period as a conjunction at the beginning of a sentence meaning 'and; furthermore', or after one or two words meaning 'also', but there

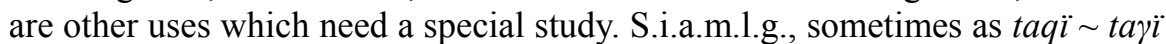
or daqï dayi (in NC Kir.; NW Kkp. both tayi and dayi occur), sometimes (NE Tuv., SC Özb., NW Kaz.) in the extended from tayin, sometimes as an enclitic $t a \sim t e \sim d a \sim d e$. In SW Az., Osm. enclitic $d a \sim d e$ is common; in Osm. two forms daxl 'and, also' and daha 'more' evolved; in Trkm. only dagï (C72, p. $466)-\operatorname{Tr} . d a \sim d e$ 'too, also; and (an intensive); both, and', daha 'so far, until now, still, yet, only; more, in addition; more, -er, a lot, -er; plus', dahi 'also, too, even' (Red pp. 163, 164); Khlj. ta tä (enklitisch) 'auch', taqï 'noch, mehr, wiederum' (DoTe80, pp. 197, 199); Trkm. dagï 'other, otherwise; more, still, yet; except; and others, et cetera' (BaKaXa68, pp. 242); Kzx. da de 'and, also, too; neither, nor; even, even if; -ever', tayi 'again', $t$. $d a$ 'again and again, more and more', tayisïn $t$. 'id., and so forth', tayisin tayilar 'etc., and so forth, and so on' (Shn66, pp. 72, 197); Kir. dagï tagï 'more, still, yet; also, as well, likewise, either; again' (Ju pp. 180, 188); Özb. tayin 'further, more; (yet) again' (CAHG p. 304; Bor59, p. 419); Trki tcexi 'yet, still, furthermore', $t$. hem

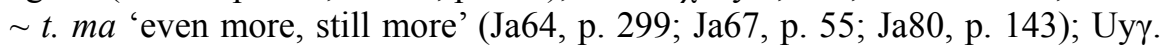
taqi (lit. obs.) 'still, yet; even' (Sch92, p. 164); Lop. tayi 'still, yet, more' (Mal56, p. 166); Sal. $t \dot{a} \sim t a \sim d \dot{a} \sim d a \sim d \partial$ 'aussi' (Kak62. p. 191), ${ }^{1} t a \sim d a \sim$

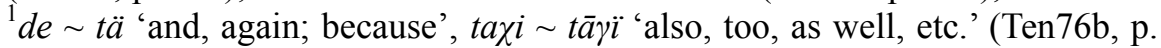
498); YogW $d a \sim t a$ 'same, again; and', taqo $\sim$ taqi 'more, still, yet; again' (Mal57, pp. 24, 108, 110), ${ }^{2} t a \approx{ }^{2}$ taye $\sim t a ' q y$ 'more, still, yet; again; and' (Ten76a, p. 211), $t a^{h} q i$ ' 'still, yet; also, moreover; or (in alternative questions)' $\sim t^{h} a^{h} q \ddot{i} \sim$ taqï $\sim$ taqo $\sim$ ta $q \ddot{y} y a($ Ro00, p. 370) • Tu. $>$ Mo. - YogE (Ro00 id.).

(37) Özb. tenogh (xxxii) tenobh [(read: tenogh)] [Haz. shanggak] 'fingernail'; mistake for *ternoy tirnoq? Or is it a similar development as in Uyy. where 
$-r C$ - $\rightarrow-C$ - (but in this word the $-r$ - is always preserved)? - Özb/Afgh. tirnaq 'nail' (Ja38, p. 229; $\rightarrow$ ); Af̌̃/Kbl do:rnây 'ongle' (Li57, p. 129), Afrs. dïrnax tïrnax 'id.' (DoHe89, pp. 36, 44); Mgh/Bdx. tïrnay [Pe. nāhon] 'id.' (HeHiThe79, p. 19968) - Eren 1999, p. 407; M38, p. 39*; Rybatzki, forthcoming 2017; TMEN §1182; VEWT p. 479 • Tu. (VIIIff) tïrnaq (?d-) 'a (human or animal) nail, or claw'. Survives in NE several languages tïr aq, Tuv. dïr [only 'Kamm' ( $\leftarrow$ taryaq), not with the meaning 'claw', which is dirbaq $(\leftarrow$ tarmaq) '(Finger)-Nagel, Klaue, Schramme, Harke' (Ölmez 2007, p. 139)]; SE Trki tïrnaq; SC Özb. tirnåq; NW most languages tïrnaq; SW Az., Trkm. dïrnak, Osm. ttrnak (C72, p. 551) - Tr. tirnak 'nail, fingernail, toenail; claw, hoof (refers only to the horny part of an animal's hoof); etc.' (Red pp. 704-705); Khlj. tïrna 'q 'Fingernagel', tïrnaq tïrna:q 'ganz klein, zerstümmelt' (DoTe80, p. 205); Trkm. dirnak '(finger)nail; clutch; hook' (BaKaXa68, p. 299); Kzx. tïnaq 'nail; claw, talon', t. otu 'hawkweed (Hieracium pilosella) $\rightarrow$ tïrnaqti 'sharp-clawed (of an eagle); (fig.) predatory' (Shn66, p. 207); Kir. tïrmak tïrnak 'nail, fingernail; claw, talon' $\rightarrow$ tïrmaktū 'beast, predator' (Ju pp. 294295); Özb/Buch. tinak 'a nail' vs. tirnak ‘a claw' (O05, pp. 54, 55), Özb. tirnåq 'fingernail, nail, claw, talon; hoof; child, offspring; device used to climb telephone poles (CAHG p. 321; Bor59, p. 435); Trki tïnaq tïrmaq 'claw, nail' (Ja64, p. 307; Ja67, p. 56; Ja80, p. 143); Uy\%. tirnaq '(phys.) fingernail, toenail; (zool.) claw, talon; (gr.) parenthesis, angle bracket' $\rightarrow$ tirnaqla- 'to claw, scratch', $\rightarrow$ tirnaqliq 'having nails, claws, or talons; spiked' (Sch92, p. 243); Lop. tïrmaq 'clutches; hook, crook, etc. [когти, крюк]' (Mal56, p. 179); Sal/Ili

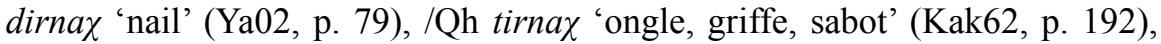

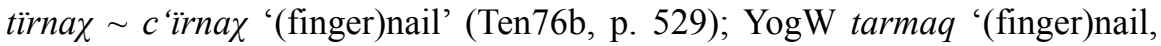
finger, claw', tïvaq (? tïraq) $\sim$ tïrmaq 'id., toe' tiryaq 'nail' $\rightarrow$ aramaq $\sim$ aramaq $^{h}$ 'ring finger' (perhaps $\leftarrow$ ara 'between' + tarmaq), $\rightarrow a^{h}$ temaq (speech of old people) $\sim a^{h}$ timaq 'little finger' (perhaps $\leftarrow a^{h} t i$ 'small' + tarmaq), $o^{h}$ rtamaq 'middle finger' (perhaps $\leftarrow o^{h} r t a$ 'middle' + tarmaq), pa sïrmik $\sim$ $\mathrm{pa}^{h}$ sïrmek 'thumb' (perhaps $\leftarrow$ paš 'head' + tarmaq) (Mal57, pp. 112-113, 128; Ro00, pp. 284, 330, 333, 370, 375; Ten76a, p. 211) • Tu. > Mo. - YogE (NuRo96, p. $50_{76}$; Ro00, p. 370)

(42, xxxviii) Özb. tirsak [Haz. (42) toqai (xxxviii) tokai] 'elbow' - Afs̃. dir säk dirsäy 'id.' (DoHe89, p. 44) - M38, p. 20*; Stachowski 2007, pp. 335-343; VEWT p. $481 \cdot$ Tu. (XI) tirsgäk no obvious etymology, although it looks like a dev. n.; 'elbow, a stye (in the eye)'. S.i.s.m.l. in all language groups, usually for 'elbow' but in some NE, NC languages 'knee joint' and in some 'stye'; in NE Tuv. diskäk; SW Az., Osm. dirsek but Trkm. tirsek (C72, p. 553) - Tr. dirsek 'elbow; bend, turn (in a line, road, or river); (pipe) elbow; prop, shore (placed at an angle)' (Red p. 189); Khlj. tīrsäk 'Ellenbogen' (DoTe80, p. 205); Trkm. tirsek 'elbow, knee' (BaKaXa68, p. 634); Özb. 'tirsak 'id.' (CAHG p. 322; Bor59, p. 436); Otü. tirsäk 'Ellbogen' (VEWT id.); Uyү. (Ø); Sal. tizek 'knee, elbow; lap', cf. ${ }^{2} t u ̈ z$ (Ten76b, p. 512); YogW $\dot{c}^{h} i k i n i k \sim c^{h} i_{k e n e k^{h}} \sim$ 
$c^{h} i k^{h} e n e k^{h} \sim$ čikenek $\sim$ (mountain dial.) tikenek 'elbow' (Ro00, p. 297) - Tu. > Mo. - YogE (NuRo96, p. 40 11 ; Ro00 id.).

(3) Özb. turdi [Haz. bida (kardan) bolda (kardan)] 'to jump' - Özb/Afgh. tur- 'to stand (up); to stay; to be' (Ja38, p. 231; $\rightarrow$ ); Afs̃/S dur:mi'š-äm '(auf)gestanden' (DoHe89, p. 30); Mgh/Bdx. turqäryän [Pe. bar-hāstan] 'aufstehen', tipturupti [Pe. ìstādan] 'stehen' (HeHiThe79, p. 220 620,621 ) - Berta 1996, pp. $377-$ 382; Erdal 1991, p. 865; M38, p. 32*; VEWT p. 500 - Tu. (VIII) ${ }^{1}$ tur- 'to stand', both in the sense of 'to stand upright' and 'to stand still'; with various extended meanings (C72, pp. 529-530) - Tr. dur-'(i) to stop; (ii) to last, continue to exist, endure; (iii) to continue to to be in one's possession, exist as a possession, to (still) have; (iv) to stand without doing anything; (v) to be or remain (at a place); (vi) to continue to be (in a specified condition); (vii) to suit, go, appear, look; (viii) to behave (in a specified way)'; ayakta dur- 'to stand, remain standing' (Red pp. 201, 56); Khlj. tur- 'stehen, aufhören, bleiben' (DoTe80, pp. 208-209); Trkm. tur- 'to rise, get up, stand up; to start, begin; to arise, spring up' (BaKaXa68, p. 645); Kzx. tur- 'to not go further, to stop; to be present, to be located; to cost; to stand; to stay, to live, to dwell' (Shn66, p. 205); Kir. tur- 'to stand; to get up, stand up, rise; etc.' (Ju pp. 268-269); Özb/Buch. tur- 'to stand, to rise, to stay' (O05, p. 56), /Qil. tur- 'to stand, to be, to get up' (Ja37, p. 53), /Urg. dur- 'to stand' (Dob74, p. 89), Özb. tur- 'to stand, to get up, to rise up; to be, to be found; to live, to abide; to wait; to stop; to stay; to last; to cost (CAHG p. 334; Bor59, p. 453); Trki tur- $\sim t u$ - $\sim$ tu- 'to be, to become, to stay, to stand, to abide, to remain, to keep fresh; to begin, to start, to rise, to stand up, to wait' (Ja64, p. 316; Ja67, p. 58), Uy\%. tur- '(i) to stand, stand up; (ii) to arise, get up; (iii) to live, reside; (iv) to stop, wait, stay; (v) to survive; (vi) to be stored or kept; (vii) to stick, be stuck; (viii-xix) various aspectual meanings' (Sch92, pp. 221-222); Trki/lli tür- 'to stand, dwell; (aspectual v.:) frequentive' (Ha91, p. 50); Sal. turu $\sim$ türü $\sim$ tira 'clair, tranquille (eau)' (Kak62, p. 192); YogW tur- 'to stand; to be, exist, etc. [Ru. находиться]; to live, exist [Ru. жить]' (Ma157, p. 125; Ro00, p. 378; Ten76a, p. 214) - Semantics recorded by Mackenzie are typical for Trkm., Özb,. Kir. and Uy $\gamma$.

(19) Özb. uranam $\sim$ (xvii) vranam [read: uranam] (kardan) [Haz. sabda (kardan)] 'to hit, strike' - Özb/Afgh. ur- 'to beat, strike' (Ja38, p. 233; $\rightarrow$ ); Mgh/Bdx. urgān [Pe.zadan] 'schlagen' $\rightarrow$ uriškān [Pe. jangìdan] 'kämpfen' (HeHiThe79, p. $221_{640,642}$ - cf. ( $\downarrow$ ) Mgh. vocabulary under hugutun; Berta 1996, pp. $408-$ 414 (esp. pp. 411-412); Erdal 1991, p. 624; M38, p. 7*; Sevortjan i, pp. 599601; VEWT p. 515 - Tu. (VIII) $u r$ - from the earliest period it had two distinct meanings linked by the fact that both involve use of the arms; (i) 'to put (something on something)', (ii) 'to strike (something or someone)', from which, esp. the first, a wide range of meanings has developed $\rightarrow$ (dev. v. refl.) (XI) urunwide range of meanings derived from the two basic meanings (C72, pp. 194195, 235) - Tr. Ø; Khlj. hur- 'spalten, zerschlagen, zerreißen' (DoTe80, pp. 135-136); Trkm. ur- 'to beat, hit, strike; to whip, flog, lace; etc.' (BaKaXa68, 
pp. 662-663); Kir. ur- 'to hit, strike, beat' $\rightarrow$ urun- 'to strike, hit, etc.' (Ju pp. 306-307, 308-309); Özb/Buch. ur- 'to strike' $\rightarrow$ uruš- 'to fight' (O05, p. 58), /Qil. ur- 'to beat, strike' (Ja37, p. 54), Özb. ur- 'to hit, to strike; to stab; to rush (away, up, etc.); to rain down hard; to beat (pulse); to destroy, to damage; to stuff into, to hide; to steal, to rob; to build (wall), to wall in, to close off; to put on, to bind with, to attach, to secure; to put down (food)' $\rightarrow$ urin- 'to throw or push about; to struggle, to strive (to do), to push, to try; to become worn out or dirty (clothing); to start to go bad (food)' (CAHG p. 341; Bor59, pp. 479-480); Trki $u r-\sim u j-\sim u \cdot-\sim o r-$ 'to beat, to knock, to strike, to hit, to throw, to mow, to reap, to shear, to cut (wheat, maize), to thrash' (Ja64, p. 324; Ja67, p. 59;

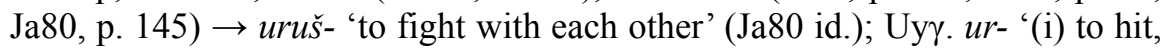
strike beat, assault; (ii) to strike (of clock); (iii) to pulsate, throb; (iv) to go all out' $\rightarrow$ uruš- 'to fight, struggle, war' (Sch92, pp. 581, 582); Lop. ur- 'to beat, hit, strike, smash, etc. [бить]' $\rightarrow$ uruš- 'to fight' (Mal56, p. 181); Sal/Ili vur'to beat' (Ya02, p. 178), /Qh vur- 'frapper, battre' $\rightarrow$ vural- 'être frappé', $\rightarrow$ vurəš- 'se battre', $\rightarrow$ vuryusa 'battoir' (Kak62, p. 192), ${ }^{1} u r-\sim^{1}$ vur- $\sim^{1}$ vuř- 'id. [Ru. бить]' (Ten76b, p. 534); YogW ${ }^{1} u r$ - 'to strike, etc. [спускать], to put, etc. [класть], to suppose, etc. [полагать]' (Mal57, p. 130).

(7) Özb. yakhshi [Haz. mughol (of man only); old form: mongol] 'good, beautiful' Özb/Afgh. yaxši 'good, agreeable, beautiful, excellent, well' (Ja38, p. 198; $\rightarrow$ ); Afš/Kbl yâxča 'bon, bien' (Li57, p. 120); Mgh/Bdx. yax̌̌i [Pe. hüb] 'gut', yaxšikil [Pe. hošs-gel] 'angenehm, schön', yaxši kün 'angenehmer Tag' (HeHiThe79, pp. 215464,474, 216 $6_{507}$ ) - M38, pp. 8*, 26*; TMEN §§1869-1870;

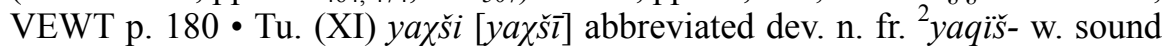
change $-k \grave{s}-\rightarrow-\chi \check{s}$-; not noted before XI. Although all the authorities use much the same Ar. words to translate this word and $\ddot{a} d g \bar{u}$, it is difficult to believe that they were originally syn. and it is likely that this word originally had some shades of meaning derived fr. ${ }^{2}$ yaqǐs- which distinguished it fr. $\ddot{a} d g \bar{u}$, 'suitable, pleasing, good looking' or the like. S.i.a.m.l.g. w. the usual phonetic changes, and largely syn. w. $\ddot{a} d g \bar{u}$, some languages using only one or the other but most both; in the latter case yaxšs has some meanings like 'good-looking' which $\ddot{a} d g \bar{u}$ has not (C72, p. 908) - Tr. yahşi (prov.) yakşi (prov.) 'good, nice; handsome, pretty, beautiful' (Red pp. 750, 751); Trkm. yagši 'good, kind, gracious' (BaKaXa68, p. 805); Kzx. yaqsï 'good, well; beneficial; decent; (fig.) rich (abundant)' $\rightarrow$ yaqsiliq 'good; benefaction; goodness, virtue' (Shn66, p. 97); Kir. yakšï 'good; (hist.) noble, honourable' (Ju p. 218); Özb/Buch. yakše yakšs 'good' $\rightarrow$ yakšalëk 'a blessing, good' (O05, p. 34), /Qil. yaұši 'good, all right' (Ja37, p. 49), Özb. yaxši 'good, fine; well' (CAHG p. 363; Bor59, pp.

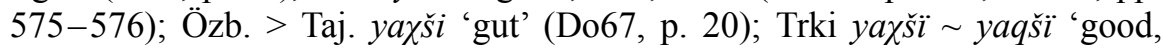
nice, comfortable, excellent, beautiful, delicate, all right, well', y.raq 'better'

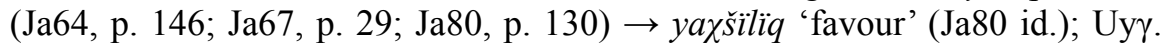
yaxši 'good, kind' $\rightarrow$ yaxšičaq 'good old boy; somebody who tries never to offend anybody', $\rightarrow$ yaxšisi 'it would be best', yaxši-yaman 'good and bad; allsorts', $\rightarrow$ yaxšila- 'to improve', $\rightarrow$ yaxšiliq 'goodness; kindness' $\rightarrow$ 
yaxšiliqčä 'graciously' (Sch92, pp. 776-777); Lop. yaqši 'good' (Mal56, p.

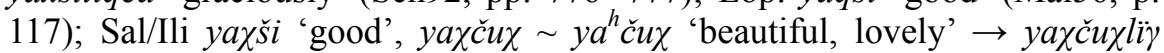

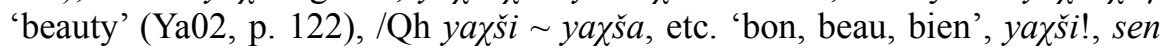

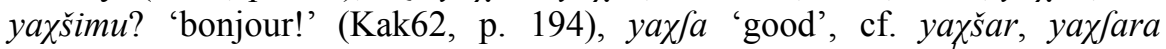
(Ten76b, p. 351); YogW yahšsi yaxši 'id.' (Ten76a, p. 182), ya ȟs yaxši 'id.' (Ro00, p. 393) - Tu. (Özb.), or Taj. > Yagh. yaxš̌ 'klar, offenbar' (Benveniste 1955, p. 160) - Tu. > Mo. - Bao. (Nugteren 1998, p. 692 26 ).

(20) Özb. yashundun (read: yashundum) (xviii) yashundum (kardan) [Haz. tasha (kardan)] '(to) hide' - Özb/Afgh. yešin- 'to hide oneself', yešinč̌ 'in secret, secretly' (Ja38, p. 200) - Eren 1999, p. 443; Erdal 1991, p. 866; M38, p. 29*; TMEN §1864; VEWT p. 192 - Uig. (VIIIff) yaš- 'to hide (oneself)'; n.o.a.b. $(\rightarrow)$, in modern languages displaced by the refl. f. of yašur $(\rightarrow), \rightarrow$ (dev. v.; caus.) Tu. (VIIIff) yašur- 'to hide (something)' and the like. S.i.a.m.l.g. with the usual phonetic changes; in SW only Trkm. yašir- (C72, pp. 975, 979) - Tr. yaşmak 'yashmak, yasmak, veil (tulle veil for a woman's face which leaves only the eyes exposed to public)' $\rightarrow$ yassmaklamak 'to put a yashmak on (a woman's) face, veil (a woman's) face with a yashmak', $\rightarrow$ yaşmakl '(woman) who is wearing a yashmak' (Red pp. 762-763); Trkm. yašir- 'to cover, shelter; to conceal, hide, veil' $\rightarrow$ yaširïn [яшыры:н] 'secret, esoteric, hidden, occult', $\rightarrow$ yašïr̈̈n- 'to hide, lurk' (BaKaXa68, p. 823); Kzx. yasïr- 'to hide, conceal' $\rightarrow$ yasirill- 'to be hidden', $\rightarrow$ yasïrïn- 'to hide; hide oneself', $\rightarrow$ yasïrïn 'secret, confidental; mysterious, enigmatic; secretly, surreptitiously, confidentially', yasïr̈ xabar ber- 'to inform confidentially', yasïrïnbaq 'hide and seek (play)' (Shn66, p. 96); Kir. yašïr- 'to hide, conceal, hold back' $\rightarrow$ yaširïn 'secret, private; secretly, privately; etc.', $\rightarrow$ yaširïn- 'to hide' (Ju p. 241); Özb. yašir - 'to hide, to conceal, to keep secret' $\rightarrow$ yaširin 'secret, secretly' (CAHG pp. 362-363; Bor59, p. 576); Trki yašur - 'to conceal, to hide' $\rightarrow$ yašurun

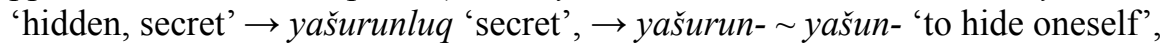
yašunup yat- 'id.; to be hiding' (Ja64, p. 151; Ja80, p. 131), Otü. yošunmaq 'verbergen' (LC18/19, p. 118); Uyy. yošur- 'to conceal, to hide, hold back' $\rightarrow$ yošurun, also: yošuruq 'secret; hidden, concealed, latent' $\rightarrow$ yošurunčä 'secretly, covertly', $\rightarrow$ yošurun- 'to hide, secrete, be concealed' (Sch92, p. 798); Sal/Ili yašin- 'to hide, conceal oneself' (Ya02, p. 125); YogW yas- 'to hide, go into hiding' (Mal57, p. 37) ya 's- ya'š- 'id.' (Ten76a, p. 183), $y a^{h} s-\left(\sim a^{h}{ }^{h-}\right)$

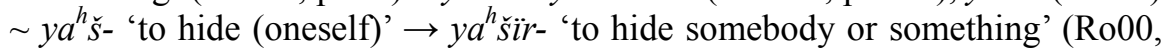
p. 393).

\section{(vi) Analysis of the Moyolī Vocabulary}

When Mackenzie was gathering his Moyolī materials in 1951, the language was not used any more in everyday life, but an old man could still remember some words, somehow known also to the rest of the community. Out of the 25 words thus collected, 
the great majority are of Mo. origin. Within 20 or so years, when Weiers (W72b, W73) collected materials under similar conditions to those of Mackenzie, the language situation had changed dramatically. Some wordlists present a mixture of Mo. and Tu. words, others consist of Tu. words only. Thus, within 20 years the knowledge of Moroli among certain parts of the Moghol population decreased greatly, some had forgotten the language altogether.

(XIII) Mgh. aman 'mouth' - Mgh/Mrv aman /Mrv amun /N, K, B ãmãn '(Mrv, N) Mund; (B) Eingang, (B, K) Verschluß' /Mr å:må:n /M amå:/n 'bouche, ouverture' [vs. Haz. daðān (W75b, p. 101)] (Li65, p. 277; Ra05, p. 22; W72a, p. 158), Mgh/L $\mathrm{L}_{1}$, Zi āmān 'mouth' (Iwa61, p. 85; W75a, p. 120) - Li62, pp. 16-17, Li64, p. 37; MYYC p. 105; Ry06, p. 117; Nu11, p. 269; TMEN §32 • MMoS/U/A ama/n [MTu. ayïz] 'Mund, mündlich' (Rybatzki, forthcoming b); EMoL aman 'mouth' (Ka09, p. 10), MoL ama/n, KhalL am/an 'id.' (Le60, p. 35); Ord. ama 'bouche, ouverture, orifice, passe dans une montagne, endroit ou duex objects se rencontrent, bord, environs, morceau carré d'étoffe dont chaque côté est égal à la largeur de la pièce dont le morceau est pris (unité de mesure); paroles proférées par quelqu'un' (Mos41, pp. 18-19); YogE aman 'mouth' (Nu11, p. 269); OirL aman 'mouth, opening', Kalm/SiddhiKür am cagān daxūl 'White Mouth the maid (of princess Möndüguu)' (DzagdsürenTsolo 1982, p. 312); Oir/D/Dz/T aman, /U àma/n, /Dz amman $\sim$ àma, /M åm 'bouche, ouverture, vallée, porte de fourneau', am nurzun 'occiput' (Ka58, p. 126); Kalm. amn 'Mund (auch im übertragenem Sinn); Mündung, Öffnung, Loch; Bergtal' (Ra35, p. 9) • Mo. > Tung. (Doerfer 2004, pp. 71-72, 74; MT $\S 12$; Rozycki 1994, p. 19).

(III) Mgh. arpa 'millet' · Mgh/KSn, M arfa $\sim / \mathrm{Le}, \mathrm{Mr}$; Me, KI, SB arpa $\sim / \mathrm{K}, \mathrm{N}$ orpa $\sim / \mathrm{LM}$ arpä $\sim / \mathrm{Z}_{\mathrm{O}}$ órpa 'Gerste' (DeHe93, p. 57; Li54, p. 128; W71, p. 164; ; W7a, p. 175; W72b, p. 5772) $\approx$ /Mrv arfsi /Mrv arfā 'id.' (Ra05, p. 23), Mgh/Zi arpa /Kun, $\mathrm{L}_{1}$ ärpah '(Kun, Zi) barley'; $\left(\mathrm{L}_{1}\right)$ 'Gerste' (Iwa61, p. 87; W75a.121), Mgh/Bdx. arpa [Pe. jou] 'id.' (HeHiThe79, p. 204 207 ) Doerfer 1993, p. 80; Hauenschild 1993, pp. 152-153 [KrimTat. arpa 'Gerste, Hordeum vulgare', Tr. arpa 'id.'; arpačiq soyan 'Schalotte, Allium ascalonium', Tr. arpacık soğanı 'id.' - SW, NW]; 1994, pp. 30-31; 2006, p. 18; Joki 1952, pp. 69-70; Li62, p. 17; Li66, p. 130; (?) M27, p. 11; M03, p. 10 (?); Nu11, p. 272; Rö pp. 201-202; Róna-Tas -Berta 2011, pp. 77-79; Rybatzki, forthcoming 2017; Ry06, p. 144; StachK08, pp. 9-13; TMEN §445; VEWT p. 27 - Uig. (VIIIff) arpa 'barley'; s.i.a.m.l.g. with minor phonetic variants; possibly an Indo-European (?Tocharian) 1.-w. $\rightarrow$ Tu. (XI) arpayan 'wild barley', a plant of the wild oats type; s.i.s.m.l. (C72, pp. 198, 200) - Tr. arpa 'barley; (slang) money' $\rightarrow$ arpack 'sty (on the eyelid); front sight (of a gun)', arpacıksoğanı 'shallot', $\rightarrow$ arpalık 'barley field; barley bin, granary for barley; etc.', arpasuyu 'beer' (Red p. 45); Khlj. arpa 'Gerste', yuš-arpasï 'Hafer; (wörtlich) Spatzengerste', arpa suvï 'Bier' (DoTe80, p. 82); Trkm. arpa 'barley' $\rightarrow$ arpagan 'a kind of grass? [мортук восточный]' (BaKaXa68, p. 52); 
Kzx. arpa 'id.', a. yarmasi 'pearl barley', a. talqanï 'fineground barley' (Shn66, p. 25); Kir. arpa 'id.' $\rightarrow$ arpakan 'id. [миртук восточный (read: мортук восточный)]' (Ju p. 69); Özb/Buch. arpa 'id.' (O05, p. 6), Özb. arpa 'id.', arpabådiyån '(bot.) anise' $\rightarrow$ arpayån '(bot.) myrtle?', arpapåya 'barleyfield, stalk of barley (CAHG p. 15; Bor59, p. 39); Trki árpa 'id., Hordeum distichum', árpa bádyán 'Anisum sativum', árpa khán (arpayán arpaxán) 'eine wildwachsende Avena-Art (Unkraut)' (LC11, p. 81; LC22, pp. 118-119), arpa $\sim a: p a \sim a \cdot p a \sim a \cdot p \varepsilon \sim a: p \varepsilon$ 'barley', a'pa bedjan 'Anisum sativum' (Ja64, p. 26), arpa arpe 'id.', a. bedijan 'anise' (Ja98, p. 67), arpa 'id.', a. oni 'Gerstenmehl', a. topač 'Gerstenbrot' (Ja67, p. 10); Uy\%. arpa 'id. (Hordeum)', arpabediyan 'sweet fennel (Foeniculum vulgare), used in Uyghur folk medicine', arpamiwisi 'Arbor vitae (Biota orientalis), used in Uyghur folk medicine', $\rightarrow$ arpixan $\sim$ apixan 'wild barley' (Sch92, pp. 3, 21); Lop. aipa $\sim$ arpa

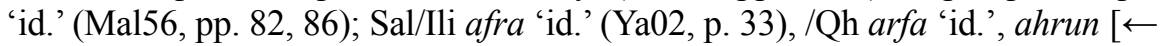
arfa un] 'farine d'orge' (Kak62, pp. 175, 176), arfa arf' $a \sim \operatorname{arf}{ }^{\prime} a$ 'barley', ax arfa 'white barley' (Ten76b, pp. 292, 293); YogW xarva 'certain cereal grains [какие-то хлебные зерна]', xarva darï 'millet' (Ch. činxur) (Mal57, p. 135), 'harva 'cereal grains, oat', harva vaš 'oat grain [зерна овса]' (Ten76a, p. 180), harwa $\sim$ hïwa $\sim$ xarwa $\sim$ xarba 'highland barley (grown in Tibet and Qinghai)' [Tu.] $\leftarrow^{*}$ harpa; initial $h$ is only attested in YogW (Ro00, p. 301) • Tu. ? $<>$ ? Mo. - MMoM arpai 'barley' $\sim$ U/A arbai 'id.', S ar[bai] 'rye' $~[\mathrm{Tu}$. forms] P arba A arpa 'barley' (Rybatzki, forthcoming b); MoL arbai, KhalL arwal 'id.' (Le60, p. 49); Ord. arwä 'id.' (Mos41, p. 31); YogE hrbai rbai 'id.' (Nu11, p. 272); Oir/D arwā [OirL arbai] 'id.' (Ka58, p. 127); Kalm. arwāa '(Ölöt, Torghut) Gerste, (Dörbed) Hafer' (Ra35, p. 15) • Tu. > Mo. - Bao.-Dgx. (Nugteren 1998, p. 6873) • Tu. $>$ Hung. (Róna-Tas-Berta id.) $\bullet$ Mo. $>$ Tu. (Khabtagaeva 2009, p. 156; TMEN id.) • (Early) Mo. > Tung. (TMEN id., Rozycki 1994, p. 20) - Ma. arfa 'Korn, insbesondere Gerste und Hafer' (Hauer p. 31).

(XXIII) Mgh. *bi, in: bikelata! 'Don't talk!' $\leftarrow$ bi $+(\downarrow)$ kelata - Mgh/Le bey $\sim /$ Le $b \bar{l}$ 'non pas, ne pas, ne (particule prohibitive)' $\sim / \mathrm{Mrv}, \mathrm{Mr}, \mathrm{M} b i$ 'lat. $n e$ ' $\sim / \mathrm{Z}_{\mathrm{O}}$ $b \check{\imath}$ 'Prohibativpartikel' (Li54, p. 129; Ra05, p. 24; W72a, p. 160 [be Negation vor Nomina $<$ Pe. $b i$ vs. $b i$ Negation vor Verben als Prohibitiv $\leftarrow$ Mo. $b u]$; W72b, p. 577 2 ), Mgh/Zi bikelan 'mute, speechless', /L 1 , 2 bi 'Prohibitiv 〈nicht' '(Iwa61, p. 91; W75a, p. 124, W77, pp. 121-123) - Li58, pp. 210211, 231-234 ${ }_{51}$; Li62, p. 22; MYYC p. 173; Nu11, p. 293; Poppe 1954, pp. 174-175; Rybatzki 2003a, pp. 79-80; 2003b, p. 384 $\bullet$ MMoM/S/U/P bu S $b \ddot{u} \sim \mathrm{A} b \ddot{u}(b u) \sim \mathrm{U} b u u \sim \mathrm{A} b \bar{u}$ [Cag. - $m A$-] 'prohibitive part.; do not!' (Rybatzki, forthcoming b); EMoL buu [= bü] '(prohibitive) do not, should not' (Ka09, p. 54); MoL buu bü̈ü, KhalL bü̈ 'prohibitive negation preceding imperatives' (Le60, p. 141); Ord. ${ }^{2} b \bar{u}$ 'particule prohibitive (emprunt fait à la langue littéraire)' (Mos41, p. 88).

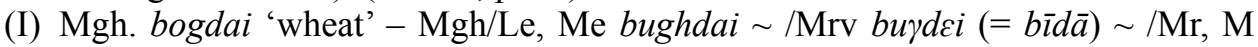

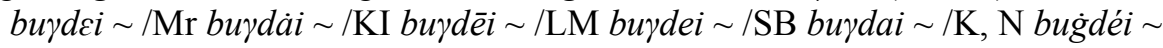




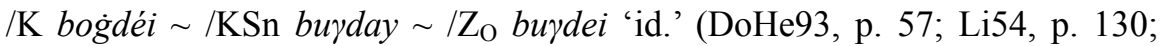
Ra05, p. 24; W71, p. 1645; W72b, p. 5773), Mgh/Zi burdai $\sim /$ Kun $b^{w} \gamma d^{a} y \sim$ /L $\mathrm{L}_{1}$ bugdai 'id.' (Iwa61, p. 93; W75a, p. 125), Mgh/Bdx burday [Pe. gandom] 'id.', buyday uramīz [Pe. derou] 'die Ernte einbringen' (HeHiThe79, pp. $204_{206}, 205_{223}$ ) || Doerfer 1992, p. 53; 1993, p. 80; Hauenschild 1993, p. 155; 1994, p. 40; 2006, pp. 23-24; Li62, p. 22; Nu11, pp. 292-293 [considers Mo. forms w. -G- as Tu.]; Rybatzki, forthcoming 2017; StachK08, pp. 89-96; VEWT p. 86 - Uig. (VIIIff) burday 'wheat'. S.i.a.m.l.g. with some phonetic changes (C72, pp. 312-313) - Tr. buğday 'id.' (Red p. 113); Khlj. buүda *

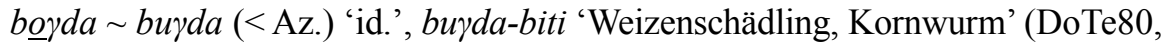
p. 94); Trkm. bugday 'id.' (BaKaXa68, p. 117); Kzx. biday 'id.' boydaq (local E) 'wheat of second year's crop (of last year's sowing)', küzdik biday 'winter wheat' (Shn66, pp. 54, 55, 129); Kir. 'buuday 'id.' (Ju p. 163);

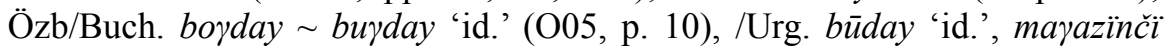
una būday wärgän 'the shopkeeper had given him wheat' (Dob74, p. 87), Özb.

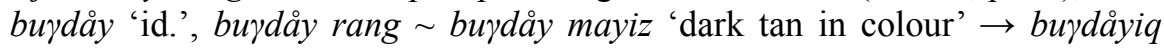
'(bot.) couch grass', $\rightarrow$ buydåykår 'wheat farmer; wheat-growing' $\rightarrow$ buydåykårlik 'wheat growing; wheat-growing lands, wheat fields', $\rightarrow$ buydåypåya 'wheat field; stalk of wheat', $\rightarrow$ burdåyzår 'wheat field' (CAHG p. 48; Bor59, p. 93); Trki buүdấi 'id.', kök baš b. 'eine Art Weizen', yázyrī b. 'Sommerwei-

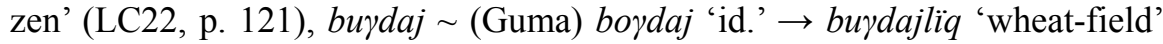

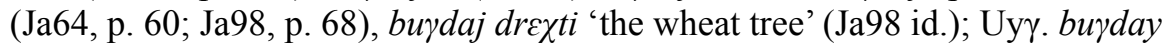
'id.' $\rightarrow$ buydayliq 'wheat field' (Sch92, p. 88); Trki/lli bürday 'id.' (Ha91, p. 39); Lop. boydaĭ 'wheat', different varieties: qütaĭ b., aq b., toĭmaq b., küzgü b.,

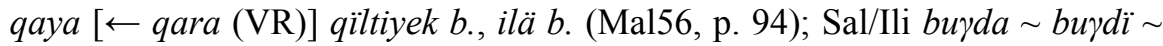
buydiy 'id.' (Ya02, p. 664), /Qh boyday būday poyta purta 'id.', būday čič $\chi$ 'bleuet' (Kak62, p. 177), boyde boydu 'id.', qyzyt boyde 'red wheat'

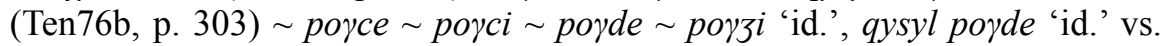
pōyïdï pōjudu 'id.' [< Mo.? (VR)] (id. 451) • MMoS bu'udai S büdai

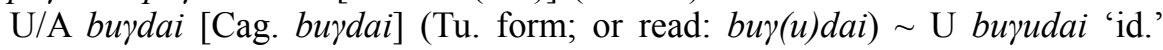
(Rybatzki, forthcoming b); MoL burudai buudai, KhalL buudai 'id.' (Le60, p. 131); Ord. büdä $\sim$ buiddä 'froment, blé; petites taches rousses qu'on remarque sur la robe des chevaux qui de gris sont devenus blancs en vieillissant' (Mos41, p. 90); YogE bugdüi 'wheat' (Nu11, pp. 292-293); [Oir/D budān 'blé, froment; gruan' [OirL budā] (Ka58, p. 130) is confused with *budaa/n 'groats, porridge',

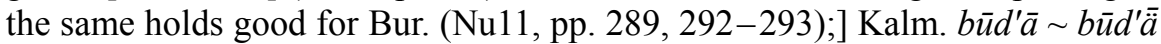
'(ursprünglich) Weizen; (jetzt) /Dörböt Same, Getreidekorn, Korn; /Ölöt Weizenkorn' (Ra35, p. 64) - Tu. > Mo. - Bao. YogE because of preserved -g- (Nugteren 1998, pp. 688-6898) $\bullet$ Mo. > Tu. - Otü. Sal. because of trisyllabic structure (Rybatzki, forthcoming 2017).

(VI) Mgh. chinagh 'wolf' - Mgh/Le chînà $\sim /$ Me china $\sim /$ Mrv činō $\sim / \mathrm{Mr}$, M činâ (činå:) /LM čena /N, S činó 'id.' (Li54, p. 131; Ra05, p. 25; W71, p. 16730; W72a, p. 163), Mgh/Zi činā $\sim /$ Kun čyna / $\mathrm{L}_{1}$ činna $\sim / \mathrm{L}_{1}$ čin̄ā? 'id.', $/ \mathrm{L}_{3}$ Ar. $\underline{\text { di }}$ 'b, Trkm. qürt, Mgh. čināa, Pšt. širmiš, Pe. gurg 'id.' (Iwa61, p. 96; 
W73, pp. 509 $63: 9$, 514; W75a, p. 127) - Doerfer 1965; 1992, p. 45; 1993, pp. 84-85; Li64, p. 35, Li65, p. 282; Li70, pp. 305-306; MYYC pp. 575; Nu11, p. 303; Poppe 1964, pp. 164-170, esp. pp. 164-166; Ry06, pp. 311-312; TMEN §191; Vovin 2007b, pp. 198-199 • MMoM cinō $\sim$ S cino $\sim$ A cinā [Cag. böri, MTu. qurt] U cina $\sim$ A canā 'id.', M gendü cinō 'Wolfsrüde', A deltü canā $\sim$ A deltü cinā [MTu. tälü qurt] 'hyena', (pl.) M cinōs 'Stammesname' (Rybatzki, forthcoming b); EMoL cina 'wolf' [Tib. l/ce spyang 'jackal'] (Ka09, p. 69); MoL cinu-a, KhalL čono/n 'wolf', MoL cinuncar 'jackal' (Le60, p. 190); Ord. čino čono 'loup' (Mos41, pp. 706, 712); YogE čona 'id.' (Nu11, p. 303); Oir/D/Kho/U čon, /Dz čon ${ }^{a}$ [OirL čonō] 'id.', /U čonon arsār dewel kīne 'de la peau du loup on fait des vêtement fourrés' (Ka58, p. 166); Kalm. čono 'Wolf; auch vom Menschen: wild, unverschämt' (Ra35, p. 444) • Mo. > Tu. (TMEN id.) - Sal. (Drimba 1976, p. 419; Kak62, p. 186) • Mo. $>$ Tung. (TMEN id.).

(IV) Mgh. ghajar 'land' - Mgh/Le ghajar 'plain' /Me ghajjar 'earth' /Mrv, M, Z yajar 'Erde, Land (Mrv); terre, pays (M, Z)' /Mr yaźar 'terre, pays' /KI yajär 'field' /LM rajár 'field' /LM raźar 'earth' /K, N gajár '(K, N) Erde, Boden; (K) Landstück' [vs. Haz. zamin (W75b, p. 101), cf. Pe. part of the manuscript p. 339] (Li54, p. 133; Ra05, p. 28; W71, p. 16836; W72a, p.

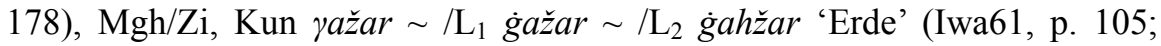
W75a, p. 135; W77, p. 135) - Li62, p. 41; MYYC p. 277; Nu11, p. 336; TMEN §253 • MMoM/S/U/P/A qajar [MTu., Cag. yer] 'terre, (la) Terre, sol, terrain, territoire, pays, endroit; $l i$ (mesure de longueur)' $\sim \mathrm{S}$ qajir 'earth' $\sim \mathrm{A}$ qacar A yajar 'Erde; Gegend, Ort, Landstrich', (pl.) S qajat U rajad (Rybatzki, forthcoming b); EMoL yajar 'earth, place; land, country' (Ka09, pp. 108-109); MoL yajar, KhalL gazar '(i) ground, soil, earth, land, territory; (ii) locality, region, district, territory, country, place (physically and figuratively), point; room (possibility of admission); way; (iii) office, institution; department, bureau; (iv) distance; Chinese mile (1,889.76 ft.)' (Le60, pp. 355-356); Ord. gajar 'sol, terre, place, endroit, terrain, champ, contrée; mesure de longueur = li chinois (environ 600 mètres); motif, raison, fait' (Mos41, p. 285); YogE gajar 'land, earth, soil, place' (Nu11, p. 336); Oir/D/Dz yazar yazr [OirL yazar] 'terre, place' (Ka58, p. 138); Kalm. yazr 'Erde, Land, Ort, Stelle' (Ra35, p. 148) • Mo. $>$ Tu. - YogW (NuRo96, p. $\left.68_{239}\right) \bullet$ (Recent) Mo. > Tung. (TMEN id., Rozycki 1994, p. 85) - Ma. (only) gajaraci gajarci [Mo. yajarci] 'Wegführer' $\rightarrow$ [Mo. rajarcilaqu] gajarcilambi 'den Weg zeigen, führen' (Hauer p. 175).

(XXIV) Mgh. hugutun 'to strike' - Mgh/Le hug 'heat (correct: 〈beat)' /Mrv úggüná

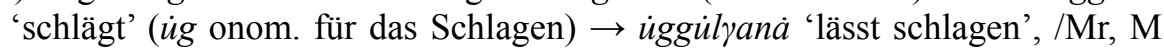

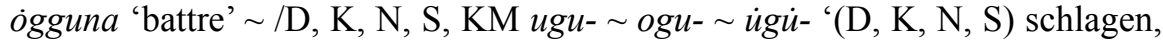
treten; (KM) werfen' $\sim / Z_{\mathrm{O}}$ ugutu 'schlage!', /K ugu ubda 'niederschlagen und zu Boden fallen (Lehnübersetzung von pe. zadaš habān daš)' (Li54, p. 134, Ra05, p. 41; W72a, p. 182; W72b, p. 577 21 ), Mgh/Zi, Kun úggú 'beat, hit'

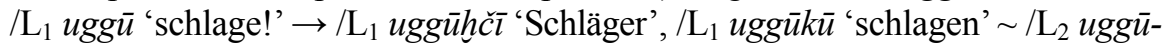


'stoßen, besiegen', /L 2 uggū 'Schläge' (Iwa61, p. 150; W75a, p. 165; W77, p. $187)$ - (个) Özb. vocabulary under uranam; (??) MYYC p. 577 (Oir/KököNuur $\chi o \gamma$ - 'to beat, hit, strike') - MMoA ügibe [Cag. urdi]; the verb occurs two times in MA and translates Cag. ur-, more common translations of $u r$ - in MA include delet-, bula·uda-, and oki- (Rybatzki, forthcoming b); (??) YogE hokpé 'to beat, hit' (Mannerheim 1911, p. 68) - According to Weiers (W72b id.) perhaps to be connected with Mo. $\ddot{o} g$-, but this is improbable because of the occurrences in MA. Prob., as first suggested by Ramsted (Ra05 id.) of onom. origin. The last opinion could also count for the Oir. and YogE forms.

(IX) Mgh. iljigan 'ass' - Mgh/Le eljigàn $\sim /$ Le eljigan $\sim /$ Mrv elǰigōn $\sim / \mathrm{Mr}, \mathrm{M}$

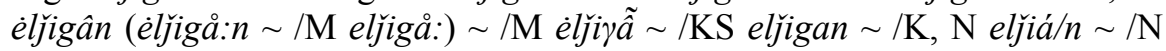
eljigẽ 'ass' (Li54, p. 132; Ra05, p. 27; W71, p. 165 1 ; W72a, p. 164), Mgh/Zi eljigan /Kun a $a^{y} l^{y}$ gn $\sim / \mathrm{L}_{1}$ ilğigan 'id.', $/ \mathrm{L}_{3}$ Ar. himār, Trkm. issak, Mgh. ilğigan, Pšt. ihrah, Pe. har 'Esel' (Iwa61, p. 101; W73, pp. 508 $62: 11$, 514, 517; W75, p. 139) - Li57, p. 117; Li64, p. 42; MYYC p. 256; Nu11, p. 328; Ry06, p. 101; TMEN §68 - MMoS/A eljige/n [MTu. ešäk] $\sim$ U eljigen $\sim$ A elšigen 'donkey'; A eme eljigen [MTu. tišsi ešäk] 'female donkey', A keherin eljigen 'wild donkey' (Rybatzki, forthcoming b); EMoL eljigen 'donkey, ass' (Ka09, p. 97); MoL eljige/n, KhalL ilžig ilžgen 'id.' (Le60, p. 311); Ord. eljüige 'âne' (Mos41, p. 235); YogE elǰiven aľ̈ijen 'donkey' (Nu11, p. 328); Oir/D elǰigin, /Dz èljigen [OirL eljige] 'id.' (Ka58, p. 137); Kalm. elj̆yna éljynn 'id.' [> Alt. äljigän] (Ra35, p. 119) • Mo. > Tu. (Ł; VEWT p. 40) - Sal. (Drimba 1976, p. 419), Tuv. (Khabtagaeva 2009, p. 161), YogW (NuRo96, p. 59 $9_{151}$; Ro00, p. 295; Ten76a, p. 634) - (Ancient) Mo. > Tung. (Grube 1900, p. 9; Rozycki 1994, p. 67; TMEN id.) - Jur. ehe [?read: e[i]xe or e[l]he] 'donkey' (Kane 1989, p. 222 ${ }_{436}$; Kara 1991, p. 151), Sib. eixeN 'donkey, ass' (Yamamoto 1969, p. $108_{2218}$ ), Ma. eihen 'Esel' (Hauer p. 124).

(XVIII) Mgh. khatun 'woman'; (16, xv) Özb. khatun [Haz. kaini] 'woman' (17,

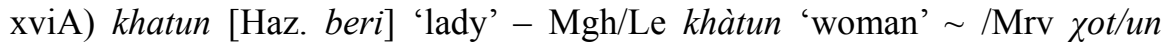

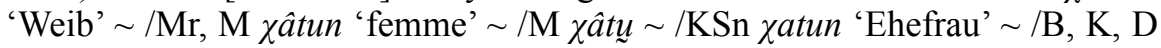

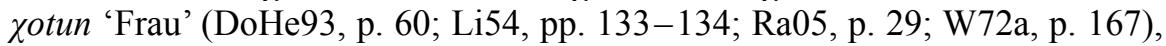
$\mathrm{Mgh} / \mathrm{L}_{1}$ hātūn 'id.', (pl.) /Zi xatut (Iwa61, p. 106; W75a, p. 137), Mgh/Bdx.

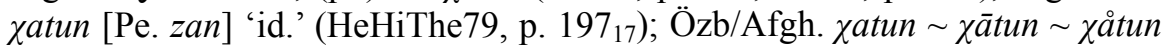
$\sim \chi$ å:tun 'wife, woman' $\rightarrow$ a atunlik $\sim \chi$ åtunlik 'marriage' (Ja38, p. 194; $\rightarrow$ );

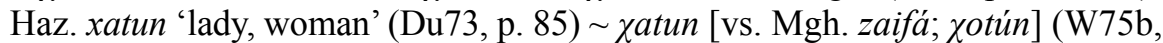
p. 100) /DZ khatu/n khåtu/n 'wife', khatun-i-awwal or kalo 'elderly wife' (Fe59, p. 48) - Doerfer 1992, pp. 43, 45, 48, 54; 1993, pp. 80, 82; 2004, pp. 464-465; Li62, p. 43; MYYC p. 335; Nu11, p. 405; Ry06, pp. 475-478; Rybatzki, forthcoming 2017; TMEN §1159; VEWT p. 157; Vovin 2007a, pp. 177-178 - Tu. (VIII) $\chi a$ atun 'lady', and the like. Survives in NE Tuv. kaday; SE Trki xatun $\sim$ xotun; NC, NW qatï; SC Özb. xåtïn; SW Az. ğadïn, Osm. kadin meaning only 'married woman, wife' with a slightly honorific flavour (C72, pp. 602-603); Uig. qatun qadun 'Frau, Gemahlin' (Yamada 1993, p. 274, Zieme 1992); UigS qatun kiši 'femme' (Li66, p. 165); CC qatun ұatun 
'Frau, besonders von Vornehmen; Ehefrau; Hausfrau, domina 〈Herrin, Gebieterin〉', qan qatunï 'Kaiserin, imperatris', soltan qatunï 'Königin, regina', tul xatun 'Witwe, vidua', qam qatun 'Zauberin, incantatrix' vs. epči 'Frau, Ehefrau; mulier «Weib, ursprünglich als Gegensatz zur Jungfrau, später als Gegensatz zum Mann`'; evdegi epči 'Dienerin, famula' (Grønbech 1942, pp. 89, 196, 225; Houtsma 1894, p. 78) - Tr. hatun '(i) woman; lady; (ii) a title meaning Mrs. or Miss (used after a first name); (iii) khatun, wife of a khan; (iv) wife' (Red p. 304) vs. kadın '(i) woman; (ii) woman who has lost her virginity; (iii) (prov.) title used after the name of elder women; (iv) (coll.) cleaning woman; maid; (v) good at housekeeping (id. p. 380)'; Trkm. xatïn [xā] '(hist.) woman, wife [Ru. женщина, жена]' (BaKaXa68, p. 692); Kzx. qatin 'wife, married woman' (Shn66, p. 262); Kir. katï 'woman, wife; elderly woman' (Ju pp. 360-361); Özb/Buch. katun 'woman, wife', k. al- 'to marry' (O05, p. 31),

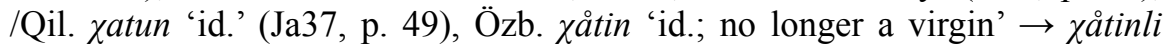

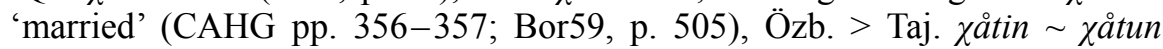

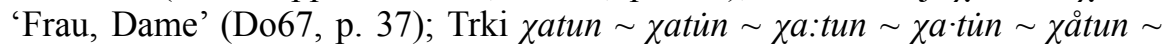

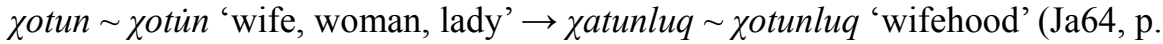

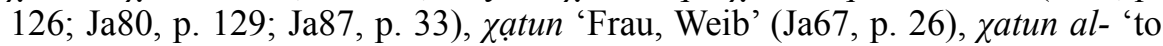

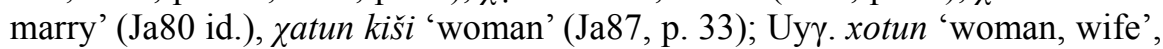
xotun-bala 'wife and children; family', $\rightarrow$ xotuntalaq 'wretch, scoundrel; bastard', $\rightarrow$ xotun-qizlar 'woman, womenfolk' [Özb. xåtin-qizlar], $\rightarrow$ xotunluq 'of xotun; abstract n. of xotun', xotunluqqa al- 'to choose as a wife' (Sch92, p. 380); Trki/Ili xatın 'woman, wife' (Ha91, p. 42); Lop. xotun 'woman, wife [Ru. жена]; lady, madam; Mrs. [госпожа]' (Mal56, p. 186); Sal/Ili yadïn 'woman' (Ya02, p. 102), /Qh qatun qāten qātun 'woman, wife', qatun kiš 'id.' (Kak62, p. 187; Ten76b, p. 463); YogW qatïn [Mo.] 'noble woman, wife of an important official person [жена важного чиновного человека] (Mal); wife; wife of a high ranking person (khan, official, chieftain), lady, queen (Ro)', cf. səždï, derbetsk (Mal57, p. 57; Ro00, p. 344), qatun 'wife of a prince; lady, madam, Mrs.' (Ten76a, p. 200) - Tu. > Mo. - MMoM/S/U/A qatun [MTu. qatun] $\sim \mathrm{M} / \mathrm{S} / \mathrm{U}$ qadun 'Frau, Gemahlin; angesehene, vornehme Dame', (pl.) $\mathrm{M} / \mathrm{U} / \mathrm{A}$ qatut $\sim \mathrm{U}$ qatud $\sim \mathrm{M}$ qadunt $\sim \mathrm{A}$ qatundun (pl.-gen.) (Rybatzki, forthcoming b); EMoL qatun 'empress, queen; lady, noblewoman, gentlewoman', qatun eke 'the queen mother', (pl.) qatud (Ka09, p. 232); MoL qatun, KhalL xatan 'lady, queen, princess; wife (hon.)' (Le60, p. 946); Ord. ' 'gatun 'dame, épuse de prince; nom du fleuve Jaune' (Mos41, p. 299); YogE gatan 'empress; wife; woman' (Nu11, p. 405); Kalm. 'xatn 'Gemahlin, Edelfrau, Königin' (Ra35, p. 172) - Mo. > Tu. - Yak. > Ewn. (Kałużyński 1995, p. 151; TMEN id.) • (Recent) Mo. > Tung. (MT §568; Poppe 1966, p. 196; Rozycki 1994, p. 135, TMEN id.) - Ma. katun 'Fürstin, Herrscherin, Königin, Kaiserin' (Hauer p. 304) • Mo. > Tib. k'at'un 'princess' (Laufer 1916, p. 494).

(XVII, XIX) Mgh. khushpas '(XVII) son, (XIX) boy' [i.e. 'sons, boys'] - Mgh/Mrv küšfat küšpat 'Kind' (Ra05, p. 31) [i.e. 'children', but not Pe. as considered by Ramstedt] /D kufb'a 'Kind' (W72a, p. 171), /Me reza kushpan 'children' 
(W71, p. 175 102, 103) [all these shortened forms] $\leftarrow /$ DŠ kavfib' $\wedge n$ 'Junges' $/ \mathrm{K}$ kovfiba 'Junge, Page; Sohn' /DŠ, KM kovfib'ın 'Kind, Junges' /K qovfib' ‘n 'id.' /KS köüšiban /KI kö̈̈šiba 'son', (pl.)/KI, LM kö̈̈šibat /LM kö̈̈šibad 'sons', $\rightarrow$ /K kavfib'^k^n 'Jüngelchen' (W71, pp. 164-1658; W72a, pp. 170-171) $\leftarrow$ Mgh. *kov/n 'Sohn, Kind' /Mrv köun /Le koun $\sim$ /Mr, M kəun /KS, LM kö̈̈n /Kd ka'u' n $\sim /$ Me kau $\sim /$ M kəu 'Kind, Sohn, Knabe, Junges' (DoHe93, p. 58; Li54, p. 137; Ra05, pp. 30-31; W71, pp. 164-1658), Mgh/ $\mathrm{L}_{1}$ kau 'Jungen, Buben (Kurzform von kaunāt)', $/ \mathrm{L}_{1}$ kaun 'Sohn', (p1.) / $\mathrm{L}_{1}$ kaunāt 'Jungen, Buben' (W75a, p. 142), $\rightarrow$ /N/K kavk'^ kavk'a 'Junge', (pl.) /Mrv köikàt 'Kinder' (Ra05, p. 30; W71 id.; W72a, p. 169) + Mgh. */ib' ' $/ n \sim{ }^{*} / i b^{\prime} \wedge$ 'Vogel' - Cleaves 1949, p. 116 130 ; Nu11, pp. 422-423, 488; Rybatzki, forthcoming 2017; W71, pp. 164-165 • MMoS

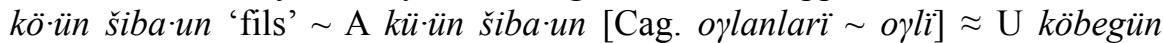
sibarun 'id.' (Rybatzki, forthcoming b); MoL keüked sibarut 'children' (Le60, p. 693); Ord. $k \dot{u}^{k} \chi e t ~ s ̌ i w \bar{u}$ 'les enfants' (Mos41, p. 435) $\leftarrow \mathrm{MMoM} / \mathrm{S} k \ddot{o} \cdot \ddot{u} / n$ 'fils; prince; grand prince' $\sim \mathrm{S}$ keü (or kö̈̈?) $\sim \mathrm{P} k e \cdot u / n$ 'son' $\sim \mathrm{A}$ keün $\sim \mathrm{A}$ kö̈̈n A kü̈n A kawun A kü•ün 'fils, garçon; Säugling (IMR)', (pl.) M/S kö̈üt (Rybatzki, forthcoming b); MoL keü küü (coll. form of köbegün), KhalL xü̈̈ 'son; young boy; interest' (Le60, p. 509); Ord. ${ }^{2} k \overline{\dot{u}}$ 'fills, garçon; se dit aussi d'un homme adulte, par mépris; s'emploie comme mot de tendresse en caressant un animal mâle; intérêt que rapporte une somme d'argent' (Mos41, pp. 433-434); YogE (only in compunds) haja-kün 'grandson', kü:n hkon 'chil-

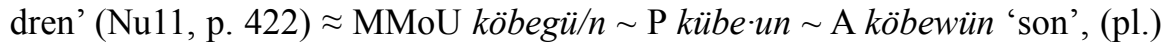
U köbegüd (Rybatzki id.); EMoL köbegün ‘son, boy', (pl.) köbegüd (Ka09, pp. 155-156); MoL köbegün, KhalL xübü̈̈n 'son, boy; pawn (chess)' (Le60, p. 494); Ord. köwögūn [!] '(emprunté à la langue litt. - dans un conte) fils',

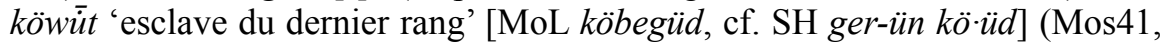
p. 433); Oir/D/Kho köwün /Dz küwün [OirL kübü̈̈n kübö̈̈n], /D köwünēs yarsan köwün 'petit-fils', (pl.) /Dz küwü̈d [OirL kübö̈̈d] 'fils, garçon' (Ka58, p. 149); Kalm. köwün 'Sohn, Knabe; Bauer (im Schachspiel); Kopie, Abschrift; Zinsen (selten)' (Ra35, p. 242) + [Khit. šawa 'falcon' (Doerfer 1993, pp. 8485; Ligeti 1964, p. 288), 〈ś.au.a〉, (Liaoshi) *shauwa 'id.' (Kane 2009, p. 97);]

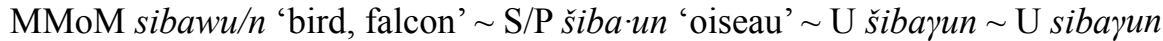
'id.' $\sim$ A suwān 'predatory bird' $\sim$ A šibān $\sim$ A šibawun $\sim$ A *sibau $/ n(\rightarrow$ sibauci) $\sim$ A šibaun $\sim$ A šibūn [Cag. MTu. quš $\sim$ Cag. tawuq] 'bird', (pl.) S

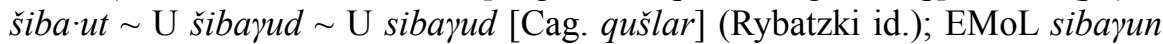

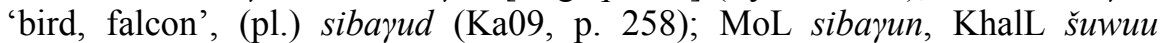
'(i) bird, fowl; (ii) child' (Le60, p. 693); Ord. šiwu 'oiseau' (Mos41, p. 626); YogE šu:n 'id.' (Nu11, p. 488); Oir/D/Dz šuwūn [OirL šibuun] 'id.', /D

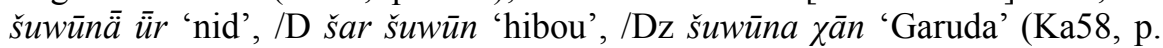
159); Kalm. šowūn 'Vogel', šar šs. 'Ohreule' (Ra35, p. 366).

(XII) Mgh. qabar 'nose' - Mgh/Le kabr /Me qubar /Mrv, Mr, M qabar /M qaßar /KI kabar /K qیb'ır 'nose' [vs. Haz. bīnī damā $\gamma$ (W75b, p. 100)] (Li54, p. 135; Ra05, p. 31; W71, p. 172 73 ; W72a, p. 176), Mgh/Zi, Kun, $\mathrm{L}_{1}$ 
qabar '(Zi, Kun) nose; $\left(\mathrm{L}_{1}\right)$ Nase, Schnauze' (Iwa61, p. 122; W75a, p. 149) Li62, p. 40; MYYC p. 322; Nu11, p. $396 \cdot \mathrm{MMoM} / \mathrm{S} / \mathrm{A}$ qabar [Cag. MTu. burun] 'nose' (Rybatzki, forthcoming b); EMoL qabar 'id.' (Ka09, p. 222); MoL qabar qamar, KhalL xamar '(i) nose, muzzle, snout, trunk of an elephant; (ii) anything suggestive of the nose in shape or structure; spur of a mountain between valleys or ravines; cape; angle; partition (as in a room); adjacent' (Le60, p. 895); Ord. xamar 'nez, naseaux, narines, extrémitée pointue, pointe, anneau qu'on met au nez des bœufs vicieux, cheville qui traverse le nez des

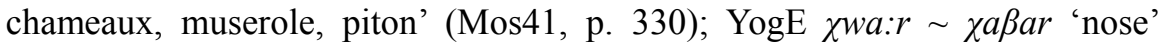

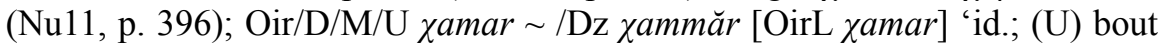

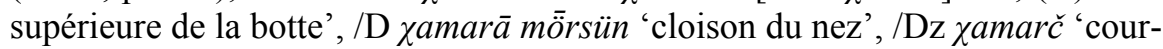
roie passant dans les naseaux du cheval' (Ka58, p. 142); Kalm. $\chi a m r$ 'Nase' (Ra35, p. 164) - (Recent) Mo. $>$ Ma. ${ }^{2}$ kabari 'Auswuchs an der Nase von Maultieren und Pferden' (Hauer p. 298; Rozycki 1994, p. 129).

(XX) Mgh. qiz 'daughter' - Özb/Afgh. qiz 'daughter, girl' (Ja38, p. 219; $\rightarrow$ ); Afš/FX/S qüz 'daughter' (DoHe89, p. 42) - Golden 2001, p. 51; TMEN §1601; VEWT p. 269 • Tu. (VIII) ' qüz basically 'girl, unmarried woman', but often used with a more restricted meaning 'daughter, slave girl', and the like. Although the main entry in Kaš. is $q \ddot{z} z$, the original form was certainly qizz, SW Trkm. still $\gamma \bar{z} z$; c.i.a.p.a.l. (C72, pp. 679-680) - Tr. klz 'girl; daughter; virgin, maiden; (playing cards) queen' (Red p. 431); Khlj. $q q^{i} z \sim q \bar{l} z$ 'Tochter, Jungfrau' $\rightarrow$ qīzluq 'Jungfräulichkeit' (DoTe80, pp. 176, 177, 178); Trkm. gïz [гы:3] 'girl, female child; maid, maiden; daughter' (BaKaXa68, p. 227); Kzx. qüz 'daughter; girl, little girl, young girl', q. bala 'a little girl', q. üzatqandayi toy 'wedding' (Shn66, p. 271); Kir. kïz 'girl, lady; maid, maiden; bride' (Ju p. 476); Özb/Qil.

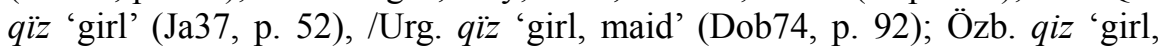
daughter; virgin, maiden' $\rightarrow$ qizalåq 'young girl' (CAHG p. 243; Bor59, p. 610), Özb. > Taj. qiz 'Mädchen' (Do67, p. 45); Trki qüz 'girl, maid, daughter', qïzbala qïzvala 'girl, daughter', $\rightarrow$ qïzliq 'daughterhood' (Ja64, p. 249; Ja80, p. 139), qiz 'Mädchen, Tochter, Jungfrau', orda q. 'Hofdame' (Ja67, p. 46); Uy\%. qiz 'girl, unmarried woman; daugher' $\rightarrow$ qizčaq 'young girl' (Sch92, p.

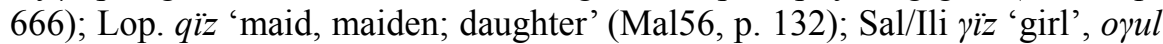
yiz 'boys and girls' (Ya02, p. 107), /Qh qiz qaz 'jeune fille' (Kak62, p. 188), quiz $\sim q y z \sim q^{\prime} y z$ 'daughter; girl, lady' (Ten76b, pp. 466, 467); YogW qizz 'id.', oyul qizdarï 'children' (Mal57, p. 62), qyz $\sim \gamma y z \sim{ }^{2} q y s$ 'girl, lady, maid, maiden; daughter', qyz oyot 'children' (Ten76a, p. 201), qiz 'girl; daughter; unmarried young woman', $q$. oyul 'children, daughters and sons', eyin q. 'niece', $k i^{\text {h }}$ ciq $q$. 'small girl, young girl', pezïk $q$. 'elder girl, young woman', sunzï $q$. 'granddaughter', qüzaqa 'elder sister' ( $\leftarrow$ qïz + aqa 'elder brother'), qïztar 'girl, little girl', qïztarqaš 'little girl' (Ro00, pp. 347-348) • Tu. 1.-w. in Mgh., otherwise not attested in Mo. languages, cf. TMEN (id.).

(XIV) Mgh. qol 'hand', (XV) $(\downarrow)$ pai-i qol 'finger nail' - (MghL *qol $\rightarrow)$ /Zi qoltuq $\sim /$ Kun $q^{w} l t^{w} q \sim / \mathrm{L}_{1}$ qultuq '(Zi, Kun) arm; $\left(\mathrm{L}_{1}\right)$ Oberarm, Arm; Tatze' (Iwa61, p. 127; W75a, p. 154); Mgh/Bdx. qol [Pe. dast] 'Hand', qol $\sim$ dastas $[\mathrm{Pe}$. 
dastās] 'Handmühle' (HeHiThe79, pp. 19961, 205 236 ); Mgh/Mackenzie < Tu., cf. Özb/Afgh. qol 'hand, paw (wolf, in tales)', bar qolliq 'with one hand' (Ja38, p. 219; $\rightarrow$ ), otherwise Mgh. gar yar 'Hand' [vs. Haz., Pe. dast $\sim$ dest $\sim$ dist (DoHe93, p. 57; W71, pp. 166 $15,171_{70}$; W72a, p. 165; W75b, p. 101); Afš/FX yol 'Ärmel' (DoHe89, p. 42) - Rybatzki, forthcoming 2017; TMEN $\S \S 1571,1575$; VEWT p. 276 • Uig. (VIIIff) qol properly 'the upper arm', as opposed to älig 'the forearm, hand', but in some modern languages more generally 'the arm' and even 'the hand'; also has various metaph. meanings, e.g. 'a wing' of an army [this $<$ Mo. (VR)]. S.i.a.m.l.g. $\rightarrow$ Uig. (VIIIff) qoltuq 'armpit'; s.i.s.m.l. (C72, pp. 614-615, 619) - Tr, kol 'arm; sleeve; etc.' $\rightarrow$ koltuk 'armpit; armchair; etc.' (Red pp. 438, 440); Khlj. qol 'Arm' $\rightarrow$ qoltuq 'Achselhöhle' (DoTe80, p. 178); Trkm. gol [гол] 'hand, arm' $\rightarrow$ goltuk 'armpit' (BaKaXa68, pp. 185-186); Kzx. qol 'hand, wrist, arm; foreleg (of animals), gorge; army, (mil.) detachment [third group $<$ Mo. (VR)]' $\rightarrow$ qoltiq 'gulf, bay; armpit' (Shn66, pp. 265-266); Kir. ${ }^{1}$ kol 'hand [рука, кисть руки]; (or: aldïkï $k o l)$ foreleg; finger; handwriting' $\rightarrow$ koltuk 'armpit, place under the armpits [место под мышками]' (Ju pp. 395-396, 398-399); Özb/Buch. kål köl [!] 'hand', kålkap $\sim$ kålteri 'gloves' $\rightarrow$ kåltuk $\sim$ koltuk 'bundle' (O05, p. 34), Özb. qol 'arm \& hand; finger; writing, hand', qolqåp 'mitten, glove', $\rightarrow$ qoltiq '(i) armpit, underarm; (ii) bay, gulf, inlet' $\rightarrow$ qoltiqbardår 'supporter, helper' (CAHG p. 244; Bor59, pp. 635-636); Trki qol 'Arm, Hand, Finger, Zehe' (LC11, p. 95), qol 'hand', (Guma) q. gošt 'meat of a front leg' (Ja64, p. 251; Ja67, p. 47; Ja96, p. 43 115 ) qot 'Handknochen' (Me55, p. 101) $\rightarrow$ qolda- 'to care of, to lead by the hand', $\rightarrow$ *qolla- $\rightarrow$ qollaš- 'to shake hands, to make a bet', $\rightarrow$ qoltoq 'arm-pit', $\rightarrow$ qolvay 'bundle' (Ja64 id.), $\rightarrow$ qollašlay 'Verlobte' $\sim$ qollašli $\gamma$ 'Verlobte; Braut' (Ja67, p. 47), qol 'hand', q. ber- 'to give the hand, q.ïdïn tut- 'to take someone by the hand' $\rightarrow$ qoldaš 'companion' (Ja80, p. 139); Uy\%. qol 'hand, arm, finger; financial conditions; handwriting; free or spare time; cooking' $\rightarrow$ qoltuq 'armpit; bay, bend' $\rightarrow$ qoltuqla- 'to support with one's hands; to tuck under one's arm', $\rightarrow$ qoldaš 'attendant of bride or groom', $\rightarrow$ qolwaq 'small boat' $\rightarrow$ qolwaqci 'sailor', $\rightarrow$ qolqap 'glove, mitten', $\rightarrow$ qol-qanat 'arms', $\rightarrow$ qolyazma 'manuscript', $\rightarrow$ qolyayliq 'handkerchief', $\rightarrow$ qolla- 'to approve, endorse, support' $\rightarrow$ qollan- 'to adopt, take' $\rightarrow$ qollanma 'handbook, guide', $\rightarrow$ qolluq 'finger, hand', $\rightarrow$ qolmu-qol 'in unison, simultanously; with one's own hands' (Sch92, pp. 645-647); Trki/lli qol 'hand, arm' (Ha91, p. 45); Lop. qol 'hand' $\rightarrow$ qoltuq 'armpit; n. pr.' (Mal56, pp. 128129); Sal/Ili ' ${ }^{1}$ ol 'arm' (Ya02, p. 108), /Qh qol yol 'id.' (Kak62, p. 188), ${ }^{1}$ qot 'id.' (Ten76b, p. 464); YogW ${ }^{3}$ qol 'side, flank, hip [сторона, бок]; hand [рука]', sol $\mathrm{\gamma ol}$ 'left-hand side [левая сторона]', altï qollï purqan 'six-armed Buddha [шестирукий бурхан] $\rightarrow$ qoltïq 'armpit' (Mal57, pp. 57, 58), qot 'hand' $\rightarrow$ qottyq 'id.' (Ten76a, p. 200), 'qol 'arm', ki' ciq q. 'fore arm', ya $a^{h}$ a q. 'upper arm' $\rightarrow q o^{h}$ ltïq $\sim q o^{h}$ ltï $^{h} \sim q^{h} o^{h}$ ltï $^{h}$ 'id.' (Ro00, p. 348) • Otherwise not attested in Mo. languages (Rybatzki, forthcoming id.; TMEN id.). 
(XXIII) Mgh. *kelata 'talk!', in: bikelata 'Don’t talk!' $\leftarrow(\uparrow)$ bi + kelata $-\mathrm{Mgh} / \mathrm{Le}$ kela 'speach' /Le, Mr, M; B, S, K kelan '(Le) tongue; (Mr, M, B, S, K) langue, parole, mot' $\sim /$ Mrv kelän 'Zunge' $\sim / \mathrm{M}$, MS kela $\sim /$ KI kelān 'mouth' [vs. Haz. zibū 'Zunge' (W75b, p. 101)], Mgh/Mrv keland 'sagt' /B, D, K, S kela- kelä- kele- 'sprechen, reden' (Li54, p. 136; Ra05, p. 30; W72a, p. 70), Mgh/Zi kela 'tongue' $\sim /$ Kun $k^{y} l^{y} n$ 'id.' $\sim /$ Zi kelan 'speech, saying' $/ \mathrm{L}_{1}$, $\mathrm{L}_{2}$ kilan ' $\left(\mathrm{L}_{1}\right)$ Zunge, Sprache, Wort, Rede; $\left(\mathrm{L}_{2}\right)$ Bericht; Geheiß', (pl.) $/ \mathrm{L}_{1}$ kilat 'Zungen, Sprachen', $\rightarrow / \mathrm{L}_{1}$ killahčì 'Sprecher', $/ \mathrm{L}_{1}$ killakī 'sprechen, sagen' (Iwa61, p. 111; W75a, pp. 142-143; W77, p. 153), /Zi bikelan 'mute, speechless' (Iwa61, p. 91) [ $\approx$ MMoA kelegei [Cag. kelegei] (Rybatzki, forthcoming b), Mo. kelegei 'stotternd, stumm' $\leftarrow$ kele + ügei 'sprachlos' (MT §87)] Clark 1977, pp. 136-138; Li62, pp. 49-50; Li70, pp. 292-293; MYYC pp. 340-341; Nu11, pp. 409-410; Ry06, pp. 553, 557; TMEN §335; VEWT pp. 248, $249 \cdot \mathrm{MMoM} / \mathrm{S} / \mathrm{U} / \mathrm{A}$ kele- [Cag. ayt- sözle-] 'dire, parler' (Rybatzki id.); MoL kele-, KhalL xelex 'to utter words, express in words; to speak, say, tell, narrate' (Le60, p. 447); Ord. kele- 'dire, parler, raconter; dire du mal, faire des reproches, réprimander' (Mos41, p. 411); YogE kel- 'to speak', *kele- $\leftarrow$ *kelele- (Nu11, p. 410); Kalm. kel $\chi^{2}$ ' '(i) sagen, sprechen; (ii) versprechen, verloben (die Kinder)' (Ra35, p. 223) • MMoM/U kele/n '(M) Zunge; Rede, Worte, Nachricht, Sprache; (U) Sprache' $\sim$ S/A kelen [Cag. MTu. til $\sim$ Cag. zaber] '( $\mathrm{S}, \mathrm{A} / \mathrm{VdI})$ langue; (A/IM) Erzählung, Geschichte; (A/AL, Ras) Zunge' A kele 'parole', A kelene uran [MTu. tilavuz] 'eloquent' (Rybatzki id.); EMoL kele 'tongue, language' (Ka09, p. 143); MoL kele/n, KhalL xel/en '(i) tongue; (ii) anything resembling a tongue; bell clapper, tongue of a buckle, etc.; (iii) language, dialect, speech' (Le60 id.); Ord. kele 'langue, langage, nouvelle' (Mos41 id.); YogE kelen 'tongue; speech, language' (Nu11, p. 409); $\mathrm{Oir} / \mathrm{D} / \mathrm{Dz} / \mathrm{U}$ kelen [OirL kele/n] 'langue, language', /D šin kelend ordžēn 'commencer à parler (petit enfant)' (Ka58, p. 147); Kalm. keln 'Zunge, Sprache, Nachricht' (Ra35, p. 224) $\rightarrow$ MMoM/S/U/A kelele- 'to say, speak' (Rybatzki id.); EMoL kelele- 'to speak, talk' (Ka09 id.); MoL kelele-, KhalL xellex 'to speak' (Le60, p. 448) $\approx$ Ord. keled ${ }^{k} \chi e$ 'dire (action de courte durée)' (Mos41 id.) • Mo. > Tu. (Schönig 2000, pp. 120-122, esp. 121-122; TMEN id.) - Özb. $>$ Taj. (Do67, p. 32), Kzx. (Shn66, p. 123), Sal. (Drimba 1976, p. 420) • (Recent) Mo. > Tung. (MT §§87, 518; Rozycki 1994, p. 104; TMEN id.): Ma. hele 'Sprachvermögen' helen 'der Sprache des feindlichen Landes Kundiger, Agent, Spion; für hele' (Hauer p. 225).

(VIII) Mgh. morin 'horse' - Mgh/Le; Mrv; Mr, M morin '(Mrv, Mr, M) horse; (Le) horse, mare' $\sim /$ KSn, Me mori $\sim /$ Le morn $\sim /$ LM murin $\sim /$ Kd morin $\sim / \mathrm{B}, \mathrm{D}$, $\mathrm{K}, \mathrm{N}, \mathrm{S}$ mori/n 'horse', /S morinsowar [Mo. Pe.] 'Reitpferd' $\approx / \mathrm{Z}_{\mathrm{O}}$ muri' 'Esel' (DoHe93, p. 58; Li54, p. 138; Ra05, p. 33; W71, p. 16510; W72a, p. 172; W72b, p. 578 29 ), Mgh/Zi murin $\sim /$ Kun $m w r^{y} n \sim / \mathrm{L}_{1}$ murin 'horse', $/ \mathrm{L}_{3} \mathrm{Ar}$. hail, Trkm. àt, Mgh. murin, Pšt. as (sic), Pe. asp 'id.' (Iwa61, p. 117; W73, pp. 50963:3, 515, 516; W75a, p. 146) - Hauenschild 1996, p. 181; Janhunen 1996, 1998; Li62, pp. 54-55; Li65, p. 281; MYYC p. 487; Nu11, p. 446; Ry06, pp. 
615-616; Rybatzki, forthcoming 2017; TMEN $\$ 374 \cdot \mathrm{MMoM} / \mathrm{S} / \mathrm{A}$ mori/n [MTu. Cag. at] U/P morin $\sim \mathrm{S}$ muri 'Pferd; Jahr des Pferdes' (Rybatzki, forthcoming b); EMoL morin 'horse, steed' (Ka09, p. 184); MoL mori $/ n$, KhalL moŕ $\sim$ morin 'horse, equine; (chiefly in names of plants and animals) great, big, large (cf. üker); knight (in chess)' (Le60, p. 543); Ord. mori 'cheval' dans quelques expressions, mori a le sens de 'grand', cf. temé, $\dot{u}^{k} \chi e r$ (Mos41, p. 467); YogE mo:ra mo:ra 'id.' (Nu11, p. 446); Oir/D morin /Kho mor /Dz mör /U mörn [OirL morin mörin] 'étalon, cheval' (Ka58, p. 151);

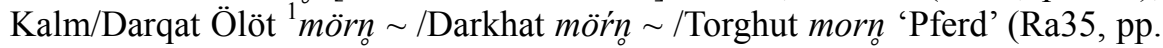

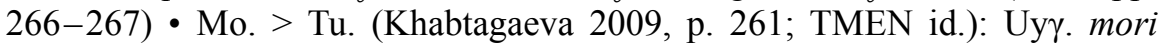
'(geo. n.) Mori (Mulei), Kazakh autonomous county in Xinjiang (43.49N 90.11E). Established in 1920, changed to autonomous county in 1958. Population (1982): 77299 (14335 Kazakhs)' (Sch92, p. 895) • (Ancient) Mo. > Tung. (Castrén 1856, pp. 96, 134; Kałużyński 1971b, p. 28; MT §51; Rozycki 1994, p. 159; TMEN id.; Yin 1995, p. 192) - Jur. muri 'horse' (Kane 1989, p. 216 410 ); Sib/Ili mori/n moriń mörin 'Pferd' (Kałużyński 1977, pp. 226-227), [mörin < Oir.-Kalm. (VR)] moriN 'id.' (Yamamoto 1969, p. 1072182); Ma. morin 'Pferd; das zyklische Zeichen wu (午)' (Hauer p. 349) • For the semantics of $\mathrm{Mgh} / \mathrm{Z}_{\mathrm{O}}$ cf. the remarks $(\downarrow)$ under tiva.

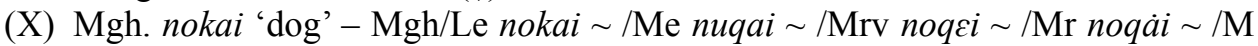

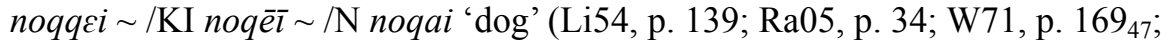
W72a, p. 174), Mgh/Zi noqai /Kun $n^{w} q^{a} y \sim / \mathrm{L}_{1}$ nuqai 'id.', / $\mathrm{L}_{3}$ Ar. kalb, Trkm. ìt, Mgh. nuqai, Pšt. aspai (sic), Pe. sak (sic) 'id.' (Iwa61, pp. 119-120; W73, pp. 511 $65: 1,515$; W75a, p. 148) - Doerfer 1992, p. 48; 1993, pp. 80, 84; Li62, p. 58; Li65, p. 282; MYYC p. 513; Nu11, p. 462; Poppe 1964, pp. 166167; Rybatzki, forthcoming 2017; Ry06, p. 626; Thomas 2011; TMEN §386; VEWT p. 354; Vovin 2007b, pp. 199-200 • Kit. 〈ńi.qo〉 *nieho 'dog' (Kane 2009, p. 93); MMoS/U/A noqai [MTu. it] P noqoyi $\sim$ S nuqu $\sim$ A noyai $\sim$ A noqā 'Hund', S/U noqai jil '11. Jahr des Zyklus', U bing noqai jil (Rybatzki, forthcoming b); EMoL noqai 'dog' (Ka09, p. 198); MoL noqai, KhalL noxoi 'dog; for superstitious reasons substitutes for 〈wolf) ( inu- $a)$ in certain contexts; one of the 12 animal of the animal cycle; swindler, cheat; crafty, cunning, tricky', noqai jil 'eleventh year in the animal cycle', noqai čay '(Dog hour),

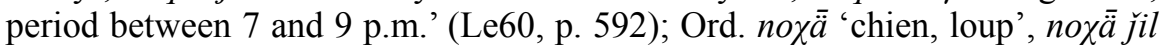
'la onzième année du cycle de douze', noxä sara 'la neuvième lune (d'après les calendriers astrologiques)', nox $\bar{a}$ c $a \gamma$ 'de 7 à 9 h. du soir' (Mos41, p. 497);

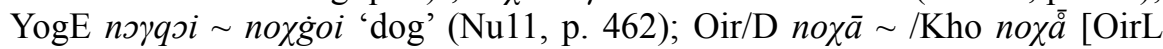

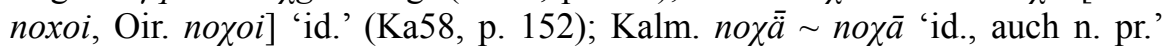
(Ra35, p. 278) - Mo. > Tu. (TMEN id.); (ethnic designation): Trkm. nogay 'Nogai', n. dili 'Nogai language' (BaKaXa68, p. 475); Kzx. noyay 'Tartar' (Shn66, p. 150); Özb. noyåy 'Tatar, Noghay' (CAHG p. 190); Uyy. noyay '(i) Nogai, a Turkic nationality in the USSR; (ii) (his., n.) old name for Tatar' (Sch92, p. 939) • Mo. > Tung. (Castrén 1856, p. 135 [Ewk. ńökâ 'Zobel'(?)]) - 


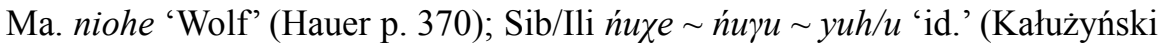
1977, p. 234, Menges 1971, p. 45).

(XI) Mgh. nudut 'eye [correct: (pl.) 'eyes']' $\cdot \mathrm{Mgh} / \mathrm{Le}$ nuddun $\sim / \mathrm{Me}, \mathrm{KI}, \mathrm{LM}$ nudun

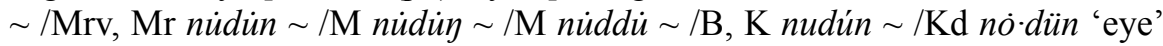
(DoHe93, p. 59; Li54, p. 139; Ra05, p. 35; W71, p. 166 17 ; W72a, p. 174), $\mathrm{Mgh} / \mathrm{Zi}$, Kun nùdün $/ \mathrm{L}_{1,4}$ nudūn $\sim / \mathrm{L}_{2}$ nüdūn 'Auge; $\left(\mathrm{L}_{4}\right)$ Blick, Hoffnungsblick, Hoffnung', (pl.) $/ \mathrm{L}_{2} n \bar{u} d \bar{u} d, \rightarrow / \mathrm{L}_{2}$ (dimin.) nüdūkan $\rightarrow / \mathrm{L}_{2}$ (dimin. pl.) nüdūkat (Iwa61, p. 121; W75a, p. 148; W77, p. 166; W83, p. 573) - Li62, p. 57; Li65, p. 275; MYYC p. 520; Nu11, p. 459; Ry06, pp. 622-623 • MMoS/U/A nidü/n [Cag. MTu. köz] 'Auge'; A nidün qālqa [Osm. göz qapaii] 'Augenlid', (Tu. pl. s.) A nidünlär (Rybatzki, forthcoming b); EMoL nidü/n 'eye' (Ka09, p. 193); MoL nidü/n, KhalL nüd 'eye; anything resembling the eye in shape; meshes of a net, etc.' (Le60, p. 578); Ord. nüdü/n 'œil' (Mos41, p. 503); YogE nüdün nudun /Qinglong nödön 'id.' (Nu11, p. 459); $\mathrm{Oir} / \mathrm{D} / \mathrm{Dz} / \mathrm{Kho} / \mathrm{U}$ nüddün /M nid [OirL nidü/n] 'œil, yeux' (Ka58, p. 152); Kalm/SiddhiKür $\chi$ ar nüden 'BBlack Eye); Möndülguu's younger sister' (Dzagdsüren-Tsolo 1982, p. 312), Kalm. nüdn 'Auge’ (Ra35, p. 282) • Mo. > Tu. Yak. (Kałużyński 1961, p. 44).

(XV) Mgh. pai-i qol 'finger nail' · Haz. pā̄ 'Fuß' - cf. pai in the Pe. part of the vocabulary $+(\uparrow)$ qol; (lit.) 'hand of the foot'! But in Özb. and some Trki sources $q o l$ has also the meaning 'finger', thus 'finger of the food'? But still it is not yet 'finger nail'! Also considered by Weiers (e-mail 9.11.2013), especially what concerns the second part $q o l$, as for the moment problematic and unclear.

(XVI) Mgh. saqal 'beard' - Mgh/Le, Me saghal /Mrv, Mr, M, KI, LM sayal /D, KM, K saǵál (Li54, p. 140; Ra05, p. 37; W71, p. 16620; W72a, p. 179), Mgh/Zi sayal /Kun $s^{a} \gamma^{a} l \sim / \mathrm{L}_{1}$ sagal 'beard' (Iwa61, p. 130; W75a, p. 156), Mgh/Bdx. saqal [Pe. rīs] 'id.' (HeHiThe79, p. 198 41 ); Özb/Afgh. saqal 'id.' (Ja38, p. 221;

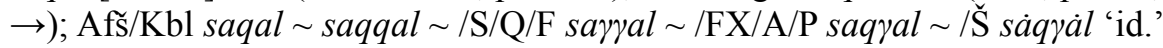
(DoHe89, p. 42) - Li62, p. 62; Li65, p. 276; MYYC 595; Nu11, p. 481; Ry06, pp. 677-678; Rybatzki 2009, pp. 152-153; Rybatzki, forthcoming 2017; VEWT p. $396 \bullet$ Uig. (VIIIff) saqal obviously cognate with saqaq, and probably a dev. n. from *saqa- in the sense of 'something hanging down', 'beard'. S.i.a.m.l.g. (C72, pp. 808-809) - Tr. sakal 'beard, whiskers' $\rightarrow$ sakalsız 'beardless, lack-

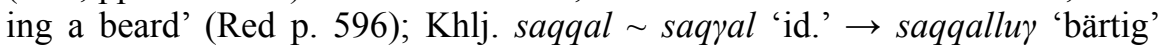
(DoTe80, p. 184); Trkm. sakgal 'id.' $\rightarrow$ sakgalli 'with a beard, bearded', $\rightarrow$ sakgalsïz 'without a beard, beardless' (BaKaXa68, p. 558); Kzx. saqal 'id.' $\rightarrow$ saqaldi 'beard, bearded man; grown up, elderly man' (Shn66, p. 171); Kir. sakal 'id.' $\rightarrow$ sakalduu 'bearded; elderly man; a man of respected/venerable age' (Ju p. 124); Özb. såqål 'beard' $\rightarrow$ såqålli 'bearded', $\rightarrow$ såqålsiz 'beardless', $\rightarrow$ såqåltaråq 'a comb for the beard' (CAHG p. 294; Bor59, p. 380), sersåqål 'having a large beard' (CAHG p. 273; Bor59, p. 364); Trki saqal saq'al 'beard, hair of beard; the fibres which are at the top of the maize husk', ala s.

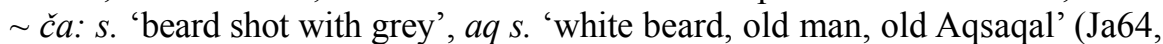

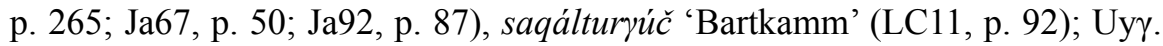


saqal 'beard' $\rightarrow$ saqalsiz 'beardless', $\rightarrow$ saqalliq 'bearded' (Sch92, p. 459); Trki/Ili saqal 'id.' (Ha91, p. 48); Lop. saqal 'id.' (Ma156, p. 158); Sal/Ili sayal 'id.', xaluy s. 'big beard', s. yoxyan kiš 'adult man without a beard' (Ya02, p. 155), saxal 'id.' (Kak62, p. 189), sayat 'sideburns, beard' (Ten76b, p. 470); YogW saqal 'beard, moustache', aq s. 'white-bearded (elder people)' $\rightarrow a q$ saqallï aq attïy ošqa kep-tro 'a white-bearded old man came on a white horse [приехал белобородый старик на белой лошады]', $\rightarrow$ saqaltïq 'rope under the chin (to keep the cap on the head while riding in high winds) [веревочка под подбородком (для удержания на голове шапки при езде при сильном ветре)]' (Mal57, p. 98), *saqat' $\rightarrow$ saqal'tyq 'ribbon under the chin, holding the hat [лента на подбородке, удерживающая шляпу]' (Ten76a, p. 205), saqal 'id.', miča s. 'moustache, beard', cf. $k^{h} i \dddot{c}^{h} i \gamma$ s. 'goatee', pezik s. 'beard' peziik ${ }^{h}$ s. 'whiskers, full beard' (Ro00, p. 357) • Tu. > Mo. - MMoM/S/A saqal [Cag. MTu. saqal] 'id.' (Rybatzki, forthcoming b); MoL saqal, KhalL saxal

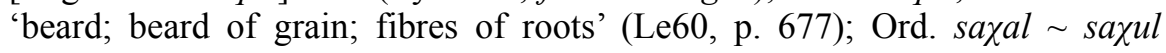
'barbe, moustache, fibrilles (de racine), barbes (d'épi)' (Mos41, p. 553); YogE sagal 'beard' (Nu11, p. 481); Oir/D/Dz/U sazal [OirL saxal] 'barbe, moustache', /D dērk' s. 'moustache', /D örgüne s. 'postiche' (Ka58, p. 155); Kalm. saxel 'Bart (an Menschen, Tieren und Gewächsen)' (Ra35, p. 308) • (Early) Mo. > (Ma. >) Tung. (MT §300; Rozycki 1994, p. 173) - Ma. salu 'Kinnbart' (Hauer p. 400).

(XXI) Mgh. sauk 'cold' - Mgh/Bdx. sou uy yax [Pe. sard, honak] 'kalt; kühl, kalt', sou uy šamal 'Gegend mit kaltem Klima' [tr. Pe. sard-sìr 'Sommerweide' (HeHiThe79, pp. 217 $520,522,205_{214}$ ) vs. Haz. sard, Mgh. zunúg (W75b, p. 101)]; Özb/Afgh. savuq 'cold', s. je- 'to feel cold' (Ja38, p. 222; $\rightarrow$ ); Af̌s/Kbl/A/F/FX/HA/P/Q/SA/Šs soxïx /S soxïy 'id.' (DoHe89, p. 43) - VEWT p. 425 • Uig. (VIIIff) soyïq dev. n. fr. soyi-; 'cold'. S.i.a.m.l.g. (C72, p. 808) Tr. soğuk 'cold (as opposed to hot); cold weather, the cold; cold, frosty, unfriendly; (sexually) frigid' (Red p. 630); Khlj. sovuq $\sim$ sovuq $\sim$ sowuq 'kalt, Kälte' (DoTe80, p. 191) Trkm. sowuk '(n., adj.) cold, chilly; (adj.) surly, unfriendly, cool, cold' (BaKaXa68, p. 582); Kzx. suwiq [суык] 'cold; (fig.) stern' $\rightarrow$ suwïqtau [суықтау] 'chilly' (Shn66, p. 179); Kir. suuk '(n., adj.) cold; frost; cold, cool, unfriendly, surly' $\rightarrow$ suuktuk 'coldness, (n.) cold)' (Ju p. 168); Özb/Buch. souk 'cold, frosty; cold, frosts', s. jēe- s. tij- 'to catch cold' (O05, p. 49), /Urg. so(w)ūq 'cold', hawa sowūq ädi 'the weather was cold' (Dob74, p. 95), Özb. såvuq 'cold, chilly, chilling; loss of vitality from eating', qåra s. 'dry, clear cold weather', s. uruš 'the Cold War', $\rightarrow$ såvuqčilik 'cold relations', $\rightarrow$ såvuqlik 'cold, coldness, coolness; foods low in calories (thin soups, milk, green tea, fruits and vegetables, etc.)', $\rightarrow$ såvuqqån/li 'cool-headed; cold, indifferent', $\rightarrow$ såvuqqånlik 'cool-headedness; cold, indifference', $\rightarrow$ såvuqxåna 'glacier; tepidarium (cooling room in a bath); refrigerator; special cold room in a dungeon' (CAHG p. 295; Bor59, p. 375); Trki sōq sōjúq

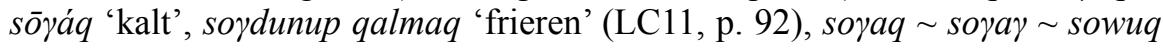
$\sim$ souq $\sim$ sawuq $\sim$ suwaq 'cold, cool; a cold, shivering', soyaq bolap qal- 'to 
become cold', suwaq yel 'syphilis', soyaq teg- 'to catch a cold', soyaqrae ton-

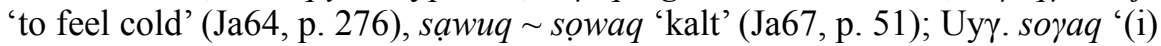
cold; (ii) cold, frosty, indifferent' $\rightarrow$ soyaqčan (med.) 'having a cold', $\rightarrow$ soraqčiliq 'animosity, ill will, grudge, enmity', $\rightarrow$ soraqqan 'calm, cool, indifferent' $\rightarrow$ soyaqqanliq 'coldblooded (animal); cool or calm disposition', $\rightarrow$ soyaqliq 'n. of soyaq; cooling agent for fever' (Sch92, p. 482); Lop. suraq '(n.)

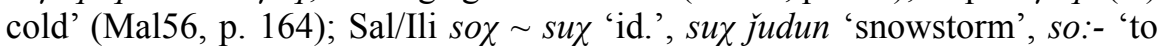
cool, chill', neme so:ji 'the food became cold' (Ya02, pp. 160, 161, 162), /Qh

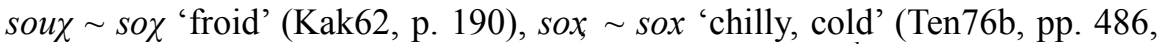
487); YogW Ø, here e.g. seryin 'shade, cool', < Mo. or $t^{h}$ 'ot 'cold' (Ro00, pp. 359,383 ) are used.

(XXV) Mgh. sutu 'milk' - Mgh/Le sùn /Le sunu /Me; LM sun /Mrv, Mr, M sün $/ \mathrm{N}, \mathrm{S}$ su/n $\sim / \mathrm{Kd}, \mathrm{KSn}$ sün $\approx / \mathrm{Z}_{\mathrm{O}}$ üssu 'milk' $\rightarrow \mathrm{Mgh} / \mathrm{Mrv}$ sůntů 'mit Milch' (DoHe93, p. 59; Li54, p. 141; Ra05, p. 39; W71, p. 17493; W72a, p. 180; W72b, p. 5778), Mgh/Zi, Kun sün 'milk' / $\mathrm{L}_{1}$ sün 'Milch; Brustmilch (von Mensch und Tier)', $/ \mathrm{L}_{1}$ sūn ìdahčč 'Säugling' (Iwa61, p. 133; W75a, p.

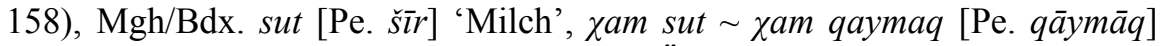
'Sahne, Rahm' (HeHiThe79, p. 210 $360-361$ ); Özb/Afgh. sut $\sim$ su.t 'milk' (Ja38, p. 224; $\rightarrow$ ); Afš//Kbl sit /A sìt süt 'id.' (DoHe89, p. 29; Li57, p. 125) - Joki 1952, p. 277; Li62, p. 65; MYYC p. 614; Nu11, p. 507; Rybatzki, forthcoming 2017; VEWT p. 438 [MTu. sü̈d 'Milch', Trkm. süjt, Yak. üt, Osm. süd, Otü. etc. süt, Kzx. söt, Bšk. höt, Cuv. sat söt 'id.'] • (i) Uig (VIIIff) süt (-d) 'milk'. C.i.a.p.a.l.; in SW Osm. süt, before vowels süd-; Trkm. süyt, süyd(C72, p. 798) - Tr. süt 'milk; latex; milky juice (of some plants); (slang) gasoline, juice' (Red p. 648); Trkm. süyt [сүйт] 'milk; milky, lactic, dairy' (BaKaXa80, p. 597); Kzx. süt 'id.', s. ana 'wet-nurse' $\rightarrow$ (adj.) sütti 'milk, milky, milch, producing much milk' (Shn66, p. 186); Kir. 'süt 'id.' $\rightarrow$ süttüü 'id.' (Ju p. 175); Özb/Buch. süt sūt 'id.' (O05, p. 50), Özb. sut 'id.', $\rightarrow$ sutak '(zool.) nightjar, goatsucker; idiot, buffoon (cf. sotak)', $\rightarrow$ sutči 'milker, milkman or milkmaid' $\rightarrow$ sutčilik 'abstr. of sutči; dairy farming', $\rightarrow$ sutli 'containing milk; milky', $\rightarrow$ sutqon '(bot.) a poisonous species of euphorbia', $\rightarrow$ sutsimon 'milk-like', $\rightarrow$ sutsiz 'milkless' $\rightarrow$ sutsizlik 'lack of milk', $\rightarrow$ sutxor 'milkloving, big milk drinker' $\rightarrow$ sutxorlik 'abstr. of sutxor; enthusiastic drinking of milk' (CAHG p. 300; Bor59, p. 389); Trki süt 'id.' (LC11, p. 92), sùt süt

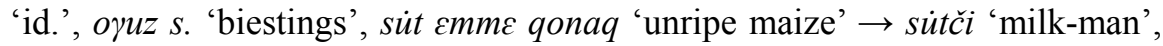

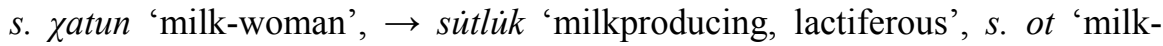
thistle, sow-thistle' (Ja64, p. 282; Ja67, p. 52; Ja89, p. 82), süt 'id.' $\rightarrow$ sütle'to mix with milk, to prepare milk-tea' (Ja89, p. 31), sut 'id.', s. jumraq 'cori-

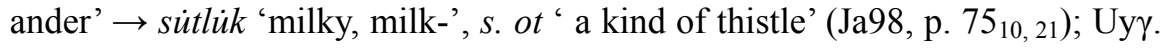
süt 'id.' $\rightarrow$ sütči 'dairyman' $\rightarrow$ sütčilik 'dairy industry', $\rightarrow$ sütlä- 'to admix milk', $\rightarrow$ sütlük 'milk', s. čay 'milk tea' (Sch92, pp. 492-493); Lop. süt 'id.' $\rightarrow$ süttük čă 'milk tea' (Mal56, pp. 165, 187); Sal/Ili sut süt 'id.', súč ča 'milk tea' (Ya02, pp. 162, 163), /Qh sut sut 'id.', sut sayat 'pot au lait' (Kak62, p. 190), süt $\sim$ sü't $\sim$ sü' 'id.', süt'ča 'milk with tea' (Ten76b, p. 490); 
YogW sut süt $\sim$ sot $\sim$ söt 'id.' (Mal57, pp. 104, 106-107; Ten76a, pp. 207208), sut $\sim$ sut $^{h}$ (sutki) 'id.' (Ro00, p. 364) • MMoM sün $\sim$ A sü/n $[$ MTu. Cag. süt] 'Milch; rohe, frische Pferdemilch' - a rare word, attested in MMo. only in the SH (3 times) and the vocabularies in Ar. script (Rybatzki, forthcoming b); EMoL sün 'milk' (Ka09, p. 269); MoL sü/n, KhalL sü̈̈ 'id.' (Le60, p. 744); Ord. 'ُusu 'id.' (Mos41, p. 764); YogE hsun sun ( $\leftarrow$ *üsün) 'id.' (Nu11, p. 507); Oir/D/Dz/Kho/T/U ${ }^{1}$ üs üsün [OirL üsün] 'id.', /Dz üste: cáe 'thé au

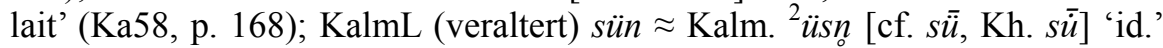
(Ra35, pp. 340, 460) • Recent Mo. > Ma. sun 'milk' (Hauer p. 432, Rozycki 1994, p. 190); Sib/Ili suń 'id.' (Kałużyński 1977, p. 252) • The vocabularies cited reflect two different words. Mackenzie's word could be Tu. because of $t$-, the other occurrences with final $-n$ represent Mo. words. However, Mackenzie's word is morphologically unclear and not transparent; probably not 'with milk', but perhaps the phonological structure with final vowel is influenced by Pšt. šidey šidi šaudo šawdo, šo/udo 'milk' (Rav67, p. 666; Badghisi 1960, p. 166; M27, pp. 72-73; M03, p. 80)?

(XXII) Mgh. tiva 'camel' - Özb/Afgh. tiva 'id.', [in Eastern Turki] tiva tay 'Tiva Tagh' tuya 'camel' (Ja38, pp. 229, 231; $\rightarrow$ ); Mgh/Bdx. tüyä [Pe. šotor] 'id.', mačà $t$. [Pe. ̌̌s.e māde] 'Kamelstute', uonajïn $t$. [Pe. š.-e jawān-e māde] 'junge Kamelstute', barkeš t. $\sim$ tüyä-i barkeš [Pe. šs.e sawārī] 'Reitkamel, (Last-)' (HeHiThe79, p. $201_{103,105,108,109}$ ) vs. Mgh/Z $\mathrm{Z}_{\mathrm{O}}$ timór 'Pferd' (Mo. temegen temēn), cf. also $(\uparrow$ ) under morin (W72b, p. 577 15 ) - Other Mgh. dialects use forms that go back to Mo. temēn $(\rightarrow)$ - Hauenschild 1998, p. 36 [KrimTat. deve 'Kamel', deve qušu 'Strauß'], p. 51 [KrimTat. tüye 'id.']; 2003, pp. 206211; 2006, pp. 126-128; Li65, pp. 281-282; Li66, p. 264; Menges 1935; Rybatzki, forthcoming 2017; Stachowski 1993, p. 214; 1998, p. 226 [Dolg. Yak. taba 'Rentier; Maral']; TMEN §§1015; VEWT p. 468 • Tu. (VIII) tävä (XI) täväy (/Oghuz) däväy 'camel'. There is real doubt about the original form of this word; the oldest recorded form is tävä, but it became an early, first period, 1.-w. in Mo., as [*]temeyen $\sim$ teme $\cdot e n$ which presupposes a final $-y$ [not really, the Mo. form could also go back to *teme $+{ }^{*}$-GAn (VR)]. S.i.a.m.l.g., the NW Bšk., Tat. and SW Az., Gag., Osm., and Trkm. forms all begin with $d^{\circ}$, which was probably the original initial (C72, pp. 447-448) - Tr. deve 'camel' (Red pp. 181-182); Khlj. tävä 'id.' (DoTe80, p. 202); Trkm. düye [дүе] 'id.' (BaKaXa68, p. 289); Kzx. tüye [түйe] 'id.' (Shn66, p. 214); Kir. töö 'id.' (Ju p. 259); Özb. tüa 'id.' (O05, p. 56), Özb. teva (zool./obs.) 'id.' tuya 'id.' $\rightarrow$ tuyači 'camel driver' $\rightarrow$ tuyačilik 'camel-raising', $\rightarrow$ tuyaday $\sim$ tuyadek 'camel-like; huge, gigantic', $\rightarrow$ tuyakaš 'camel driver', $\rightarrow$ tuyapaypoq '(bot.) bindweed, convolvulus', $\rightarrow$ tuyaqush '(zool.) ostrich', $\rightarrow$ tuyasandiq 'large trunk' (CAHG pp. 318, 337; Bor59, pp. 420, 460-461), Özb. > Taj. tuya 'id.'

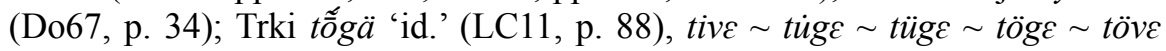
'id.' (Ja64, p. 309), tivä tugä 'id.' (Ja67, p. 56), tive töge tüga tüge 'id.'

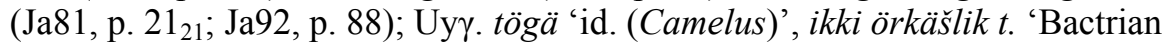
camel (Camelus bactrianus)', nar t. 'dromedary (Camelus dromedarius)' $\rightarrow$ 
tögitapan '(bot.) Zygophyllum oxianum, a kind of bean caper; (med.) flatfoot', $\rightarrow$ tögäči 'camel herder or driver, cameleer' $\rightarrow$ tögičilik 'camel herding or transport', tögiquš '(zool.) ostrich (Struthio camelus)' [Osm. devecilik] (Sch92, pp. 216-217); Trki/Ili tüyä 'id.' $\rightarrow$ tüyäči 'breeder or herder of camels' (Ha91, p. 51); Lop. tögä tögö 'camel' (Mal56, p. 175); Sal/Ili döwce (Ch. döye) 'id.' (Ya02, p. 81), /Qh tüya düya toyi 'id.' (Kak62, p. 193), tövä $\sim$ t'ovä $\sim$ töve $~$

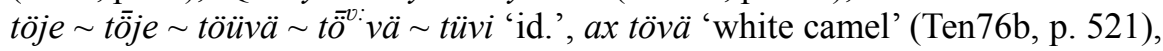
dui 'id.', kijidui 'young camel', qidui 'female camel' (Ma-Ma-Ma 1993, p. 41); YogW $c^{h} i \sim \check{c}^{h} e \sim \check{c}^{h} i y \sim \check{c} e \sim t^{h} i \sim t^{y} i y \sim t i$ 'id.' [Tu.] (Ro00, p. 297) • $\mathrm{MMoM} / \mathrm{S} / \mathrm{A}$ teme $\cdot e / n \sim \mathrm{M} *$ temè $/ n(\rightarrow$ temēcin $) \sim \mathrm{S}$ temē $\sim \mathrm{A}$ temè $/ n$ [MTu., Cag. tevä] U/A temege/ $n$ [MTu. devä] 'camel', (pl.) M teme'et $\sim \mathrm{U}$ temeged $\sim$ A temèt [Cag. tevälär] (Rybatzki, forthcoming b); MoL temege/n, KhalL temee 'camel; bishop (in chess)' (Le60, p. 800); Ord. teme 'chameau; dans quelques expressions le mot teme a le sens de 'grand' (cf. mori, $\dot{u}^{k} \chi e r$ )' (Mos41, p. 656); YogE teme: $n \sim$ temen 'camel' (Nu11, p. 517); OirD/Dz/U teme:n

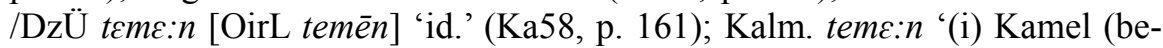
sonders: verschnittene Lastkamele); (ii) Figur im Schachspiel' (Ra35, pp. 390-391); Mgh/Le teman $\sim / \mathrm{Mr}, \mathrm{M}$ temân $\sim / \mathrm{M}$ temâ $\sim / \mathrm{Me}$ tema $[\sim$ urtu kuchutu (lit. 'with a long neck')] / LM tēmān $\sim / \mathrm{B}, \mathrm{N}$ temon $\sim / \mathrm{S}$ tem's 'id.' (Li54, p. 142; W71, p. $167_{28}$; W72a, p. 181), Mgh/L timān 'id.' / $\mathrm{L}_{3}$ Ar. ibil, Trkm. diyah, Mgh. timān, Pšt. uš, Pe. uštur 'id.' (W73, pp. 508 $61: 6,515,516$; W75a, p. 162; $\leftarrow$ ) M Mo. > Tu. > Tung. (Kałużyński 1961, pp.16, 42 [täbiän]; TMEN id.) - Mo. > Ru. (TMEN id.) - Mo. > Tung. (Grube 1900, p. 81; Kałużyński 1971b, p. 46; MT §202; Poppe 1966, p. 191; Rozycki 1994, p. 206; Schmidt 1927, p. 59), 1933, pp. 409, 410 - Jur. temuge 'id.' (Kane 1989, p. $214_{409}$ ), Sib. temaN 'id.' (Yamamoto 1969, p. 1082215), Sib/Ili temen 'zweihöckriges Kamel' (Kałużyński 1977, p. 260), Ma. temen 'id.' (Hauer p. 467) • With regard to the semantics of $\mathrm{Mgh} / \mathrm{Z}_{\mathrm{O}}$, Weiers (W72b.578, under muri) rightly stated that "Bei dem substratartigen Sprachzustand sind solche Verwechselungen leicht möglich, vgl. auch $\left.\mathrm{N}^{\circ} 15\right)$ ”. Mgh. $<$ Tu., cf. e.g. $(\leftarrow)$ Özb/Afgh., Özb., Uyץ.

(VII) Mgh. ukar 'cow' - Mgh/Le ukarr 'a bull' /Mrv ükär 'Ochs, Rindvieh' /Mr, $\mathrm{M}$ ukkar 'boeuf' $\sim / \mathrm{N}, \mathrm{S}$ ukar $\sim$ okar 'Rind, Tier' ? ? / $\mathrm{Z}_{\mathrm{O}}$ buqár 'Kuh' [influenced by Ar. $\rightarrow$ ? (VR)] (Li54, p. 143; Ra05, p. 41; W72a, p. 182; W72b,

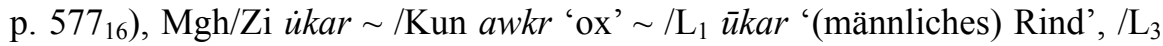
Ar. baqar, Trkm. suqur, Mgh. ükar, Pšt. ġwaya (sic), Pe. gāu 'Rind' (Iwa61, p. 143; W73, pp. 508 $62: 1,515$; W75a, p. 166) vs. Mgh/Bdx. hokkizz [Pe. gūsāle] 'Ochse' (HeHiThe79, p. 201 111 ); Özb/Buch. hokus okus 'id.' (O05, p. 21), /Urg. öküz 'ox' (Dob74, p. 94) - Hauenschild 2003, pp. 170-172; Li59, pp. 266-268; Li62, p. 35; Li65, p. 279; MYYC p. 698; Nu11, p. 367; Pinault 1997, pp. 201-203; Ry06, pp. 79-80; Rybatzki, forthcoming 2017; Stachowski 1993, p. 190 [Dolg. ogus 'eine Stierfigur aus Holz, die der Schamane dem feindlichen Geist schenkt, damit er den Kranken verläßt', *kihiläk ogus [kisiläxx

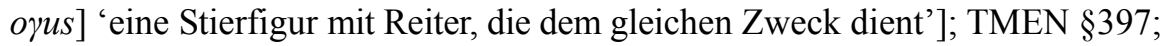


VEWT p. 370 • Common Tu. > MMoA öküz («; Rybatzki, forthcoming b) Tu. (VIIIff) öküz one of the several terms for bovines, best translated 'ox', since it is more specific than $u d$ and sï̈ir but not quite so specific as buqa 'bull'. S.i.m.m.l.g., but usually meaning 'castrated bull, bullock'. Almost certainly borrowed from Tokharian (C72, p. 120) - Bolghar Tu. > Mo. $\mathrm{MMoM} / \mathrm{P} / \mathrm{A}$ hüker $\sim \mathrm{P}$ huker $\sim \mathrm{S}$ üger $\sim \mathrm{S} / \mathrm{P}$ hüger $\sim \mathrm{U} / \mathrm{A}$ üker $[\mathrm{MTu}$. sï̈ïr, Cag. $u y(\leftarrow u d) \sim \ddot{o k} \ddot{u} z]$ 'bovine, cattle; also animal of the 12-animal-cycle', (pl.) U üked, S/P hüker jil U üker jil '2. Jahr des Zyklus' [MTu. Uig. ud yïl], A keheriki hüker 'Antilope (wörtlich Steppenochse)', ArmKir okar (= *üker); Geor. ükür (Rybatzki id.); EMoL üker 'ox, a bovine' (Ka09, p. 315); MoL üker, KhalL üxer 'bovine animal, ox, cow; large, big; the second of the twelve animals of the zodiac' (Le60, p. 1003); Ord. $\dot{u}^{k}$ Xer 'bœuf' (Mos41, p. 754); YogE hgor 'bovine, ox' (Nu11, p. 367); Oir/D ükür /Dz/U ükkür [OirL ükür] 'vache', /D ükrinn nüd 'nom d'un baie', /D/Dz monyol ükür 'bête à cornes à l'exception du yak', /Dz ulān ükkür 'yak' (Ka58, p. 167); Kalm. 'ükr 'Rindvieh; speziell Kuh' (Ra35, p. 456) • Mo. > Tu. (TMEN id.) - Yak. (Kałużyński 1995, pp. 222-223 ['part of plant names'; in other Tu. languages the use of the word as part of plant names is restricted to Cuv. (Hauenschild 1996, pp. 95-96 $\left.13,138_{348}\right)$ ], Yak. > Tung. (Castrén 1856, p. 129; Doerfer 2004, pp. 631, 632; Halén 1978, p. 175; Schmidt 1923, p. 28) • Mo. > Tung. (Kałużyński 1971b, p. 52; MT §156; Poppe 1966, p. 198; 1972, p. 99; TMEN id.).

(V) Mgh. usun 'water' - Mgh/Le ussun /Me, Mrv, Mr, M, Kd; KS, KI, LM usun $/ \mathrm{M}$ usu $\sim / \mathrm{Me}$ oson $\sim / \mathrm{LM}$ su $\sim / \mathrm{N}, \mathrm{S} u s u / n$ 'water' [vs. Haz. äb (W75b, p. 101)], /Me usuni dotanakini 'duck', usuni nureki 'boat', /K usun ki- 'flüssig machen' $\rightarrow$ /Me usutu 'barley (lit. 〈having water)' (DoHe93, p. 60; Li54, p. 144; Ra05, p. 41; W71, pp. 1642,4, 177 $130,178_{143}$; W72a, p. 183), Mgh/Zi usun $\sim /$ Kun awsawn $\sim / \mathrm{L}_{1}$ usūn 'Wasser' $\rightarrow /$ Kun $a^{w} s a^{w} n \gamma r \sim / \mathrm{L}_{1}$ usunġar $\sim / \mathrm{L}_{1}$ usüngar 'Handwaschung; rituelle Waschung vor dem Gebet' (Iwa61, p. 142; W75a, p. 169) vs. Mgh/Bdx. suw [Pe. äb] 'Wasser', suusiz $\sim$ suusayan $[\mathrm{Pe}$. tešne] 'durstig', su yoy [Pe. āb nīst] 'es gibt kein Wasser', bisuu [Pe. bī-āb] 'ohne Wasser' (HeHiThe79, pp. 206 $253,216_{505}, 219_{593}$ ); Özb/Buch. su 'id.' (O05, p. 51), /Qil. su 'id.', s. at 'water-horse' (Jar37, p. 52), /Afgh. su $\sim s u \cdot \sim$ su: 'id.', suvi 'his etc. water' (Jar38, p. 223) - Doerfer 1993, p. 81; Li62, p. 72; Li65, p. 288; MYYC p. 682; Nu11, pp. 535-556; Ry06, pp. 179-181; TMEN §47; VEWT p. 517 [Šor, Koib., Kyz. ustan 'Wasserratte' < Mo. us + $t A n] \cdot \mathrm{MMoM} / \mathrm{S} / \mathrm{P} / \mathrm{U} / \mathrm{A}$ usu/n [MTu. Cag. su] 'Wasser, Gewässer' (Rybatzki, forthcoming b); EMoL usu/n 'water' (Ka09, pp. 301-302); MoL usun, KhalL us 'water; body of water' (Le60, p. 887); Ord. usu 'eau; puits creusé pour en tirer de l'eau; sérosité' (Mos41, p. 744); YogE qusun 'water' (Nu11, pp. 535556); Oir/D us/n $\sim / \mathrm{Kho} / \mathrm{U}$ usun $\sim / \mathrm{Dz}$ ussun [OirL usun] 'id.' (Ka58, p. 167); Kalm. usn 'id.' (Ra35, p. 452) • Mo. > Tu. - YogW (NuRo96, pp. 80-81 355,358 ; Ölmez 1998, p. 168).

(II) Mgh. utufang 'bread' - Mgh/Le ukpang /Me uftang /Mrv üftäy [Tu. (dial.)

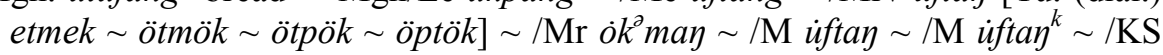


ukmang $\sim / \mathrm{KI}$ ukmäng $\sim / \mathrm{KQ}, \mathrm{SB}$ otpang $\sim / \mathrm{K}, \mathrm{N}, \mathrm{S}$ ukmáy $\sim / \mathrm{N}$ ukméy $/ \mathrm{D}$ uftáy $\sim / \mathrm{Kd}$ hukmaryga $\sim / \mathrm{Z}_{\mathrm{N}}$ utpáy $\sim / \mathrm{Z}_{\mathrm{O}}$ utmang 'bread; $(\mathrm{N})$ Brot, Essen, Speise' (Li54, p. 143; Ra05, p. 41; W71, p. 164 ${ }_{1}$; W72a, p. 182; W72b, pp. 576577), Mgh/Zi ùkmang 'bread, loaf, muffin' $\sim / \mathrm{L}_{1}$ ukmang 'Brot' (Iwa61, p. 278; W75a, p. 166), Mgh/Bdx. nan ekmek [Pe. nān] 'id.' (HeHiThe79, p. $\left.210_{352} ; \rightarrow\right)-$ DoHe93, p. 58 [Mgh. < Tu. hötmäk]; Buell-Anderson 2010, p. 631 'bread'; Joki 1952, pp. 138-139; Li54, p. 143; Li62, p. 61; Li65, p. 278; Li66, p. 190; MYYC p. 154 [cake, flat cake], Nu11, p. 470 [in modern Mo. languages only Dag. Kalm. and languages of Gansu-Qinghai, but not YogE]; VEWT p. 376 [Uig., MTu.; NE, NW (partly) and SW languages, missing in NW (partly), NC, SC and SE languages] - Tu. (XI) ätmäk Uig. (VIIIff) ötmäk the oldest of three similar words for 'bread', the others being äpmäk and $\ddot{a} k m a ̈ k$, noted in $\mathrm{NC}, \mathrm{NW}$, and $\mathrm{SW}$ and prob. a recent secondary form due to the supposed connection with äk-. Ötmäk seems to be the earlier of the two forms. Although - $m A K$ is normally an infinitive s., it is not possible to connect the word semantically with any verb. Survives with initial $\ddot{o}$ - (occasionally $\ddot{u}$-) in some NE languages, and NW KarT, and with initial $\ddot{a}$ - or $i$ - (?e-) in other NE languages, NC, NW, and SW (C72, p. 60) - Tr. ekmek 'bread; food, subsistence; livelyhood, job' (Red p. 214); Khlj. ätmäk $\left(\leftarrow{ }^{*}\right.$ pätmäk $) \sim$ hikmàk 'bread' (Do71, p. 293) hikmäk 'id.', hikmäk qatuqi 'Bouillon', hikmäk yapili 'Bäcker' (DoTe80, p. 132) • Tu. > Mo. - MMoS ütmek 'gerösteter Weizenkuchen' S üdme [k] 'cake' A ötüme [< Tu., cf. Cag. ötme 'Weizenstengel, im Feuer gekocht' (Kúnos 1902, p. 155)] A ötmek [Ar., Pe. nān; MTu. Cag. etmäk] A etmek [Cag. id.] 'bread'; MMo., or MTu. > ArmKir ötmek 'id.' (Rybatzki, forthcoming b); Kalm. ödmag 'id.' [Sol. utuma] (Kempf 2012, p. 147; Ra35, p. 293) • The Mgh. word is structurally not really clear. For 'bread', in the region under discussion, mostly the word nan, cf. Pe. vocabulary under nun, is used.

\section{To be continued}

\section{Abbreviated References, Dialects, Languages and Symbols}

$\mathrm{A} \quad=\mathrm{MMoA}$

abl. ablative

abstr. abstract

acc. accusative

adj. adjective

adv. adverb

Afs̃. $\quad$ Afšār

Af̌̃s/A Afšār from Alī-Qūrčī (Iran), collected by Doerfer-Hesche (DoHe89)

Afš/F Afšār from Fīrūz-ābād (Iran), collected by Doerfer - Hesche (DoHe89)

Afš/FX Afšār from Qal'a-ye Farhād-Xān (Iran), collected by Doerfer - Hesche (DoHe89)

Afš/HA Afšār from Ḥoseyn-ābād-e Sarmašad (Iran), collected by Doerfer-Hesche (DoHe89) 
Af̌̃/Kbl Afs̃ār from Kabul (Afghanistan), collected by Ligeti (Li57) and Doerfer-Hesche (DoHe89)

Afš/P Afšār from Paradomba (Farādonba) (Iran), collected by Doerfer-Hesche (DoHe89)

Af̃̃̌lQ Afs̃ār from Qorwa (Iran), collected by Doerfer-Hesche (DoHe89)

Af̌s/Š $\quad$ Afšār from Šahrak (Iran), collected by Doerfer-Hesche (DoHe89)

Af̌̃/S Afs̃ār from Sonqor (Iran), collected by Doerfer-Hesche (DoHe89)

Afš/SA Afšār from Qal'a-ye Soleymān-ābād (Iran), collected by Doerfer-Hesche (DoHe89)

Alt. Altai (South Siberian Turkic language)

Anat. Anatolian dialects of Turkish

Ar. Arabic

Ar/Buch. Arabic spoken in Buchara

ArmKir Middle Mongyol in Armenian script (Li65)

As85 Aslanov, M. G. (1985) [1966]: Puštu-russkil slovarb. Moskva.

Av. Avestian

Az. $\quad$ Azeri

BaKaXa68 Baskakov, N. A. - Karryev, B. A. - Xamzaev, M. Ja. (1968): Turkmensko-russkiŭ slovarb. Moskva.

Bao. Baoan

Bor59 Borovkov, A. K. (1959): Uzbeksko-russkiľ slovarb. Moskva.

bot. botany, botanical

Bšk. Baškir

Cag. Cagatai

CAHG The Central Asian Heritage Group (2006): Uzbek-English Dictionary. Samarkand.

caus. causative

CC Codex Cumanicus

cf. compare

Ch. Chinese

Chor(Tu.) Choresmian (Turkic)

c.i.a.m.l.g. common in all main language groups

c.i.a.p.a.l. common in all periods and languages

coll. colloquial

Cuv. Chuvash

C72 Clauson, Sir G. (1972): An Etymological Dictionary of Pre-thirteenth-century Turkish. Oxford.

den. denominal

dev. deverbal

Dgx. Dongxiang (Santa)

dial. dialect, dialectal/ly

Dob74 Dobos, É. (1974): An Oghuz Dialect of Uzbek Spoken in Urgench. AOH Vol. 28, pp. $75-97$.

DoHe89 Doerfer, G.-Hesche, W. (1989): Südoghusische Materialien aus Afghanistan und Iran. Wiesbaden.

DoHe93 Doerfer, G.-Hesche, W. (1993): Zwei moyoli Texte. Festschrift für Raija Bartens. Helsinki, pp. 53-60 (Mémoires de la Société Finno-ougrienne 215).

Dolg. Dolgan 
DoTe80 Doerfer, G. - Tezcan, S. (1980): Wörterbuch des Chaladsch (Dialekt von Charrab). Budapest (Bibliotheca Orientalis Hungarica 26).

Do67 Doerfer, G. (1967): Türkische Elemente im Tadschikischen. Wiesbaden (Abhandlungen für die Kunde des Morgenlandes XXXVII/3).

Do69 Doerfer, G. (1969): Die özbekischen Lehnwörter in der Sprache der Araber von Buchara. Central Asiatic Journal Vol. 12, pp. 296-308.

Do71 Doerfer, G. (1971): Khalaj Materials. Bloomington (Indiana University Uralic and Altaic Series 115).

Du73 Dulling, G. K. (1973): The Hazaragi Dialect of Afghan Persian. London (Central Asian Monographs 1).

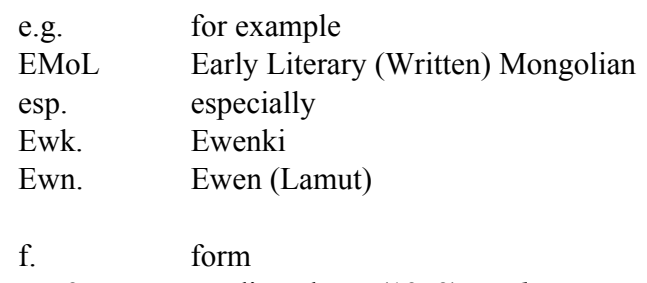

Fe59 Ferdinand, K. (1959) Preliminary Notes on the Hazāra Culture (The Danish Scientific Mission to Afghanistan 1953-55). København (Historisk-filosofiske meddelelser udgivet af Det Kongelige Danske Videnskabernes Selskab 37/5).

fig. figurative

folk. folkloristic

fr. from

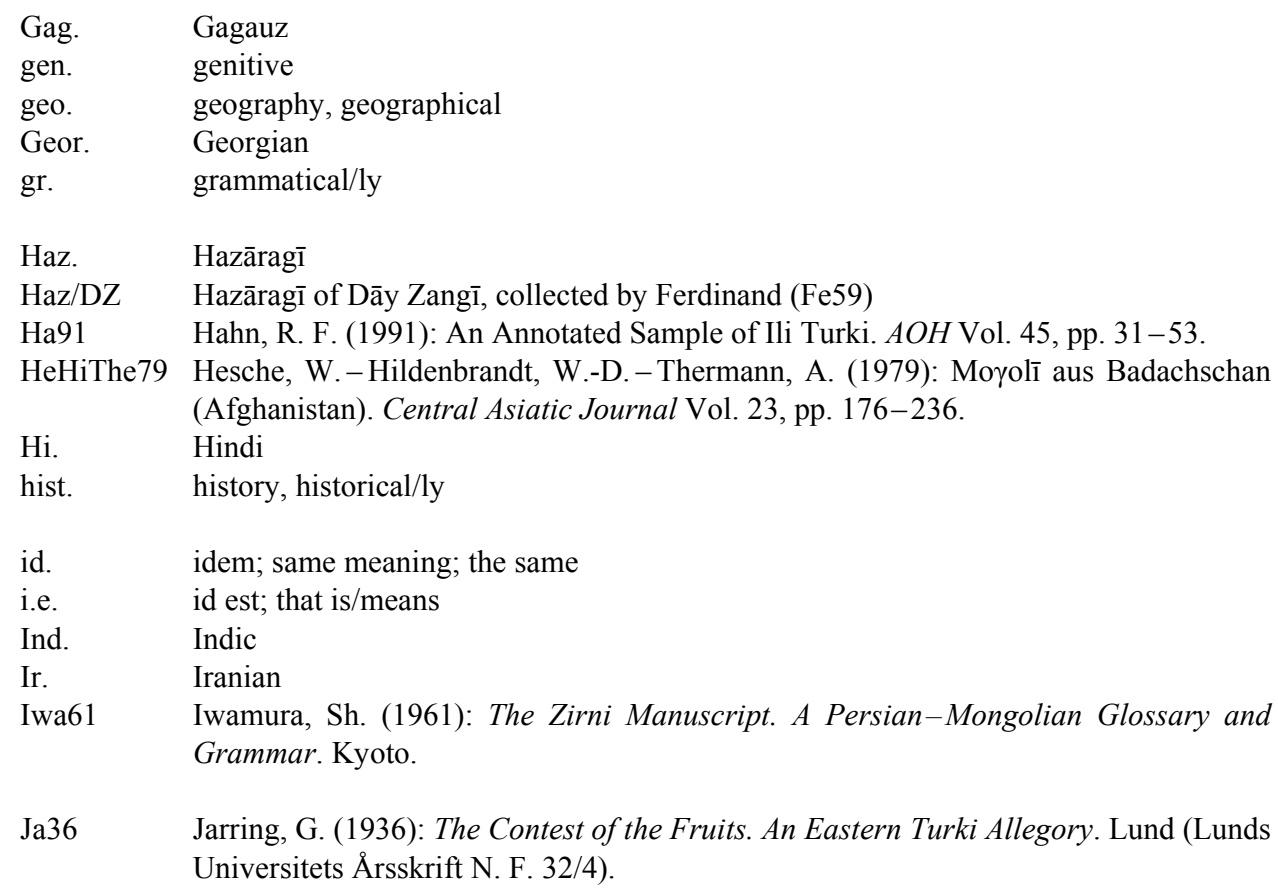


Ja37 Jarring, G. (1937): The Uzbek Dialect of Qilich (Russian Turkestan) with Texts and Glossar. Lund-Leipzig (Lunds Universitets Årsskrift N. F. 33/3).

Ja38 Jarring, G. (1938): Uzbek Texts from Afghan Turkestan with Glossary. Lund-Leipzig (Lunds Universitets Årsskrift N. F. 34/2).

Ja64 Jarring, G. (1964): An Eastern Turki-English Dialect Dictionary. Lund (Lunds Universitets Årsskrift, N.F. 56/4).

Ja67 Jarring, G. (1967): Wörterverzeichnis zu G. Raquettes Ausgabe von Täji bilä Zohra. Lund (Acta Universitatis Lundensis. Sectio I Theologica juridica humaniora 4).

Ja80 Jarring, G. (1980): Literary Texts from Kashghar. Lund (Acta. Skriver utgivna av Kungl. Humanistiska Vetenskapssamfundet i Lund LXXIV).

Ja81 Jarring, G. (1981): Some Notes on the Eastern Turki (New Uighur) Munazara Literature. Lund (Scripta minora. Studier utgivna av Kungl. Humanistiska Vetenskapssamfundet i Lund 1980-1981/2).

Ja87 Jarring, G. (1987): Dervish and Qalandar. Lund (Scripta minora. Studier utgivna av Kungl. Humanistiska Vetenskapssamfundet i Lund 1985-1986/2).

Ja92 Jarring, G. (1992): Garments from Top to Toe. Lund (Scripta minora. Studier utgivna av Kungl. Humanistiska Vetenskapssamfundet i Lund 1991-1992/2).

Ja96 Jarring, G. (1996): The Moen Collection of Eastern Turki (Modern Uighur) Popular Poetry. Lund (Scripta minora. Studier utgivna av Kungl. Humanistiska Vetenskapssamfundet i Lund 1996-1997/1).

Ja98 Jarring, G. (1998): Agriculture and Horticulture in Central Asia in the Early Years of the Twentieth Century. With an Excursus on Fishing. Lund (Scripta minora. Studier utgivna av Kungl. Humanistiska Vetenskapssamfundet i Lund 1997-1998/2).

Ju Judaxin, K. K. (1965): Kirgizsko-russkil slovarb. Moskva.

Jur. Jurchen

Kak62 Kakuk, Sz. (1962): Un vocabulaire salar. AOH Vol. 14, pp. 173-196.

Kal. Kalasha

Kalm. Kalmuck

KalmL Literary Kalmuck

KarT Karaim spoken in Troki (Trakai)

Kaš. Mạ̣mūd al-Kāšyarī

Kaz. Kazan-Tatar

Ka09 Kara, Gy. (2009): (with the assistance of Marta Kiripolská) Dictionary of Sonom Gara's Erdeni-yin Sang. A Middle Mongol Version of the Tibetan Sa skya Legs bshad. Mongol-English-Tibetan. Leiden-Boston (Brill's Inner Asian Library 23).

Ka58 Kara, Gy. (1958): Notes sur les dialectes oirat de la Mongolie Occidentale. $A O H$ Vol. 8, pp. $111-168$.

Kh. Spoken Khalkha

KhalL Literary Khalkha

Khit. Khitan

Khlj. Khalaj

Khot. Khotanese

Khow. Khowar

KiMi78 Kiseleva, L. N. - Mikolaǐčik, V. I. (1978): Dari-russkil̆ slovarb. Moskva.

Kir. Kirghiz

Kkp. Karakalpak

Koib. Koibal 


$\begin{array}{ll}\text { KrimTat. } & \text { Krim-Tatar } \\ \text { Kum. } & \text { Kumück } \\ \text { Kurd. } & \text { Kurdish } \\ \text { Kyz. } & \text { Kyzyl } \\ \text { Kzx. } & \text { Kazax }\end{array}$

Lat. Latin

LC11 Le Coq, A. v. (1911): Sprichwörter und Lieder aus der Gegend von Turfan. LeipzigBerlin (Baessler Archiv, Beiheft 1).

LC18/19 Le Coq, A. (1918-1919): Osttürkische Gedichte und Erzählungen. I. Die Texte des Mullā Yüz-bäschī aus Kutschā. II. Erzählung des in Kutscha ansässigen Qomulluq Seifullāh Achond. III. Erzählungen des Üsüp Achond, des Sohnes des Mir-ab von Qara-Chōdscha, Mämäsīt Tochoi. Keleti Szemle Vol. XVIII, pp. 50-118.

LC22 Le Coq, A. v. (1922): Eine Liste osttürkischer Pflanzennamen. Baessler Archiv Vol. VI, pp. $118-129$.

Le60 Lessing, F. D. (1960): Mongolian-English Dictionary. Bloomington.

lit. literary

Li54 Ligeti, L. (1954): Le lexique moghol de R. Leech. AOH Vol. 4, pp. 119-157.

Li57 Ligeti, L. (1957): Sur la langue des Afchars d'Afghanistan. $A O H$ Vol. 7, pp. 109156.

Li58 Ligeti, L. (1958): Deux tablettes de T'ai-tsong des Tsing. $A O H$ Vol. 8, pp. 201-240.

Li59 Ligeti, L. (1959): Les mots solons dans un ouvrage chinois des Ts'ing. $A O H$ Vol. 9, pp. $231-272$.

Li62 Ligeti, L. (1962): Un vocabulaire mongol d'Istanbul. $A O H$ Vol. 14, pp. 3-99.

Li64 Ligeti, L. (1964): Les voyelles longues en Moghol. AOH Vol. 17, pp. 1-48.

Li65 Ligeti, L. (1965): Le lexique mongol de Kirakos de Gandzak. AOH Vol. 18, pp. $241-$ 297.

Li66 Ligeti, L. (1966): Un vocabulaire sino-ouighour des Ming. Le Kao-tsch'ang-kouan yichou du Bureau des Traducteurs I-II. AOH Vol. 19, pp. 117-201, 257-316.

Li70 Ligeti, L. (1970): Le tabghatch, un dialect de la langue sien-pi. In: Ligeti, L. (ed.): Mongolian Studies. Budapest (Bibliotheca Orientalis Hungarica 14), pp. 265-308.

Lop. Lopnor (Lobnor)

loc. locative

1.-w.(s) loan-word(s)

$\mathrm{M} \quad=\mathrm{MMoM}$

Ma. Manchu

MA Poppe, N. N. (1938): Mongolbskiŭ slovarb Mukaddimat al-Adab. Moskva-Leningrad.

Mal56 Malov, S. E. (1956): Lobnorskil jazyk. Frunze.

Mal57 Malov, S. E. (1957): Jazyk želtyx ŭgurov. Alma-Ata.

med. medical

metaph. metaphorical

Me55 Menges, K. H. (1955): Glossar zu den volkskundlichen Texten aus Ost-Türkistan II. Wiesbaden (Akademie der Wissenschaften und der Literatur, Mainz. Abhandlungen der Geistes- und Sialwissenschaftlichen Klasse, Jahrgang 1954, Nr. 14).

Mgh. Mơolī

$\mathrm{Mgh} / \mathrm{B} \quad$ Moyolī from Bedawi collected by Weiers (W71, W72a)

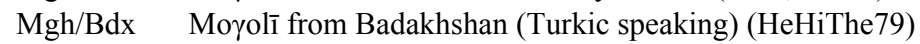


Mgh/D Mojolī from Du Rudi collected by Weiers (W71, W72a)

$\mathrm{Mgh} / \mathrm{DS} \quad$ Moyolī from Deh Šeikh collected by Weiers (W71, W72a)

$\mathrm{Mgh} / \mathrm{K} \quad$ Moyolī from Kundur collected by Weiers (W71, W72a)

$\mathrm{Mgh} / \mathrm{Kd} \quad$ Moyolī from Kundur, published by Doerfer-Hesche (DoHe93)

Mgh/KI Moyolī from Kundur, published by Iwamura - Schurmann (1954), quoted after W71

$\mathrm{Mgh} / \mathrm{KM} \quad$ Moyolī from Kariz Mulla collected by Weiers (W71, W72a)

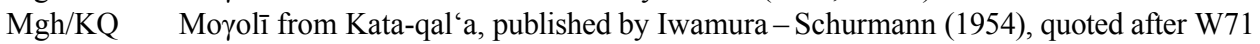

Mgh/KS Mơolī from Kārēz-i-Mullā, published by Iwamura-Schurmann (1954), quoted after W71

Mgh/KSn Moyolī from Kārēz-i Sultạn (province Herāt), published by Doerfer-Hesche (DoHe93)

Mgh/Kun Literary Moyolī (Qundahar manuscript) according to Iwa61

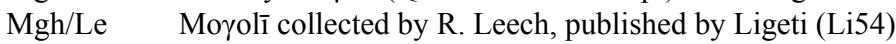

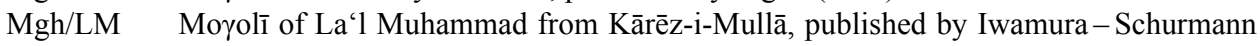
(1954), quoted after W71

$\mathrm{Mgh} / \mathrm{L}_{1} \quad$ Literary Moyoli according to W75a

$\mathrm{Mgh} / \mathrm{L}_{2} \quad$ Literary Moyolī according to W77

$\mathrm{Mgh} / \mathrm{L}_{3} \quad$ Literary Moyolī according to W73

$\mathrm{Mgh} / \mathrm{L}_{4} \quad$ Literary Moyolī according to W83

$\mathrm{Mgh} / \mathrm{M} \quad$ Mangut dialect of Moyolī, collected by Ligeti (Li54)

$\mathrm{Mgh} / \mathrm{Me} \quad$ Mojolī vocabulary of W. H. Merk (W71)

$\mathrm{Mgh} / \mathrm{Mr} \quad$ Marda dialect of Moyolī, collected by Ligeti (Li54)

$\mathrm{Mgh} / \mathrm{Mrv} \quad$ Moyolī collected by Ramstedt in Merv (Ra05)

Mgh/MS Marda dialect of Moyolī, collected by Ligeti (Li54)

$\mathrm{Mgh} / \mathrm{N} \quad$ Mojolī from Nau collected by Weiers (W71, W72a)

$\mathrm{Mgh} / \mathrm{S} \quad$ Moyolī from Samanabad collected by Weiers (W71, W72a)

Mgh/SB Mojolī from Bāylān, published by Iwamura-Schurmann (1954), quoted after W71

$\mathrm{Mgh} / \mathrm{Z} \quad$ Mangut dialect of Morolī, collected by Ligeti (Li54)

$\mathrm{Mgh} / \mathrm{Zi} \quad$ Literary Moyolī (Zirni manuscript) according to Iwa61

$\mathrm{Mgh} / \mathrm{Z}_{\mathrm{N}} \quad$ Moyolī wordlist collected by Weiers in Zirni (W72b)

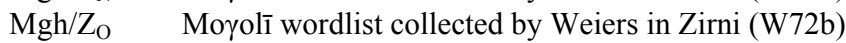

MghL Literary Moyolī

Mgr. $\quad$ Mongour

MIr. Middle Iranian

Mir06 Mirboboev, A. (2006): Tadžiksko-russkiľ slovarb. Dušanbe.

Mj. Munja

MMoA Middle Mongrol written in Arabic script

MMoM Middle Mongrol from the "Secret History of the Mongols"

MMoP Middle Mongyol written in hPags-pa script

MMoS Middle Mongrol written with Chinese characters

$\mathrm{MMoU} \quad$ Middle Mongyol written in Uigur script

Mo. Mongolic

MoL Literary (Written) Mongol

Mos41 Mostaert, A. (1941-1942): Dictionnaire Ordos. Peking.

MPeM Manichean Middle Persian

MT Doerfer, G. (1985): Mongolo-Tungusica. Wiesbaden (Tungusica 3).

MTu. $\quad$ Middle Turkic

MYYC Zhu Sun et alii (1990): Menggu yuzu yuyan cidian. Xining.

M03 Morgenstierne, G. (2003): A New Etymological Vocabulary of Pashto. Wiesbaden. 
Morgenstierne, G. (1927): An Etymological Vocabulary of Pashto. Oslo (Skrifter utgitt av Det Norske Videnskaps-Akademi i Oslo, Hist.-Filos. Klasse 1927, No. 3).

M28 Morgenstierne, G. (1928): Notes on Shughni. Norsk tidsskrift for sprogvidenskap Vol. 1, pp. 32-84.

M29 Morgenstierne, G. (1929): Indo-Iranian Frontier Languages I: Parachi and Ormuri. (Instituttet for sammenlignende kulturforskning) Oslo.

M38 Morgenstierne, G. (1938): Indo-Iranian Frontier Languages, II: Yidgha-Munji, Sanglechi-Ishkashmi and Wakhi. (Instituttet for sammenlignende kulturforskning) Oslo.

M74 Morgenstierne, G. (1974): Etymological Vocabulary of the Shugni Group. Wiesbaden.

n. noun, note, name

NC North-Central

NE North-East

n.o.a.b. noted only as below

n. pr. (m./f.) personal name (masculine/femine)

NuRo96 Nugteren, H.-Roos, M. (1996): Common Vocabulary of the Western and Eastern Yugur Languages. The Turkic and Mongolic Loanwords. AOH Vol. 49, pp. 25-91.

Nu11 Nugteren, H. (2011): Mongolic Phonology and the Qinghai-Gansu Languages. Utrecht.

NW North-West

obs. obsolete

Oir/D Oirat/Dörböt (Ulāngom)

Oir/Dz Oirat/Dzakhačin (Kobdo)

Oir/DzM Oirat/Dzakhačin (Mankhan sumun)

Oir/DzÜ Oirat/Dzakhačin (Üyenč sumun)

Oir/Kho Oirat/Khoton (Ulāngom)

Oir/M Oirat/Mingat (Kobdo)

Oir/T Oirat/Torghut (Kobdo)

Oir/U Oirat/Uriankhaĭ (Bayan-Ölgǐ̄)

OirL Literary Oirat

Ord. Ordos

Orm. Ormuri from the Logar Valley south of Kabul

Orm/Kan Ormuri from Kaniguram in Waziristan

Orš. Orošori

Osm. Ottoman Turkish

Otü. $\quad$ Eastern Türki (= Trki Uy $\quad$.)

Özb. (Literary) Özbek

Özb/Afgh. Özbek from Afghanistan

Özb/Buch. Özbek from Buchara

Özb/Qil. Özbek from Qilich

Özb/Urg. Oghuz dialect of Özbek from Urgench

O05 Olufsen, O. (1905): The Second Danish Pamir Expedition: A Vocabulary of the Dialect of Bokhara. København.

$\mathrm{P}=\mathrm{MMoP}$

Pahl. Pahlavi

Par. Parachi

Pa75 Paxalina, T. N. (1975): Vaxanskiü jazyk. Moskva. 
$\begin{array}{ll}\text { Pe. } & \text { Persian } \\ \text { phys. } & \text { physical } \\ \text { pl. } & \text { plural } \\ \text { Pl } & \text { Platts, J. T. }\left(1884,1988^{2}\right): \text { A Dictionary of Urdu, Classical Hindi, and English. Lon- } \\ & \text { don. } \\ \text { prob. } & \text { probably } \\ \text { prov. } & \text { provincial } \\ \text { PrthM } & \text { Manichean Parthian } \\ \text { Pšt. } & \text { Pašto } \\ \text { Pšt/Dial. } & \text { Dialect/s of Pašto } \\ \text { Pšt/Waz } & \text { Pašto of Waziristan }\end{array}$

Ras Golden, P. B. (2000): The King's Dictionary: The Rasülid Hexaglot. Fourteenth Century Vocabularies in Arabic, Persian, Turkic, Greek, Armenian and Mongol. LeidenBoston (Handbuch der Orientalistik 8, Abt. Zentralasien, 4. Bd.).

Rav67 Raverty, H. G. (1867): A Dictionary of the Puk'hto, Pus'hto, or Language of the Afghans: With Remarks on the Originality of the Language, and its Affinity to other Oriental Tongues. Second edition, with considerable additions. London.

Ra05 Ramstedt, G. J. (1905): Mogholica - Beiträge zur Kenntnis der Moghol-Sprache in Afganistan. Helsingfors (JSFOu Vol. XXIII, No. 4).

Ra35 Ramstedt, G. J. (1935): Kalmückisches Wörterbuch. (Lexica Societatis Fenno-Ugricae III.) Helsinki.

Red Redhouse (2008): The Larger Redhouse Portable Dictionary. English-Turkish Turkish-English. İstanbul.

refl. reflexive

Ro00 Roos, M. (2000): The Western Yugur (Yellow Uygur) Language. Grammar, Texts, Vocabulary. Unpublished dissertation (Proefschrift ter verkrijging van de graad van Doctor aan de Rijksuniversiteit te Leiden).

Rö Röhrborn, K. (1977ff.): Uigurisches Wörterbuch. Wiesbaden.

$\mathrm{Ru} . \quad$ Russian

Ry06 Rybatzki, V. (2006): Die Personennamen und Titel der mittelmongolischen Dokumente. Eine lexikalische Untersuchung. Helsinki (Publications of the Institute for Asian and African Studies 8).

$\mathrm{Sal} / \mathrm{Ili} \quad$ Salar from the Ili region

$\mathrm{Sal} / \mathrm{Qh} \quad$ Salar from Qinghai

s. $\quad$ suffix

$\mathrm{S} \quad=\mathrm{MMoS}$

SC South-Central

Sch92 Schwarz, H. G. (1992): An Uyghur-English Dictionary. Bellingham.

SE South-East

Sgl. Sanglechi

SH "Secret History of the Mongols"

Sh76 Shaw, R. B. (1876): On the Ghalchah Languages [Waxi and Sariqoli]. [Separate, unchanged reprint of an article published also in the Journal of the Asiatic Society of Bengal Vol. 45, No. 1, pp. 139-278].

Shn66 Shnitnikov, B. N. (1966): Kazakh-English Dictionary. London-The Hague-Paris s.i.a.m.l.g. similar in all main language groups 
Sib.

Sibe

$\mathrm{Sib} / \mathrm{Ili} \quad$ Sibe from the Ili region

s.i.m.m.l.g. similar in many main language groups

s.i.s.m.l. similar in some main languages

Skt. Sanskrit

Srq. $\quad$ Sariqoli

St Steingass, F. J. (1892): A Comprehensive Persian-English Dictionary, Including the Arabic Words and Phrases to be Met with in Persian Literature. London.

StachK08 Stachowski, K. (2008): Names of Cereals in the Turkic Languages. Kraków (Studia Turcologica Cracoviensia 11).

St-Ka99 Steblin-Kamenskiū, I. M. (1999): Etimologiceskiŭ slovarb vaxanskogo jazyka - Etymological Dictionary of the Wakhi Language. St. Petersburg.

SW South-West

syn. Synonym

Š $\quad$ Šruni

T Turner, Sir R. L. (1962-1966): A Comparative Dictionary of Indo-Aryan Languages. London.

Taj. Tajik

Tat. Tatar

Ten76a Tenišev, E. R. (1976a): Stroĭ saryg-jugurskogo jazyka. Moskva.

Ten76b Tenišev, E. R. (1976b): Strǒ salarskogo jazyka. Moskva.

Tib. Tibetan

TMEN Doerfer, G. (1963/1965/1967/1975): Türkische und mongolische Elemente im Neupersischen I-IV. Wiesbaden.

tr. translate/s

Tr. Turkish (Turkic language of Turkey)

Trki Turki (= Otü., Uy $\gamma$.)

Trki/Ili Turki spoken in the Ili region

Trkm. Turkmen

Trkm/Afgh Turkmen from Afghanistan

Trkm/Khiva Turkmen spoken in Khiva

Tu. Turkic

Tung. Tungusic

Tuv. Tuvinian

$\mathrm{U} \quad=\mathrm{MMoU}$

Uig. (Old) Uighur

Urd. Urdu

Uy $\quad$ (Modern) Uyghur (= Otü., Trki)

v. verb

VEWT Räsänen, M. (1969): Versuch eines etymologischen Wörterbuchs der Türksprachen. Helsinki (Lexica Societatis Fenno-Ugricae Vol. XVII, No. 1).

vs. versus

w. with

Wai. Waigali 
Wx. Waxi

W71 Weiers, M. (1971): Das Moghol-Vokabular von W. R. H. Merk. Zentralasiatische Studien Vol. 5, pp. 157-189.

W72a Weiers, M. (1972a): Die Sprache der Moghol der Provinz Herat in Afghanistan. Materialien zur Sprache und Literatur der Mongolen von Afghanistan, I. Opladen (Abhandlungen der Rheinisch-Westfälischen Akademie der Wissenschaften 49).

W72b Weiers, M. (1972b): Bericht über weitere Arbeiten bei den Moghol von Afghanistan, 1971. Zentralasiatische Studien Vol. 6, pp. 575-584.

W73 Weiers, M. (1973): Eine fünfsprachige Wørtersammlung aus dem Gebiet der Moghol von Herat in Afghanistan. Zentralasiatische Studien Vol. 7, pp. 503-523.

W75a Weiers, M. (1975a): Schriftliche Quellen in Mogolī. 2. Teil: Bearbeitung der Texte. Materialien zur Sprache und Literatur der Mongolen von Afghanistan, III. Opladen (Abhandlungen der Rheinisch-Westfälischen Akademie der Wissenschaften 59).

W75b Weiers, M. (1975b): Die Sprache der Hazara und der Mongolen von Afghanistan in lexikostatistischer Sicht. Afghanistan Journal Vols 2-3, pp. 98-102.

W77 Weiers, M. (1977): Schriftliche Quellen in Mogolī. 3. Teil: Poesie der Mogholen. Materialien zur Sprache und Literatur der Mongolen von Afghanistan, IV. Opladen (Abhandlungen der Rheinisch-Westfälischen Akademie der Wissenschaften 62).

W83 Weiers, M. (1982-1983): Aus der Poesie der Mogholen. AOH Vol. 36, pp. 563-574.

Yagh. Yaghnobi

Yak. Yakut

Ya02 Yakup, A. (2002): An Ili-Salar Vocabulary. Tokyo (CSEL Series 5).

Yd. Yidya

YogE Eastern Yogur (Mongolic)

YogW Western Yogur (Turkic)

zool. $\quad$ zoological $\|>$ borrowed into

$>\quad$ borrowed into

$<\quad$ borrowed from

$<>\quad$ direction of borrowing uncertain

$\rightarrow \quad$ (i) development, derivation into; (ii) look further in same entry

$\leftarrow \quad$ (i) development, derivation from; (ii) look below in same entry

$\uparrow \quad$ look above in different entry

$\downarrow \quad$ look below in different entry

/ or; after Tu., Mo. indicating language; after languages indicating dialects

$=\quad$ same as

$\sim \quad$ similar/equivalent to

$\approx \quad$ somehow similar/equivalent to

$\neq \quad$ not the same as, different from

$\dagger \quad$ ghostword, unattested word

? questionable

* $\quad$ reconstructed form

$\varnothing \quad$ no occurrence/s 


\section{References}

Badghisi, Shah Abdullah (1960): Dictionary of Some Languages and Dialects of Afghanistan. Washington (Journal of Indo-European Studies, Monograph number 48).

Bailey, H. W. (1946): Ghāndārī. Bulletin of the School of Oriental and African Studies Vol. 11, pp. $764-797$.

Bailey, H. W. (1979): Dictionary of Khotan Saka. Cambridge.

Baskakov, N. A. (1992): Titres et grades dans la structure sociale de l'ancien khanat de Khiva. In: Bacqué-Grammont, J.-L. - Dor, R. (eds): Mélanges offerts à Louis Bazin par ses disciples, collègues et amis. Paris (Varia Turcica XIX), pp. 293-298.

Benveniste, E. (1955): Un lexique du yagnobi. JA Vol. 243, pp. 139-162.

Berta, Á. (1996): Deverbale Wortbildung im Mittelkiptschakisch-Türkischen. Wiesbaden (Turcologica 24).

Boyce, M. (1977): A Word-list in Manichaen Middle Persian and Parthian. Leiden (Acta Iranica 9a).

Buell, P. D. (1990): Pleasing the Palate of the Qan: Changing Foodways of the Imperial Mongols. Mongolian Studies Vol. XIII, pp. 57-81.

Buell, P. D. (1999): Mongol Empire and Turkicization - The Evidence of Food and Foodways. In: Amitai-Preiss, R.-D. O. Morgan (eds): The Mongol Empire and its Legacy. Leiden, pp. $200-223$.

Buell, P. D. - Anderson, E. N. (2010): A Soup for the Qan - Chinese Dietary Medicine of the Mongol Era as Seen in Hu Szu-hui's Yin-shan Cheng-yao. New York.

Castrén, A. M. (1856): Grundzüge einer tungusischen Sprachlehre, nebst kurzem Wörterverzeichniss. St. Petersburg.

Clark, L. V. (1977): Mongol Elements in Old Turkic? Journale de la Société Finno-ougrienne Vol. 75 , pp. $110-167$.

Cleaves, F. W. (1949): The Sino-Mongolian Inscription of 1362 in Memory of Prince Hindu. Harvard Journal of Asiatic Studies Vol. 12, pp. 1-133.

Doerfer, G. (1965): Zur Schreibung des auslautenden $o$ der mongolischen Schriftsprache. Central Asiatic Journal Vol. 10, pp. 55-60.

Doerfer, G. (1971): Irano-Altaistica - Turkish and Mongolian Languages of Persia and Afghanistan. Current Trends in Linguistics Vol. 6, pp. 217-234.

Doerfer, G. (1974): Zu mongolisch «keyenüwe». $A O H$ Vol. 28, pp. 99-110.

Doerfer, G. (1992): Mongolica im Alttürkischen. In: Stalph, J.-Hijiya-Kirschnereit, I. (eds): Bruno Lewin zu Ehren. Festschrift aus Anlaß seines 65. Geburtstag. Band III: Koreanische und andere asienwissenschaftliche Beiträge. Bochum, pp. 39-56.

Doerfer, G. (1993): The Older Mongolian Layer in Ancient Turkic. In: Ölmez, Mehmet (ed.): Festschrift für Talat Tekin. Istanbul (Türk Dilleri Araştırmaları 3), pp. 79-86.

Doerfer, G. (2004): Etymologisch-ethnologisches Wörterbuch tungusischer Dialekte (vornehmlich der Mandschurei). Unter Mitwirkung von Michael Knüppel. Hildesheim-Zürich-New York.

Drimba, V. (1976): Remarques sur les mots d'emprunt mongols de la langue salare. Revue roumaine de linguistique Vol. 21, pp. 417-427.

Dupree, L. (1973): Afghanistan. Princeton, New Jersey.

Durkin-Meisterernst, D. (2004): Dictionary of Manichaean Texts, Vol. III: Texts from Central Asia and China. Edited by Nicholas Sims-Williams. Turnhout (Corpus Fontium Manichaeorum).

Dzagdsüren, U. - Tsolo, J. (1982): Khan Siir. A Chapter of the Jangar Epic. AOH Vol. 36, pp. $271-$ 314. 
Erdal, M. (1991): Old Turkic Word Formation I-II. Wiesbaden (Turcologica 7).

Eren, H. (1999): Türk dilinin etimolojik sözlüğ̈̈. Ankara.

Golden, P. B. (1991): The Dogs of the Medieval Qïpčaqs. In: Varia Eurasiatica. Festschrift für Professor András Róna-Tas. Szeged, pp. 45-56.

Golden, P. B. (2001): The Terminology of Slavery and Servitude in Medieval Turkic. In: DeWeese, D. (ed.): Studies on Central Asian History in Honor of Yuri Bregel. Bloomington (Indiana University Uralic and Altaic Series 167), pp. 27-56.

Grønbech, K. (1942): Komanisches Wörterbuch. Kopenhagen (Monumenta Linguarum Asiæ Maioris).

Grube, W. (1900): Goldisch-Deutsches Wörterverzeichnis. In: Schrenck, L. von (ed.): Reisen und Forschungen im Amur-Land. Anhang zum 3. Band. St. Petersburg.

Halén, H. (1978): Westlamutische Materialien. Aufgezeichnet von Arvo Sotavalta, bearbeitet und herausgegeben von Harry Halén. Helsinki (Mémoires de la Société Finno-ougrienne 168).

Hauenschild, I. (1993): Krimtatarische Pflanzennamen. Ural-altaische Jahrbücher NF Vol. 12, pp. $147-178$.

Hauenschild, I. (1994): Botanica im Dîwân lugiât at-turk. Journal of Turcology Vol. 2, No. 1, pp. $25-100$.

Hauenschild, I. (1996): Tiermetaphorik in türksprachigen Pflanzennamen. Wiesbaden (Turcologica 29).

Hauenschild, I. (1998): Krimtatarische Tierbezeichnungen. Orientalia Suecana Vol. 47, pp. 29-54.

Hauenschild, I. (2003): Die Tierbezeichnungen bei Mahmud al-Kaschgari - Eine Untersuchung aus sprach- und kulturhistorischer Sicht. Wiesbaden (Turcologica 53).

Hauenschild, I. (2006): Botanica und Zoologica im Babur-name. Eine lexikologische und kulturhistorische Untersuchung. (Turcologica 66.) Wiesbaden.

Hauenschild, I. (2008): Lexikon jakutischer Tierbezeichnungen. Wiesbaden (Turcologica 77).

Hauer, E. (2007): Handwörterbuch der Mandschusprache 2. durchgesehene und erweiterte Auflage herausgegeben von Oliver Corff. Wiesbaden.

Houtsma, M. Th. (1894): Ein türkisch-arabisches Glossar. Leiden.

Iwamura, Sh.-Schurmann, H. F. (1954): Notes on Mongolian Groups in Afghanistan. In: Silver Anniversary Volume of Zinbun-Kagaku-Kenkyu-syo. Kyoto, pp. 480-515.

Janhunen, J. (1996): Prolegomena to a Comparative Analysis of Mongolic and Tungusic. In: Stary, G. (ed.): Proceedings of the 38th Permanent International Altaistic Conference (PIAC), Kawasaki, Japan: August 7-12, 1995. Wiesbaden, pp. 209-218.

Janhunen, J. (1998): The Horse in East Asia: Reviewing the Linguistic Evidence. In: Mair, V. H. (ed.): The Bronze Age and Early Iron Age Peoples of Eastern Central Asia. Washington D.C. (Journal of Indo-European Studies, Monograph No. 26), pp. 415-430.

Joki, A. J. (1952): Die Lehnwörter des Sajansamojedischen. Helsinki (Mémoires de la Société Finno-ougrienne 103).

Kałużyński, S. (1961): Mongolische Elemente in der jakutischen Sprache. Warschau.

Kałużyński, S. (1971a-b.): Solonisches Wörterverzeichnis I-II. Rocznik Orientalistyczny Vol. 34, No. 1, pp. 39-79; Vol. 34, No. 2, pp. 15-56.

Kałużyński, S. (1977): Die Sprache des mandschurischen Stammes Sibe aus der Gegend von Kuldscha. Warschau.

Kałużyński, S. (1995): Iacutica, prace jakutoznawcze. Warszawa (Philologia Orientalis 2).

Kane, D. (1989): The Sino-Jurchen Vocabulary of the Bureau of Interpreters. Bloomington (Indiana University Uralic and Altaic Series 153).

Kane, D. (2009): The Kitan Language and Script. Leiden-Boston (Handbuch der Orientalistik VIII/19). 
Kara, Gy. (1991): Jurchen Notes [Review: Kane 1989]. AOH Vol. 45, pp. 149-158.

Kempf, B. (2012): Semantical Categories of Turkic Elements in Kalmyk. In: Birtalan, Á. (ed.): Oirad and Kalmyk Linguistic Essays. Budapest, pp. 134-162.

Khabtagaeva, B. (2001): Colour Names and their Suffixes - A Study on the History of Mongolian Word Formation. $A O H$ Vol. 54, pp. 85-165.

Khabtagaeva, B. (2009): Mongolic Elements in Tuvan. Wiesbaden (Turcologica 81).

Konow, S. (1949): Primer of Khotanese Saka. Oslo.

Kúnos, I. (1902): Šejx Sulejman Efendis Čagataj-Osmanisches Wörterbuch. Budapest (A magyar néprajzi társaság keleti szakosztályának kiadványai I.).

Laude-Cirtautas, I. (1961): Der Gebrauch der Farbbezeichnungen in den Türksprachen. Wiesbaden.

Laufer, B. (1916): Loan-words in Tibetan. T'oung Pao Vol. 17, pp. 403-552.

Ligeti, L. (1964): Les fragments du subhâșitaratnanidhi mongol en écriture 'hPags-pa. Le mongol préclassique et le moyen mongol. $A O H$ Vol. 17, pp. 239-292.

Ma Quanlin-Ma Wanxiang - Ma Zhicheng (1993): Salar Language Materials. Philadelphia (SinoPlatonic Papers 43).

MacKenzie, D. N. (1971): A Concise Pahlavi Dictionary. New York-Toronto.

Mannerheim, C. G. E. (1911): A Visit to the Sarö and Shera Yögurs. JSFOu Vol. 26, pp. 1-72.

Mayrhofer, M. (1960): Mongolische Pferdewörter bei einem Sanskrit-Lexikographen? Paideuma Vol. 7, Nos 4-6, pp. 274-276.

Menges, K. (1935): Die Wörter für 'Kamel' und einige seiner Kreuzungsformen im Türkischen. UJb Vol. 15, pp. 517-528.

Menges, K. (1971): Zu einigen Charakteristika des gesprochenen Manžu. CAJ Vol. 15, pp. 28 -54.

Morgenstierne, G. (1936): Iranian Elements in Khowar. Bulletin of the School of Asian Studies Vol. 8, pp. 657-671.

Morgenstierne, G. (1957): 'Mushroom' and 'Toadstool' in Indo-Iranian. Bulletin of the School of Asian and African Studies Vol. 20, pp. 451-457.

Nugteren, H. (1998): On Some Turkic Loanwords in Monguor, Bao'an and Dongxiang. In: Johanson, L. (ed.): The Mainz Meeting. Proceedings of the Seventh International Conference on Turkish Linguistics August 3-6, 1994. Wiesbaden, pp. 683-696.

Nyberg, H. S. (1974): A Manual of Pahlavi II. Wiesbaden.

Ölmez, M. (1998): Potanin's Yellow Uigur Material and its Importance Today. In: Stachowski, M. (ed.): Languages and Cultures of the Turkic Peoples. Kraków (Studia Turcologica Cracoviensia 5), pp. 148-184.

Ölmez, M. (2007): Tuwinischer Wortschatz mit alttürkischen und mongolischen Parallelen Tuvacanın Sözvarlı̆̆ Eski Türkçe ve Moğolca Denkleriyle. Wiesbaden (Veröffentlichungen der Societas Uralo-Altaica 72).

Pinault, G.-J. (1997): Terminologie du petit bétail en tokharien. Studia Etymologica Krakoviensia Vol. 2, pp. 175-218.

Poppe, N. N. (1954): Grammar of Written Mongolian. Wiesbaden (Porta Linguarum Orientalium NS 1).

Poppe, N. N. (1964): On Some Mongolian Names of Wild Beast. CAJ Vol. 9, pp. 161-174.

Poppe, N. N. (1966): On Some Ancient Mongolian Loan-words in Tungus. CAJ Vol. 11, pp. 187198.

Poppe, N. N. (1972): On some Mongolian Loan-words in Evenki. CAJ Vol. 16, pp. 95-103.

Róna-Tas, A. -†Á. Berta (with the assistance of László Károly) (2011): West Old Turkic - Turkic Loanwords in Hungarian i-ii. Wiesbaden (Turkologica 84). 
Rozycki, W. (1994): Mongol Elements in Manchu. Bloomington (Indiana University Uralic and Altaic Series 157).

Rybatzki, V. (1994): Bemerkungen zur türkischen und mongolischen Metallterminologie. Studia Orientalia (Helsinki) Vol. 73, pp. 193-251.

Rybatzki, V. (2003a): Middle Mongol. In: Janhunen, J. (ed.): The Mongolic Languages. London (Routledge Language Family Series 5), pp. 57-82.

Rybatzki, V. (2003b): Intra-Mongolic Taxonomy. In: Janhunen, J. (ed.): The Mongolic Languages. London (Routledge Language Family Series 5), pp. 364-390.

Rybatzki, V. (2009): Türkische Lehnwörter im Burushaski. In: Klaus Karttunen (ed.): Anantam śāstram. Indological and Linguistic Studies in Honour of Bertil Tikkanen. Helsinki (Studia Orientalia 108), pp. 149-179.

Rybatzki, V. (forthcoming 2017): Mongolic and Uyghur - A Lexical Study on the Relationship between Mongolic Languages and Modern Uyghur.

Rybatzki, V. (forthcoming b): An Etymological Dictionary of Middle Mongyol.

Schmidt, P. (1923): The Language of the Negidals. Acta Universitatis Latviensis Vol. 5, pp. 1-38.

Schmidt, P. (1927): The Language of the Oroches. Acta Universitatis Latviensis Vol. 7, pp. 17-62.

Schmidt, P. (1933): Chinesische Elemente im Mandschu, Teil 3. Asia Major Vol. 8, pp. 353-436.

Schönig, C. (2000): Mongolische Lehnwörter im Westoghusischen. Wiesbaden (Turcologica 47).

Schurmann, F. H. (1962): Mongols of Afganistan - An Ethnography of the Moghôls and Related Peoples of Afghanistan. 's-Gravenhage (Central Asiatic Studies IV).

Sevortjan, Ė. V. (1974ff.): Etimologičeskil slovarb tjurkskix jazykov i-vii. Leningrad.

Sköld, H. (1936): Materialien zu den Pamirsprachen. Lund-London-Paris-Oxford-Leipzig.

Smedt, A. de-A. Mostaert (1933): Dictionnaire Mongour-Français. Pei-p'ing.

Stachowski, M. (1993): Dolganischer Wortschatz. Kraków.

Stachowski, M. (1998): Dolganischer Wortschatz, Supplementband. Kraków.

Stachowski, M. (2007): Turkish dirsek 'elbow', Yakut tühürges 'knee' and Some Connected Words. In: Öztopçu, Kurtuluş (ed.): Festschrift in Honor of András J. E. Bodrogligeti. İstanbul (Türk Dilleri Araştırmaları 17), pp. 335-343.

Thomas, J. C. (2011): Zur Etymologie von Mongolisch noqai 'Hund' - Überlegungen zur Sippe

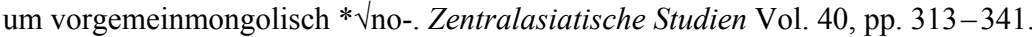

Tryjarski, E. (1979): The Dog in the Turkic Area - An Ethnolinguistic Study. CAJ Vol. 23, pp. $297-319$.

Vasmer, M. (1953/1955/1958): Russisches etymologisches Wörterbuch. I-III. Heidelberg.

Vovin, A. (2007a): Once Again on the Etymology of the Title qayan. Studia Etymologica Krakoviensia Vol. 12, pp. 177-187.

Vovin, A. (2007b): Once Again on the Tabgač Language. Mongolian Studies Vol. 24, pp. 191206.

Yamada, N. (1993): Sammlung uigurischer Kontrakte (1-3). Hrsg. J. Oda, P. Zieme, H. Umemura, T. Moriyasu. Osaka.

Yamamoto, K. (1969): A Classified Dictionary of Spoken Manchu. Tokyo.

Yin Tie-chao (1995): An Oroqen Glossary and Some of its Related Cultural Aspects. Linguistic and Oriental Studies from Poznań Vol. 2, pp. 189-212.

Zieme, P. (1992): Some Remarks on Old Turkish Words for "Wife". Türk Dili Araștıramlarl Yıllığı. Belleten 1987. Ankara, pp. 305-309. 